UNIVERSIDADE DE SÃO PAULO

ESCOLA DE EDUCAÇÃO FISICA E ESPORTE

OBJETIVOS ESPORTIVOS E OS CONFLITOS PSICOLÓGICOS EM NADADORES DE ELITE: A FENOMENOLOGIA COMO PROPOSTA DE INTERVENÇÃO MEDIANTE ESTUDO DE CASO

João Carlos Teixeira de Souza Barros

São Paulo

2005 


\title{
OBJETIVOS ESPORTIVOS E OS CONFLITOS PSICOLÓGICOS EM NADADORES DE ELITE: A FENOMENOLOGIA COMO PROPOSTA DE INTERVENÇÃO MEDIANTE ESTUDO DE CASO
}

JOÃO CARLOS TEIXEIRA DE SOUZA BARROS

\begin{abstract}
Dissertação apresentada à Escola de Educação Física e Esporte da Universidade de São Paulo, como requisito parcial para obtenção do grau de Mestre em Educação Física
\end{abstract}

ORIENTADOR: PROF. DR. DANTE DE ROSE JÚNIOR 


\section{Barros, João Carlos Teixeira de Souza}

Objetivos esportivos e os conflitos psicológicos em nadadores de elite: a fenomenologia como proposta de intervenção mediante estudo de caso / João Carlos Teixeira de Souza Barros. - São Paulo : [s.n.], 2005.. xvi, 94p.

Dissertação (Mestrado) - -Escola de Educação Física e Esporte da Universidade de São Paulo.

Orientador: Prof. Dr. Dante de Rose Junior

1. Psicologia do esporte 2. Natação I. Título. 


\section{AGRADECIMENTOS}

Este trabalho é fruto do convivio agradável com muitas pessoas. Incontáveis. O ambiente esportivo tem dessas coisas. Ao citar o Prof. Dr. Dante de Rose Júnior, mais que um orientador, os amigos da Escola de Educação Física e Esporte da USP, Grupo de Estudos e Pesquisa em Psicologia do Esporte GEPPE/EEFE/USP, da Confederação Brasileira de Desportos Aquáticos - CBDA e da Universidade Santa Cecília - UNISANTA, em especial, me reporto e agradeço a todos que forma direta ou indireta colaboraram com esse estudo.

Aos nadadores que, de há muito, vêm colaborando com o meu aprendizado, também um agradecimento especial. A turma do Inter é inesquecivel.

Ao Pedro, Canadá, Luciana, Leonardo, Ricardo, Mariana e Lucas, Barros e Bentos, pela companhia compreensiva e inspiradora.

Dedicatória

Ao velho homem do mar aonde quer que estejas navegando 
SUMÁRIO

Páginas

LISTA DE TABELAS ................................................................ vi

LISTA DE FGURAS ….............................................................. vii

LISTA DE QUADROS …............................................................ ix

LISTA DE ANEXOS ......................................................................

SIGLAS E ABREVIAÇÕES .........................................................

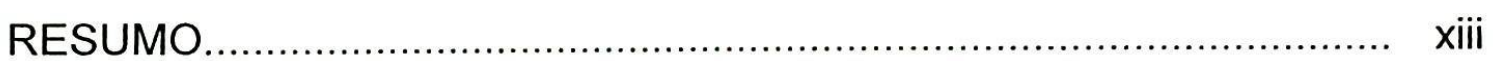

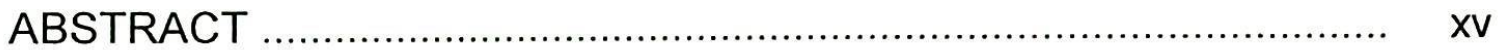

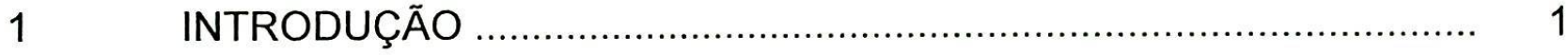

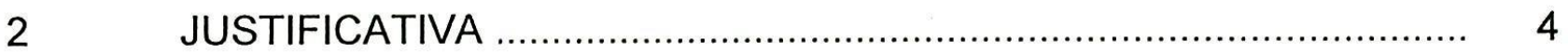

$2.1 \quad$ O processo de intervenção ............................................................ 5

2.2 A prática da intervenção …………….............................................. 5

3 QUESTÕES QUE ORIENTAM O ESTUDO ….................................. 6

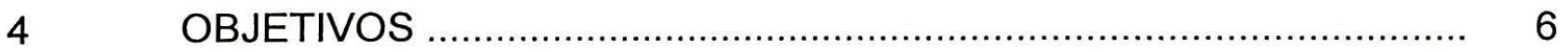

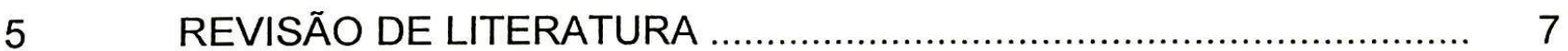

5.1 O esporte competitivo de alta performance ......................................... 7

5.2 A natação como modalidade competitiva de alta performances ........... 8

5.3 Aspectos psicológicos e o ambiente de alta performance ................... 10

5.4 Objetivos Esportivos: complexidade e implicações psicológicas nos programas de treinamentos e nas performances competitivas ............. 13

5.5 Conflitos e crises psicológicas relacionadas aos objetivos esportivos ... 18

5.6 A síndrome de objetivos esportivos com projeções retroativas ............ 20

5.7 A pesquisa fenomenológica na psicologia esportiva ......................... 26 
5.7.1 A redução fenomenológica e as análises interpretativas das entrevistas

5.7.2 O método fenomenológico na investigação das vivências no campo esportivo

5.7.3 Pesquisa em psicologia fenomenológica no campo esportivo

5.8 A entrevista psicológica

5.8.1 A entrevista psicológica como campo de atuação 33

5.8.2 A experiência no campo esportivo e a entrevista psicológica com abordagem fenomenológica

6.1 Caracterização da pesquisa .............................................................. 35

6.2 Sujeito da pesquisa: um estudo de caso ............................................ 36

6.3 Instrumentos ............................................................................... 37

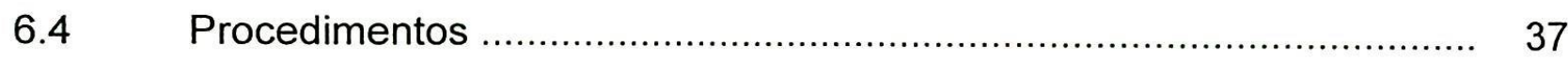

6.4.1 Obtenção do histórico esportivo ......................................... 38

6.4.2 Observação sistemática nos treinamentos e nas competições .................................................................. 38

6.4.3 Entrevistas de diagnóstico e intervenções psicológicas

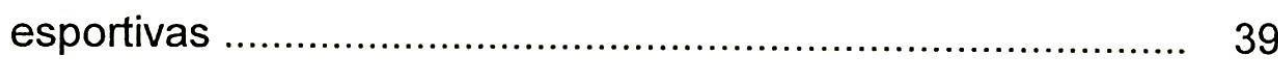

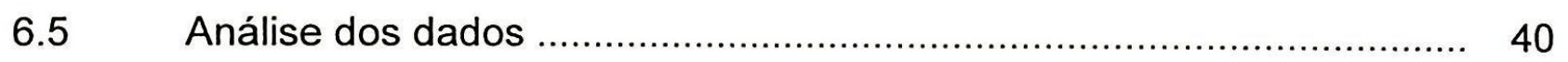

7 RESULTADOS: APRESENTAÇÃO E DISCUSSÃO .......................... 42

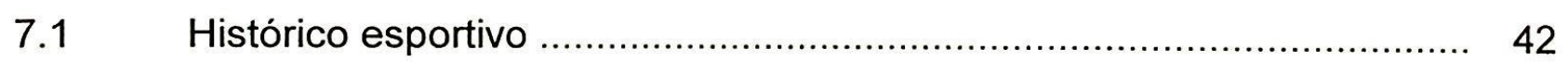

7.2 Observação sistemática nos treinamentos e nas competições ............. 56

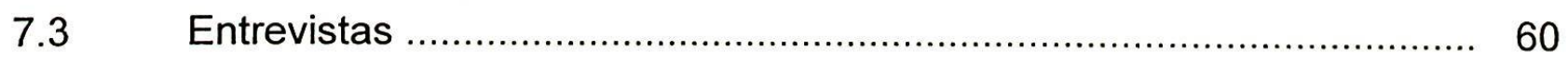

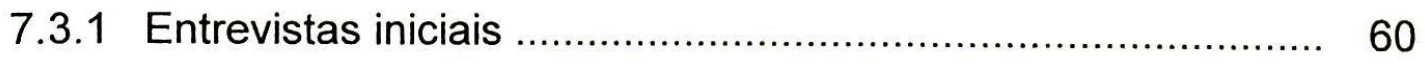

7.3.2 Entrevistas psicológicas e identificação dos conflitos de objetivos esportivos .......................................................... 61

7.3.3 Análise e interpretação dos discursos .................................. 61 
7.3.4 Intervenções psicológicas referentes às questões desveladas e a Fase $D$ do período pós-interventivo ............. 67

7.3.5 A apreensão e compreensão: o processo de interação ........ 76 PERSPECTIVAS CONCLUSIVAS 79 


\section{LISTA DE TABELAS}

TABELA 1 - Participações em campeonatos oficiais em piscinas de 50 metros na prova dos 100 metros nado Peito no período compreendido entre 1999 e 2003 ...........................................

TABELA 2 - Demonstrativo dos tempos obtidos e médias por temporada esportivas que situam o estudo para as análises técnicas qualitativas

TABELA 3-Análise de desempenho técnico das Fases $A, B$, e $C$ do período pré-interventivo

TABELA 4 - Análise de desempenho técnico da Fase A do período préinterventivo

TABELA 5 - Performances da Fase A consideradas estabilizadas

TABELA 6 - Performance da Fase A considerada piorada

TABELA 7 - Performance da Fase A consideradas melhoradas

TABELA 8 - Demonstrativo de melhoras de performances da Fase A para a Fase B

TABELA 9 - Análise de desempenho técnico da Fase B do período préinterventivo

TABELA 10 - Demonstrativo dos ganhos qualitativos do resultado da Fase $B$ em relação ao melhor tempo da Fase $A$

TABELA 11 - Demonstrativo dos ganhos qualitativos dos resultados da Fase $D$ em relação ao melhor tempo da Fase $B$ 


\section{LISTA DE FIGURAS}

FIGURA 1 - Demonstrativo de comportamento resultante do foco esportivo centrado em projeções futuras e passadas

FIGURA 2 - Tempos registrados na distância dos 100 metros nado Peito na temporada esportiva do ano 1999 em eventos oficiais disputados em piscinas de 50 metros

FIGURA 3 - Tempos registrados na distância dos 100 metros nado Peito em eventos oficiais no ano de 2000 em piscinas de 50 metros

FIGURA 4 - Tempos registrados na distância dos 100 metros nado Peito em eventos oficiais no ano de 2001 em piscinas de 50 metros

FIGURA 5 - Tempos registrados na distância dos 100 metros nado Peito em eventos oficiais no ano de 2002 em piscinas de 50 metros

FIGURA 6 - Oscilações de tempos entre os melhores e os piores resultados por temporadas esportivas

FIGURA 7 - Tempos obtidos nos 100 metros nado Peito no período préinterventivos

FIGURA 8 - Demonstrativo de melhora, estabilidade e piora de performance na prova dos 100 metros nado Peito na Fase $\mathrm{A}$ do período pré-interventivo

FIGURA 9 - Demonstrativo das melhoras de tempos das Fases A e B.....

FIGURA 10 - Comparativo qualitativo das Fases A e B.

FIGURA 11 - Representação da melhora de desempenho nas participações $7^{\mathrm{a}}$. (B) e $9^{\mathrm{a}}$. (B) 
FIGURA 12 - Resultados competitivos da segunda metade da temporada de 2000 e temporadas completas de 2001 e 2002

FIGURA 13 - Comparativo qualitativo das Fases A, B e C pré-interventiva e Fase D pós-interventiva

FIGURA 14 - Representação das melhoras de desempenho nas participações da Fase D de números 17, 18, 19 e 20 


\section{LISTA DE QUADROS}

QUADRO 1 - Distâncias e nados oficiais para ambos os sexos percorridas em piscinas de 50 metros com recordes mundiais homologados pela FINA

QUADRO 2 - Exemplos de séries de treinamentos para melhora das capacidades técnicas e fisiológicas

QUADRO 3 - Exemplos de séries de treinamentos para melhora das capacidades técnicas e fisiológicas

QUADRO 4 - Exemplos de resultados de testes de lactacidemia das temporadas 2001, 2002 e 2003 durante os treinamentos

QUADRO 5 - Dados significativos das entrevistas diagnósticas psicológicas

QUADRO 6 - Dados significativos das entrevistas diagnósticas psicológicas referentes à Fase $\mathrm{C}$ que evidenciam conflitos de objetivos e de identidade esportiva

QUADRO 7 - Exemplos de alguns dados significativos das entrevistas psicológicas referentes à Fase $\mathrm{D}$ que evidenciam o processo de interação e o resignificado dos conflitos de objetivos e reorganização da identidade esportiva

QUADRO 8 - Exemplos de alguns dados significativos das entrevistas psicológicas referentes à Fase $D$ que evidenciam a compreensão dos fatos esportivos conflituosos vivenciados

QUADRO 9 - Exemplos de dados significativos das entrevistas psicológicas referentes à Fase $\mathrm{D}$ que evidenciam a transição compreensiva da nadadora 
QUADRO 10- Exemplos de dados significativos das entrevistas psicológicas referentes à compreensão de todo o processo de intervenção 


\section{LISTA DE ANEXOS}

ANEXO I - Parecer do Comitê de Ética ..................................................... 93

ANEXO II - Termo de consentimento livre e informado à atleta .................. 94 


\section{SIGLAS E ABREVIAÇÕES}

FINA …......... Federação Internacional de Natação

CBDA …....... Confederação Brasileira de Desportos Aquáticos

FAP ............... Federação Aquática Paulista

CT ............... Comissão Técnica

OE ............... Objetivos Esportivos

OER …......... Objetivos Esportivos de Resultado

OEX ............. Objetivos Esportivos de Execução

SOERP ........ Síndrome de Objetivos Esportivos com Projeções Retroativas 


\title{
RESUMO
}

\section{OBJETIVOS ESPORTIVOS E OS CONFLITOS PSICOLÓGICOS EM NADADORES DE ELITE: A FENOMENOLOGIA COMO PROPOSTA DE INTERVENÇÃO MEDIANTE UM ESTUDO DE CASO}

\author{
Autor: JOÃO CARLOS TEIXEIRA DE SOUZA BARROS \\ Orientador: Prof. Dr. DANTE DE ROSE JÚNIOR
}

A proposta deste estudo foi investigar a viabilidade da utilização de uma conduta de diagnóstico e intervenção psicológica esportiva em uma nadadora de alto nível técnico que apresentava, sem motivos aparentes, conflitos relacionados aos objetivos esportivos após obtenção de um resultado técnico expressivo. A atleta não conseguia ultrapassar a sua melhor marca, embora viesse apresentando bons rendimento nas sessões de treinamento, por mais de duas e meia temporadas esportivas. A nadadora apresentava apatia competitiva não condizentes com o seu histórico atlético. Para a realização deste estudo de caso, a fundamentação da fenomenologia existencial, transposta da filosofia para a psicologia, mostrou ser um eficiente suporte para a escuta e o ordenamento da compreensão das experiências vivenciais da atleta à medida em que elas foram se sucedendo. A tentativa de permanência em situações psicologicamente significativas, resultantes de momentos especiais, como se caracterizam os grandes resultados dos esportes competitivos, podem aprisionar e bloquear o desenvolvimento e até a continuidade da prática 
esportiva em altas performances. Nesse estudo se caracterizou tais atitudes psicológicas como síndrome de objetivos esportivos com projeções retroativas. As proposições que procuram por uma ampliação dos caminhos interpretativos dentro da psicologia voltada para o esporte objetivando a compreensão de atletas e a instigação fenomenológica demonstraram ser possiveis no campo esportivo como uma atitude que envolve a centralização na pessoa existente e enfatiza o ser humano como emergente e em evolução. Os resultados indicam que os objetivos esportivos devem ser constantemente observados e reordenados ao longo do desenvolvimento das carreiras esportivas, para que ocorra a consonância das variáveis técnicas, físicas, táticas e psicológicas que compõem os programas de treinamentos e, principalmente, o momento competitivo. Com a compreensão do despedir-se dos resultados significativos obtidos, a nadadora demonstrou possibilidades motivacionais ampliadas para novas aquisições.

Palavras-chave: psicologia do esporte; fenomenologia; natação; performance; conflitos. 


\begin{abstract}
SPORT GOALS AND PSYCHOLOGICAL CONFLICTS IN ELITE SWIMMERS: THE PHENOMENOLOGY AS INTERVENTION PROPOSAL BY MEANS OF A CASE STUDY
\end{abstract}

\author{
Author: JOÃO CARLOS TEIXEIRA DE SOUZA BARROS \\ Adviser: Prof. Dr. DANTE DE ROSE JÚNIOR
}

The proposal of this study was to investigate the use of a diagnostic form and sports psychological intervention in a high level female swimmer who showed, for no apparent reason, conflicts related to the sport goals after a significant technical result. The athlete could not break her own record, although she had had good performance in training sessions for two and half seasons. The swimmer showed competitive apathy, which was not suitable for her athletic background. To accomplish this case of study, the basis of the existential phenomenology, transferred from philosophy to psychology, was found to be an effective support for the understanding and comprehension of the experiences gone through the athlete as they occurred. The attempt to remain in psychologically significant situations from special moments, as great results from the competitive sports are characterized, can seize and block the development and even the continuity of the sport practice in high level performances. In this study such psychological attitudes were characterized as sports goals syndrome with retroactive projections. The propositions that look for further interpretative ways within sports psychology aiming at the understanding of athletes and the phenomenological provocation showed to be possible in the sports area as an attitude that involves the centralization in the existing person and emphasizes the 
human being as emergent and in evolution. The results showed that the sports goals must be constantly observed and reorganized along the development of the sports carrier in order to occur the conformity of the technical, physical, tactical and psychological variables that form the training programs, and mainly the competitive moments. By the comprehension of saying goodbye to significant results, the swimmer showed motivational possibilities taken to new achievements.

Key words: sport psychology; phenomenology; swimming; performance; conflicts. 


\section{INTRODUÇÃO}

Atuar no esporte de alto rendimento significa, nos dias de hoje, adentrar no mundo das ciências aplicadas pela busca da mais alta eficácia psicofisiológica humana. O fenômeno denominado esporte moderno, tem, na alta competição, um forte apelo de entretenimento cujo aporte de recursos econômicos, pela busca da superação dos recordes, requer um respaldo técnico especializado para a compreensão dos limites do homem nessas atividades, garantindo, dessa forma, o retorno não só dos investimentos, mas de todo um contexto espectável.

Anseios de todas as ordens cercam os grandes eventos esportivos, gerando, como conseqüência das performances ${ }^{1}$ dos atletas, altos niveis de satisfação aos vitoriosos e frustração aos perdedores.

Essa bipolaridade comportamental, por vezes paralisa nações que elegem e depositam nos seus representantes reações emocionais das mais diversas, tal a envolvência dessa manifestação chamada esporte.

A psicologia, ciência que busca a compreensão das ações humanas, encontra no ambiente esportivo uma ampla possibilidade de leituras para o entendimento do homem atleta, envolvido com os seus limites psicofisiológicos.

Dentre as atividades classificadas como olímpicas, cuja representação nessas ocasiões simboliza o esplendor das performances, figura a natação. Atividade cíclica com histórico apelo competitivo, permite que indivíduos, muito jovens, iniciemse em disputas, ainda nos primeiros momentos do aperfeiçoamento das braçadas.

Nas competições de natação, em seus mais diferentes níveis técnicos, ficam evidentes várias manifestações emocionais relacionadas com a atividade competitiva, tanto pelos praticantes; como também por parte de todos aqueles que compõem o ambiente competitivo aquático desportivo, formado pelas torcidas, pais, dirigentes, torcedores, imprensa, patrocinadores, dentre outros.

A competição esportiva mobiliza os aspectos psíquicos dos indivíduos, podendo os niveis de ansiedade e estresse, quando ultrapassam os limiares do controle, ultrapassarem os limiares do equilibrio e interferir não somente nos 
resultados esportivos, como também na saúde mental dos praticantes, independentemente do seu nivel técnico e faixa etária.

O esporte tem na competição um momento único, para o qual os atletas são preparados por anos sob abstinências diversas, buscando, nos resultados dos seus desempenhos, vivenciar intensamente os momentos de glória. Persistentes, retornam por vezes, na tentativa da obtenção dos louros destinados aos vencedores. Muitos esmorecem ao longo da árdua trajetória, sem compreender as reais razões que motivam as interrupções das suas práticas, nesse restrito seguimento de excelências.

As emoções humanas, instância de difícil acesso e compreensão, vêm despertando considerável interesse no campo da pesquisa esportiva, uma vez que a mídia mostra, em tempos reais, ações e reações das mais diversas, quando, na autenticidade do jogo, ficam evidentes respostas psicológicas de todas as ordens.

Dentre as variáveis que compõem as performances esportivas, compete à psicologia observar e compreender o comportamento, agregando-se de forma autêntica e legítima às demais ciências, como bioquímica e biomecânica, responsáveis pelas qualidades energéticas e pelos gestos técnicos, nessa ordem.

Longe ainda de uma compreensão prática plena, tal noviciado desse seguimento científico em nosso país, a psicologia esportiva desperta como uma das últimas disciplinas a ser incorporada nas especialidades que assessoram os programas de treinamento, desde a formação dos atletas até as suas mais altas exigências da prática esportiva.

Competente ao seu papel, está uma das mais árduas tarefas dos programas de preparação esportiva: analisar e clarear o quanto de realidade existe nos Objetivos Esportivos (OE) propostos pelos atletas e técnicos.

Estipular metas esportivas reais talvez seja um dos aspectos mais complexos para os psicólogos esportivos junto às Comissões Técnicas (CT) e à figura principal do ambiente: o atleta. O objetivo esportivo, ao contrário de ser ponto

\footnotetext{
1 “Performance é uma expressão de origem francesa, adotada e difundida na língua inglesa para indicar a realização eficaz e perfeita de uma habilidade desportiva ou de uma ação de jogo" (GRANELL \& CERVERA, 2003, p. 9).
} 
de chegada é ponto de partida, modulando, já no primeiro momento da sua estipulação, o comportamento do praticante e a estratégia de ação da CT.

Que razões e motivos levam indivíduos a se submeterem às altas cargas de intensidades diversas por anos a fio, em busca de destaque dentre os seus pares? Quais os "para quês" justificam as razões psicológicas do homem junto aos seus limites no ambiente das altas performances?

Trazer à luz da compreensão os fenômenos psíquicos da individualidade humana, requer um exercício de igual rigor tanto para o psicólogo como para os demais colegas especialistas que conjugam na construção de novos paradigmas que possam aproximar o desportista da sua realidade competitiva.

Buscar por algumas das respostas que evidenciem a singularidade psíquica dos nadadores no ambiente de alta competição, cujas resultantes podem interferir tanto de forma positiva como negativa nas performances, bem como na continuidade da prática e na qualidade da saúde dos praticantes, motivam esse trabalho de pesquisa no campo da psicologia voltada ao esporte.

Consciente, conforme CRITELLI (1996, p. 25) de que "não se sai em busca da compreensão de um fenômeno tentando aplicar sobre ele uma mesma resposta já sabida sobre o mesmo", procurar-se-á apreender as vivências do indivíduo, mediante descrições, bem como suas projeções passadas, presentes e futuras, suas expectativas e toda a sua realidade em relação aos seus objetivos esportivos. Esta proposta de investigação é motivada e sabedora de que a escolha de um problema para estudos provém de grupos, comunidades e tradições nas quais o pesquisador também se move, onde por certo há questões a serem preenchidas (RUNKEL \& McGRANTH, 1972). Essa curiosidade inquietante pela compreensão dos motivos e razões que suscitam as mais variadas, inesperadas, surpreendentes e não conclusivas reações humanas no campo, torna ainda mais fascinante o ambiente.

Para FEIJOO (2002), o pensamento expresso em palavras, pode ser um pensamento situado e preso às amarras da existência vivida. A psicologia, como ciência que interpreta as ações humanas, pode observa-las mediante várias abordagens e com os mais variados enfoques. Não significa, entretanto, ser menos sério, sem rigor ou metodológico. É um privilégio. 
E justamente na compreensão das vivências que se amalgamam o comportamento, necessitando, portanto, de clareamento de todos os obstáculos que possam impedir a continuidade do desenvolvimento pleno da pessoa humana.

Novos conceitos, novas abordagens, contradições, hesitações e métodos diversos, por certo, advirão, na busca do entendimento dos fenômenos comportamentais próprios dos esportistas. Com essas referências, dá-se início à pesquisa, convicto da sua amplitude, complexidade e também dos desafios que a cercam, bem como a certeza instigadora e motivacional ${ }^{2}$ de que ela não se esgotará.

O esporte competitivo de alta performance "per se" justifica-se em diferentes possibilidade de investigação, por envolver o indivíduo. $O$ homem é singular e inconcluso. Possui características próprias, não podendo igualar-se a nenhum outro da sua própria espécie plenamente. Quando inserido em um ambiente, responderá aos estímulos pertinentes ao meio de forma própria.

A busca das razões e motivos que caracterizam determinados comportamento quando o atleta está exposto às situações que potencializam ansiedade e estresse, justifica um olhar mais atento por parte daqueles que conduzem os programas esportivos.

O olhar singular e qualitativamente analisado, poderá trazer à luz uma série de conhecimentos com relação aos aspectos psicológicos dos esportistas, colaborando para uma compreensão ampliada sobre o ambiente competitivo, bem como sobre as reações dos praticantes nesse mesmo ambiente.

Essa conduta é reforçada quando DAWAR e HORN (1992) afirmam que os investigadores deveriam abandonar a crença de que existe somente um caminho legítimo de conhecimento na psicologia esportiva e começar entender que é possivel e desejável examinar o comportamento por diferentes caminhos.

\footnotetext{
2 Diz-se de pesquisa qualitativa realizada com pequenos grupos e destinada a tentar descobrir as motivações inconscientes do consumidor (FERREIRA, 1998).
} 
A complexidade em relação aos aspectos psicológicos dos individuos, fez com que VEALEY (1992) e WHELANS, MAYERS e BERMAN (1995) chamassem atenção para as metodologias utilizadas nas pesquisas psicológicas na área esportiva, de modo que todas as investigações, com um único indivíduo ou em grupo, relatem o mais específico possível os caminhos percorridos na investigação.

- Esses conhecimentos são essenciais para educadores, professores de educação física, treinadores, psicólogos esportivos e todo o conjunto de agentes que compõem as Comissões Técnicas necessárias para o desenvolvimento das práticas esportivas do alto rendimento, bem como para a ampliação do espaço da psicologia no esporte nacional, seja na forma de pesquisa, seja no campo da prática.

\subsection{O processo de intervenção}

Além do interesse de investigar os aspectos psicológicos relacionados aos conflitos de objetivos, também nos preocupamos com o processo de intervenção. Não se justificaria a detecção das questões psicológicas que podem aprisionar e impedir o desenvolvimento de pessoas, sejam atletas ou não, somente com o intuito de coletar dados para a organização de um trabalho científico. As questões teóricas, ao nosso entender, devem ampliar as práticas. Procurarmos nesse estudo, compatibilizar as duas propostas.

\subsection{A prática da intervenção}

A entrevista psicológica caracteriza-se como um processo de intervenção uma vez que ela fundamenta o método clínico em psicologia (BLEGER, 1980). Os relatos das vivências ocorridos nesse estudo foram pontuados, firmando, deste modo, a contextura do entendimento.

Por não se tratar de uma simples coleta de dados, como nas entrevistas comuns, o processo técnico de intervenção, teve seu início a partir dos primeiros momentos, após ficarem estabelecidos e compreendidos os propósitos dessa investigação, principalmente por parte do sujeito que norteia esse estudo de caso. 


\section{QUESTÕES QUE ORIENTAM O ESTUDO}

Em função da complexidade que envolve a variável psicológica no ambiente esportivo, seja nos treinamentos, seja, principalmente, nas competições, inúmeras questões poderiam ser levantadas e abordadas sob tal enfoque. Isso tornaria um único trabalho inviável. Multiformes, os aspectos psicológicos dos atletas, nas suas práticas das altas performances, quando propostos às pesquisas, devem ser pontuais para que não se percam as referências e a fidedignidade, tal a amplidão do psiquismo humano.

A seleção dessas questões que orientam o estudo, estão relacionadas aos interesses cientificos e às experiências do pesquisador, junto à modalidade natação.

Definiram-se, portanto, como objeto principal de investigação, as referências:

1. Quais os motivos psicológicos que levam um(a) nadador(a) que, com o passar dos anos, mesmo estando melhor treinado(a), não repete nem melhora as performances apresentadas nas sessões de treinamento, quando em competições de alto nivel técnico?

2. Existe coerência e cognição entre discurso e atitude comportamental nos treinamentos e nas competições alvos, em relação aos objetivos propostos pelo praticante?

3. Resultados esportivos excepcionais obtidos podem restringir psicologicamente a evolução das performances, aprisionando os nadadores em tais conquistas?

\section{OBJETIVOS}

Verificar a viabilidade da utilização de uma conduta de diagnóstico e intervenção psicológica em uma atleta de alto nível técnico na modalidade natação que apresenta um quadro de conflitos em relação aos objetivos esportivos, identificando-os e categorizando-os, cujas resultantes podem refletir negativamente nas performances quando em eventos competitivos de alto rendimento. 


\section{REVISÃO DE LITERATURA}

Inúmeros estudos têm sido realizados com o objetivo de investigar a variável psicológica que compõe as apresentações dos atletas no ambiente de alto nivel competitivo. Considerando que o caminho de acesso à compreensão da psique pode ser conduzido por várias abordagem psicológicas e com os mais variados enfoques, procurou-se por referências que possam estar estruturando a conduta neste estudo.

\subsection{O esporte competitivo de alta performance}

A competição é um processo de comparação onde ocorre uma autoavaliação das próprias habilidades em relação aos concorrentes. A melhora das habilidades competitivas, encontra nos programas de treinamento o elemento essencial por meio do qual se pode interpretar e entender as performances humanas. É no ambiente dos treinamentos e no das competições que ocorrerá a edificação e os avanços técnicos necessários ao desenvolvimento do esporte moderno (ARNHEIM \& PRENTICE, 2002; RAPOSO,1994).

O jogo entre adversários pela busca do melhor leva os praticantes, treinadores, pesquisadores e dirigentes à procura permanente da superação dos limites humanos. Nos eventos esportivos em niveis técnicos máximos, como os Campeonatos Mundiais e os Jogos Olímpicos, observa-se uma estreita semelhança nos resultados desportivos. Os desempenhos são muito próximos, evidenciando que a capacidade de treinabilidade dos atletas de elite busca, nos detalhes, às pequenas diferenças que poderão determinar quem será o vencedor (FEIJÓ, 1998).

Dessa forma, o ambiente esportivo de excelência oferece um campo rico de ações dinâmicas, onde as teorias científicas e as práticas fundem-se para a construção, observação e aferição dos resultados. Várias ciências vêm, assim, contribuindo de maneira idônea para a superação humana no campo esportivo (GRANELL \& CERVERA, 2003).

BARBANTI (1983) refere-se, num sentido bem estrito, ao treinamento desportivo, onde a preparação de atletas volta-se para o desenvolvimento técnico, 
físico, tático, psicológico e intelectual dos mesmos, mediante exercícios físicos, cujos praticantes devem suportar cargas elevadas de treinamento para que ocorram adaptações físicas e psicológicas às demandas exigidas nas competições e/ou jogos.

Para essas aferições, protocolos dos mais diversos são utilizados pelas ciências que compõem os programas do treinamento esportivo moderno. Este conjunto de variáveis que estruturam os programas de preparação atlética, utilizam procedimentos técnico-científicos embasados em fundamentações teóricas para o controle de qualidade.

OLBRECHT (2000) observa esses conceitos efetivando-se, no momento em que os programas de treinamento são planejados, monitorados $\mathrm{e}$ os desempenhos nas competições são avaliados, não somente pelos seus tempos finais (performances competitivas), mas por todos os componentes técnicos e estratégias necessárias para tais feitos.

VERKHOSHANSKI (2001) refere-se aos resultados do confronto esportivo, como dependentes de exigências de qualidade, estabilidade e segurança de alto nivel técnico e tático, preparação moral, volitiva e estabilidade psicológica dos atletas durante as competições.

A prática esportiva em níveis de excelência, traduz a somatória de contribuição científica processada constantemente, em cujos detalhes residirão os resultados.

\subsection{A natação como modalidade competitiva de alta performance}

Como modalidade cíclica de formação de médio e longo prazo, cujos praticantes dependem do desenvolvimento das variáveis técnicas, táticas, fisiológicas e psicológicas, a natação enquadra-se no conceito de MCPHERSON, CURTIS e LOY (1989) e GRANEL e CERVERA (2003) que descreveram o esporte como uma atividade competitiva que envolve esforços físicos vigorosos e o uso de certas habilidades motoras, relativamente complexas, que requerem desenvolvimentos sistemáticos.

Em se tratando de prática esportiva de alto rendimento, a modalidade natação determina suas bases de desenvolvimento nos aspectos técnicos, situados 
nos movimentos biomecânicos dos quatros nados oficiais regulamentados pela FINA; nos aspectos táticos, onde seus praticantes utilizam estratégias que permitam distribuir sua performance ao longo das provas; nos aspectos fisiológicos, cujos treinamentos buscam por uma amplitude bioenergética para carrear o máximo de energia aos músculos envolvidos nos movimentos técnicos; e, por fim, nos aspectos psicológicos, cujo desenvolvimento permitirá que o nadador ou nadadora suporte altas cargas de estresse que envolvem os programas de treinamento, bem como as demandas emocionais situadas no ambiente competitivo (COUNSILMAN, 1977; MAGLISCHO, 1993, 2003; NAVARRO, ARELLANO, CARNEIRO \& GOSÁLVEZ, 1990; OLBRECHT, 2000; PLATONOV \& FESSENKO, 1994; WILKE \& MADSEN, 1986).

A natação competitiva realizada em piscinas com extensões de 25 metros e 50 metros por homens e mulheres, tem suas marcas e recordes aferidos por tempo cronometrado em minutos, segundos e centésimos de segundos nas distâncias que variam de 50 a 1500 metros, dependendo das formas oficiais de deslocamento aquático (livre, costas, borboleta e peito) nadados na forma individual ou de revezamento. Estes compostos por quatro atletas do mesmo gênero.

O QUADRO 1 demonstra as distâncias em metros e as formas gestuais, denominadas de nados oficiais, percorridas pelos nadadores nas provas individuais $\mathrm{e}$ de revezamentos por homens e mulheres em piscinas de 50 metros de extensão.

\section{QUADRO 1 - Distâncias e nados oficiais para ambos os sexos percorridas em piscinas de 50 metros com recordes mundiais homologados pela FINA}

\begin{tabular}{|c|c|c|c|c|c|}
\hline Distancias & Livre & Costas & Peito & Borboleta & Medley \\
\hline 50 metros & $\mathrm{X}$ & $\mathrm{X}$ & $\mathrm{x}$ & $\mathrm{x}$ & \\
100 metros & $\mathrm{X}$ & $\mathrm{X}$ & $\mathrm{x}$ & $\mathrm{x}$ & \\
200 metros & $\mathrm{X}$ & $\mathrm{X}$ & $\mathrm{x}$ & $\mathrm{x}$ & $\mathrm{x}$ \\
400 metros & $\mathrm{X}$ & & & & $\mathrm{x}$ \\
800 metros & $\mathrm{X}$ & & & & \\
1500 metros & $\mathrm{X}$ & & & & \\
$4 \times 100$ metros & $\mathrm{X}$ & & & & \\
$4 \times 200$ metros & $\mathrm{X}$ & & & & \\
$4 \times 100$ metros & & & & & \\
\hline
\end{tabular}


O desenvolvimento de um nadador de alta performance para os niveis mundiais e olímpicos requer um trabalho sistemático de médio a longo prazo, situado num período de seis a 16 anos. Os programas de treinamento evidenciam-se como peça de ciência aplicada, cuja chave para um possivel sucesso não está situada tão somente nos treinamentos de altas intensidades e nas vastas quilometragens (WILKE \& MADSEN, 1986).

SMITH, NORRIS e HOGG (2002) referem-se à natação competitiva como uma proposição de desenvolvimento de indivíduos talentosos nos seus aspectos técnicos e amparados no condicionamento fisiológico para obterem altos niveis de performances consistentes em eliminatórias, semi-finais e finais, quando assim solicitados, necessitando, para tanto, de um ambiente controlado que oportunize condições favoráveis para o desenvolvimento pleno do praticante.

Para estes mesmos autores, técnica e condicionamento físico estão respaldados por uma sólida base psicológica, tática apropriada e saúde corporal.

Para o entendimento da variável psicológica que compõe os programas de treinamentos, escopo central desse trabalho, é necessário uma incursão pelo psiquismo humano.

\subsection{Aspectos psicológicos e o ambiente de alta performance esportiva}

O ambiente esportivo, ao amoldar-se como um gerador de ansiedade elevada, pode propiciar interferências negativas no desempenho atlético. Neste sentido, pesquisadores têm enfocado a ansiedade e a sua relação com o resultado esportivo como um dos principais temas de estudos do ambiente competitivo do esporte (HACKFORT \& SPIELBERGER , 1989; HARDY, 1990; MARTENS, VEALEY \& BURTON, 1990; SMITH, 1986, 1988)

TUBINO (1979, p. 100) afirma que "cada ser humano possui uma estrutura física e uma formação psíquica própria, o que obriga o estabelecimento de diferentes tipos de condicionamento para um processo de preparação desportiva que obedeça as características físicas e psíquicas individuais dos atletas".

Essas afirmações encontram sentido, em se tratando da variável psicológica, num dos mais talentosos atletas da modalidade natação de seu tempo: o 
atleta norte-americano Mark Spitz. Detentor de sete medalhas de ouro em 1972 nos Jogos Olímpicos de Müniche, afirmou naquela ocasião que "neste nível de execução física, a diferença entre ganhar e perder é, em cerca de 99 por cento, de aspecto psicológico" (WILLIAMS, 1991).

Para LOCKE e LATHAM (1985), muitos treinadores e atletas creditam o sucesso nas competições esportivas não só às habilidades onde estão incluídas a força e o vigor, mas também aos aspectos psicológicos, cujas motivações atingem em grande magnitude a atitude mental, a confiança e a auto-eficácia dos praticantes.

Essas idéias coadunam com as de CRATTY (1984) quando acompanhamos o seu pensamento no sentido de que, embora os atletas possam apresentar semelhanças, seus talentos, emoções e sentimentos durante as atuações, surgem como uma verdadeira complexidade individual, onde variáveis externas e internas estarão intervindo diretamente de forma positiva ou negativa, nos resultados dos indivíduos, dependo de como os mesmos interpretam o meio.

Ao longo de um programa de preparação com intensidades de esforços variáveis, não só os aspectos fisiológicos passam por adaptações. As adequações psicológicas devem ser observadas com a mesma magnitude (MAGLISCHO, 1993, 2003; OLBRECHET, 2000).

Essas adaptações orgânicas motivadas pelo treinamento desportivo solicitam dos atletas altas complexidades coordenativas e tensões psíquicas por ocasião das execuções desses estímulos (MATVÉEV, 1983).

GORBUNOV (1988) cita que a competição de alta performance é um processo permanente de superação onde teoria, prática, ciência e arte estão entrelaçadas de forma muito íntima, cujos detalhes para a compreensão do fenômeno esporte requerem análises cuidadosas, sob pena de serem incompreendidos.

Segundo esse mesmo autor, nem sempre é possivel uma explicação científica rigorosa e definida para a vitória desportiva.

É justamente esta complexidade suscitada no campo esportivo que levou LESYK (1998) a enfocar as atuações da psicologia, para o entendimento das possiveis desordens psicológicas que podem acometer os atletas como qualquer outro ser humano. 
Os aspectos psicológicos que intervêm tanto positiva como negativamente nas práticas e resultados esportivos, não se esgotam no momento em que são detectados e quantificados. A compreensão desse universo invoca o grande desafio do psicólogo que pretende transitar no campo dos esportes. Ir às origens das questões, sem apriorismos que possam estar interferindo na interpretação das essências que motivam determinados comportamentos emocionais dos atletas, requer uma postura do ouvinte.

Aliar observações de campo, compreendidas entre as sessões de treinamentos e as competições, interagir com os atletas e com as comissões técnicas, tanto nas formas individuais ou de grupos, somar os embasamentos científicos, tanto da psicologia como os da metodologia do treinamento, requerem esforço e atenção contínua para que o psicólogo possa atuar de forma clara e dentro dos seus limites.

Esse apelo paradigmático motivou o delineamento deste estudo na busca pelo dizer interior do atleta de natação. Como atua e o que ocorre quando apresenta um comportamento competitivo aquém daquilo que verbaliza como sendo de suas intenções, são questões permanentes ao longo de toda essa proposta de estudo.

De outra forma, pode-se compreender o papel da psicologia como um importante suporte no auxílio do desenvolvimento das habilidades psicológicas, necessárias para o desempenho considerado como ótimo pelos atletas e pelos seus treinadores. Ao longo das suas carreiras, várias serão as demandas.

Observa-se, por exemplo, que as expectativas negativas com relação ao resultado esportivo, os chamados pensamentos negativos (MARTENS, 1987), podem elevar o nivel de ansiedade a tal ponto que resultará em fortes reações fisiológicas, intervenientes nas performances. Estas reações, ainda segundo este autor, caracterizam-se como ansiedades cognitivas e somáticas. A primeira está relacionada com a auto-avaliação negativa. A segunda é expressa mediante sensações e alterações fisiológicas, como o aumento da sudorese, taquicardias e tensões musculares, dentre outras.

Esses efeitos podem ser duradouros e extrapolar para outros setores da vida do sujeito (BRUSTTAD, 1992; CRATTY, 1984; MALINA, 1988; DE ROSE JÚNIOR, 1992; SIMÕES \& DE ROSE JÚNIOR, 1999; WEINBERG \& GOULD, 2001). 
WILLIAMS (1991) observa um interesse crescente em compreender os aspectos mentais envolvidos nas execuções esportivas, responsáveis pelas alterações psicofisiológicas. Dessa forma, segundo esse autor, é possível conduzir o treinamento de preparação para as competições de forma mais eficiente.

Para uma compreensão ampla e plena, a utilização de métodos pertinentes à psicologia poderá dar o suporte necessário ao entendimento do sujeitoatleta em todas as suas demandas psicológicas relativas ao ambiente esportivo, seja nos treinamentos preparatórios, seja, principalmente, no ambiente competitivo.

Alguns dos aspectos do comportamento humano como as emoções, não são passiveis de quantificação, em muitas ocasiões, observam BIDDLE, MARKLAND, GILBOURNE, CHATZISARANTIS e SPARKES (2001). Para PEREIRA (2001), essas manifestações excedem o escopo das representações numéricas e das premissas aritméticas, cabendo à análise qualitativa normatizar e conferir desta forma, um caráter objetivo à observação. Por essa perspectiva, muitas das respostas dos aspectos psicológicos dos atletas, complexo pela sua magnitude, não são respondidas unicamente pelo método quantitativo.

DAWAR e HORN (1992) consideram que os investigadores deveriam abandonar a crença de que existe um caminho legítimo de conhecimento na psicologia esportiva e começar entender que é possivel e desejável examinar o comportamento por diferentes caminhos.

RAPOSO (1994) refere-se à criatividade cientifica como uma constante adaptação dos conhecimentos científicos pré-existentes, reaplicados em outros domínios do contexto científico.

DALE (1996) comenta que psicólogos no campo esportivo estão sendo motivados e encorajados à consideração de paradigmas alternativos que observam nas experiências subjetivas dos atletas, um viável recurso de informações.

5.4 Objetivos Esportivos: complexidade e implicações psicológicas nos programas de treinamento e nas performances competitivas

O estabelecimento de objetivos esportivos não difere de outras atividades humanas que buscam por resultados dentro de um limites de tempo préestabelecido. 
As técnicas para o estabelecimento de objetivos advêm da área da psicologia ligada às indústrias e organizações laborais. Vasto estudo dedicado a esse campo, com alguns exemplos correlacionados nos trabalhos de CERRONE, JIWANI \& WOOD, 1991; EARLEY \& LITUCHY, 1991; LOCKE, FREDERICK, LEE \& BOBCO, 1984; LOCKE \& LATHAM, 1985; LOCKE, 1991; LOCKE, SHAW, SAARI \& LATHAM, 1991.

No campo da psicologia esportiva, esse tema tem chamado atenção, nos anos recentes, de pesquisadores e treinadores que observam no estabelecimento dos objetivos esportivos, um importante referencial para o desenvolvimento dos programas preparatórios.

A indissociabilidade entre o estabelecimento de objetivos e as melhoras das performances esportivas, transformam o tema em uma ampla possibilidade de leituras pela buscam do entendimento de como se estabelecer, de forma clara e precisa, as condutas necessárias para que o atleta racionalize suas energias da melhor forma possível quando pela busca de novas marcas, conforme (WILLIAMS, 1991).

Uma questão focal relevante ao tema OE reporta-se aos conflitos psicológicos como advindos de um estado confusional por parte dos atletas. Estes quando não possuem clareza sobre determinados comportamentos que os assolam, desenvolvem estados confusionais que podem interferir negativamente nos resultados técnicos competitivos.

Os OE delineiam os aspectos comportamentais dos praticantes, tanto para as sessões de treinamento como para as competições, podendo, de forma significativa, influenciar positiva ou negativamente nos resultados. Em se tratando de influências negativas, um dos principais papeis da psicologia é detectá-las mediante diagnóstico com a máxima precisão possível, propondo alternativas de intervenção que auxiliem os atletas reverterem essas mesmas condutas ou quadros, de forma objetiva.

BANDURA (1977, 1986, 1990) observa que para o entendimento dos métodos utilizados para a modificação dos fenômenos comportamentais, necessariamente deve-se compreender, inicialmente, as teorias onde estão os fundamentos da personalidade. A psicologia trilha por várias escolas teóricas, todas 
procurando pelo melhor entendimento do comportamento humano. Para esse autor, o comportamento do indivíduo que em sentido amplo inclui expressões cognitivas, emocionais e motoras, constitui a única classe de eventos que podem ser alterados por meio de procedimentos psicológicos, tendo na psicoterapia um método de intervenção.

Os $\mathrm{OE}$, normalmente, não são apresentados claramente num primeiro momento, o que pode resultar na construção de programas de treinamentos e expectativas competitivas irreais, onde em muitas situações, os desejos, ilusões e preferências pessoais dos agentes intervenientes significativos, formado pelo conjunto dos treinadores, pais, dirigentes e outros, podem assumir um caráter de primaz em detrimento das necessidades reais e prioritárias dos atletas. Os atletas caracterizam-se como elementos depositários das ansiedades do seu entorno, independente das suas faixas etárias e realidades técnico-desportivas. Esse fenômeno fica evidente quando observamos competições de todos os niveis, focando o comportamento de todos os integrantes que rodeiam os atletas, sejam eles mirins ou profissionais.

Os objetivos não delineiam somente a orientação dos procedimentos, mas assumem, inclusive, importante função avaliadora dos comportamentos dos executantes ao longo das suas carreiras (BANDURA \& CERVONE, 1983).

ELLITT e MESTER (2000) determinam o estabelecimento de objetivos no esporte como uma importante peça assessória no suporte aos atletas com referência à auto-confiança, satisfação, motivação, persistência, controle dos níveis ideais de ansiedade, efetivação do foco de atenção, mobilização dos esforços e estratégias para execução e toda uma rede complexa de referências para os desportistas.

Esses autores observam, entretanto, a necessidade da ampliação das pesquisas na relação entre Objetivos Esportivos e performance. Citam, inclusive, a importância de os pesquisadores "examinarem quais objetivos seriam mais apropriados para pessoas com diferentes personalidades e estilos motivacionais", ELLITT e MESTER (2000, p. 117).

GOULD (1991) e GOULD e EKLUND (1991) comentam que o estabelecimento de objetivos intervém diretamente no desempenho, pois pode criar mudanças positivas em relação à ansiedade, à confiança e à motivação. 
Partindo dessas referências, enfocamos o estabelecimento dos objetivos esportivos não como um ponto de chegada. Os objetivos esportivos se caracterizam como ponto de partida, pois devem compatibilizar discurso, cognição e ação efetiva, onde metas intermediárias criam referências para a construção do objetivo principal.

A especificação de objetivos no esporte, assume importância central no desenvolvimento e execução de programas de treinamento que implicarão, necessariamente, na mudança de comportamentos e atitudes não só por parte dos atletas mas, por vezes, de toda a CT.

Cita BANDURA (1977) que, freqüentemente, os objetivos principais dos empreendimentos de mudança social não são apresentados claramente. Essa falta de clareza de propósitos, pode resultar na permanência de programas sem direção ou oferecendo experiências de aprendizagem selecionadas de modo furtivo, principalmente quando partem das preferências pessoais dos agentes de mudança (dirigentes, pais, treinadores, etc.) e não das necessidades específicas dos receptores (atletas). Para esse autor, ao se estabelecer objetivos de modo convencional, deve-se, pelo menos, conhecer, especificar e descrever os comportamentos considerados básicos, apropriados aos resultados desejados.

Em se tratando de natação competitiva, observamos como prioritário, tanto para o entendimento como para a verificação da realidade do discurso, o quanto existe de conhecimento relacionado com o ambiente para o qual se reporta o executante na sua formulação de objetivos esportivos, bem como a compatibilidade real de intenções da Comissão Técnica (CT) e, principalmente, dos atletas.

Treinadores e psicólogos do esporte devem ter conhecimento do ambiente competitivo para onde serão canalizadas as energias, tanto fisiológicas como psíquicas do programa de treinamento. $O$ estabelecimento dos objetivos deve estar coerente não somente em relação às capacidades técnicas, mas também em relação ao comportamento e atitudes competitivas dos executantes, para que não se alimente um discurso distante da realidade. O executante deve estar o mais consciente possivel da realidade que encontrará na competição alvo ou principal, na qual estará participando no futuro. Essa postura de coerência realística deve ser objeto permanente de aferição por parte da Comissão Técnica. Um dos papéis do 
psicólogo no campo esportivo é auxiliar nesse sentido, desde que o mesmo conheça o ambiente ao qual todos estarão se conduzindo.

BANDURA (1990) observa que o comportamento é expresso em sentido amplo, por incluir um complexo de atividades observáveis e que potencialmente algumas dessas manifestações podem ser mensuráveis, cobrindo classes de respostas motoras, cognitivas, fisiológicas e psicológicas.

Essas manifestações, conforme descrições anteriores, serão possibilitadas desde que se tenha um referencial concreto para a construção dos parâmetros comparativos.

No caso da psicologia no campo esportivo, a construção dos parâmetros para análise da realidade dos objetivos esportivos propostos, será edificada mediante cruzamento da coerência e realidade do discurso do atleta, atitude competitiva nos eventos preparatórios e o seu grau de entendimento em relação ao ambiente competitivo que ele encontrará no evento para o qual são direcionadas suas intenções futuras.

Além de descrever os comportamentos que refletem as metas escolhidas, os objetivos esportivos devem, constantemente, estar sob análise qualitativa para as aferições e correções necessárias no comportamento que conduz o atleta à realidade futura, em se tratando de comportamento competitivo.

A definição comportamental dos objetivos não fornece somente orientação na seleção dos procedimentos apropriados. Desempenha, inclusive, importante função avaliadora.

Embora a especificação dos $\mathrm{OE}$ forneça orientações que permitirão as mudanças e adaptações necessárias às realidades futuras, o progresso diário é dependente da definição de metas intermediárias e das experiências de aprendizagem necessárias à sua consecução. Somatórias de experiências vivenciadas vão construindo importantes referências aos atletas, muito embora sabese que a cada novo evento, uma também nova situação será vivenciada.

Uma formulação compreensiva de objetivos deverá, portanto, conter uma seqüência de metas intermediárias que conduzam gradualmente às posturas comportamentais mais complexas (CRATTY, 1984; WEINBERG \& GOULD, 2001 WILLIAMS, 1991). 
Logo, os OE devem estar coerentes com as possibilidades reais dos atletas em relação ao evento objetivado. O posicionamento do atleta no Ranking Técnico da modalidade poderá ser utilizado como uma amostra real da situação atlética do indivíduo.

As competições esportivas apresentam características técnicas diferenciadas nos seus aspectos técnicos, grau de importância, repercussão social, politica, etc. Os OE devem observar todo o contexto.

\subsection{Conflitos e crises psicológicas relacionadas aos objetivos esportivos}

De origem grega, a palavra crise significa decisão (DANISH, PETIPAS \& HALE ,1993).

FERREIRA (1998) cita que crise pode ser definida como um estado de dúvidas ou incertezas, manifestações violentas e repentina ruptura do equilíbrio psicofisiológico, tensão e/ou conflitos.

LAPLANCHE (1991, p. 89), em seu vocabulário de psicanálise, cita o conflito "quando, no sujeito, opõem-se exigências internas contrárias...o conflito pode ser manifesto (entre um desejo e uma exigência moral, por exemplo, ou entre dois sentimentos contraditórios) ou latente, podendo este exprimir-se de forma deformada no conflito manifesto e traduzir-se particularmente pela formação de sintomas, desordens do comportamento, perturbações do caráter, etc.".

ERIKSON $(1950,1972)$ enfatiza a idéia de que os seres humanos apresentam um contínuo desenvolvimento psico-social do ego no curso de suas vidas. Os choques entre fracasso e sucesso gerarão crises, cujos conflitos atuarão como uma ponte de conexão para novos parâmetros de interação entre o indivíduo e o envolvimento social que se apresentará, em novas fases do curso de desenvolvimento emocional do indivíduo.

Esses pontos críticos no crescimento emocional humano são importantes, desde que, segundo esses autores, preparem mudanças qualitativas que tornarão possivel às pessoas vivenciarem novos caminhos em suas vidas, preparando-as 
para novos estágios, caracterizando, assim, um movimento contínuo no processo evolutivo.

Para FADIMAN e FRAGER (1986) e DABROWSKI (1996), a crise no desenvolvimento psicológico dos indivíduos pode ser importante para o psiquismo. Cita o segundo autor, ainda, que as crises são causadas pelas contradições entre o que a pessoa é e o que quer ou, mesmo, pretende ser.

$\mathrm{Na}$ psicologia do esporte, esse conceito tem sido usado, conforme STAMBULOVA (2000), para identificar situações relacionadas às quedas repentinas e/ou inconsistências nos resultados das performances, situações relacionadas às fases de transição nas carreiras, bem como situações das mais diversas que possam ameaçar a existência do desportista enquanto projetos de vida dentro da atividade. Observa, também, que a carreira esportiva dos atletas pode ser considerada com um "modelo condensado" ou um "curso miniaturizado" de um curto período de vida desses indivíduos, normalmente vivenciado de forma muito intensa. Para a autora, entretanto, o conceito de crise pode ser usado produtivamente no estudo das carreiras esportivas e nas intervenções psicológicas em esportistas.

Recorrente, esse tema encontra respaldo nos trabalhos de vários autores, como SCHLOSSBERG (1981), BAILLIE e DANISH (1992), DANISH, PETIPAS e HALE (1993), SINCLAIR e ORLICK (1993), TAYLOR e OGILVIE (1994) STAMBULOVA $(1994,1995)$.

Observando as definições anteriores, pode-se concluir que situações de conflitos internos, sintetizadas como crises, no ambiente esportivo competitivo, podem ser estudadas mediante relatos e observações das performances, em situações dinâmicas, tais como: (1) queda ou inconsistência repentina nos resultados; (2) desinteresse pela atividade e em (3) situações de conflitos em geral.

A psicologia esportiva ao analisar as situações de crises dos atletas, deve considerar a origem dos motivos que fomentam tais situações e não se situar, e tão somente, como normalmente acontece, nas discussões superficiais que influenciam os processos psicológicos adaptativos às situações existentes no ambiente competitivo. Com a aproximação dos eventos objetivados, os niveis de ansiedade são potencializados no ambiente como um todo. Nesse período, os OE assumem importante papel regulador, cuja clareza de propósitos passará a balizar o 
comportamento do atleta, mantendo-o no foco necessário para a execução ideal do seu papel, quando no campo do confronto.

Na natação, um dos momento críticos nos programas de treinamentos é denominado polimento. O tapering ${ }^{3}$, como é chamado pela escola americana, conduzida historicamente, em nível mundial, pelo lendário treinador James Counsilman (1921-2004), constitui um dos período mais críticos em todos o programas de treinamentos, ao longo da carreira esportiva dos nadadores. Nesses momentos especiais de transições para os aprontos finais competitivos dos nadadores, os OE assumem papel relevante de esteio não somente para os aspectos psicológicos, mas também para das demais variáveis que compõem o programa de preparação.

A não clareza e a inabilidade para resolver esses conflitos internos geram estresse negativo ou outras formas de desconfortos emocionais, típicos nesses processos de crises, muitos deles potencializados pelas fases distintas dos treinamentos, cujas cargas dos mesmos variam constantemente em volume e intensidade. Essas alterações nas metragens, velocidades e intensidades de nado propiciam as adaptações psicológicas e fisiológicas necessárias às performances competitivas, sendo, portanto, constantes nas sessões preparatórias. Essas situações, necessariamente, precisam ser previstas desde o início da programação.

Os objetivos esportivos assumem o papel fundamental de alicerce e equilibrio emocional às demandas do meio, tornando-se referência condutora em todo o processo desportivo desde que cognato.

\subsection{A síndrome de objetivos esportivos com projeções retroativas}

Esse estudo tem como intenção observar, detectar, compreender e descrever um comportamento específico apresentado por indivíduos praticantes de natação em níveis competitivos de alto rendimento. Esse comportamento, com tal

\footnotetext{
${ }^{3}$ Tapering é uma terminologia técnica utilizada na natação competitiva para designar a última fase dos programas de preparação, quando o atleta entra num periodo de descanso programado. Esse periodo pode durar de uma a três semanas que antecedem as competições principais, dependendo da metragem da prova a ser disputada (COUNSILMAN, 1977). No Brasil, utiliza-se o termo Polimento (Fonte: Diretoria Técnica da CBDA).
} 
especificidade, será identificado nesse trabalho como: Síndrome ${ }^{4}$ de Objetivos Esportivos com Projeções Retroativas (SOEPR).

Esse termo procura descrever um comportamento psicológico do atleta, podendo ser inconsciente, cuja característica é que, embora tenha um discurso que projeta seus objetivos esportivos para o futuro, apresenta, na prática, um comportamento competitivo conduzido para performances tecnicamente expressivas, obtidas em temporadas passadas, numa tentativa de permanência, resgate ou mesmo retorno às situações vivenciadas.

Essa atitude comportamental pode interferir negativamente na formulação e na própria clareza dos objetivos esportivos, dentro da realidade necessária à aquisição de novos patamares de desempenhos, demonstrando que o envolvimento psicológico e emocional do atleta, com suas conquistas esportivas, pode aprisioná-lo e imobilizá-lo, impedindo, desta forma, a continuidade da sua evolução técnicocompetitiva.

Como atitude psicológica que direciona o foco competitivo para ações passadas numa tentativa de resgate de situações significativas existenciais, pode conduzir o atleta para comportamentos competitivos defensivos inconscientes quando confrontado em situações no tempo presente. A interpretação do ambiente competitivo como ameaçador e a impossibilidade de retrocesso no tempo existencial podem gerar conflitos psicológicos intervenientes não só nos aspectos técnicos como também na própria permanência competitiva e na saúde mental do competidor.

Identificar os fatores que interferem na capacidade de concentração com conseqüentes resultantes de condutas, conduz naturalmente à busca dos fatores de fundo que motivam tais comportamentos.

As atitudes conflitantes dos atletas podem interferir nas suas relações com a equipe técnica, notadamente com o treinador, quando este estabelecer niveis de expectativas e projeções em relação às performances futuras. Nesse momento, para que os conflitos entre o atleta e o treinador não se acentue, colocando o programa de preparação em risco, os $\mathrm{OE}$ surgem como anteparo, desde que claros, realistas e compativeis para ambos.

\footnotetext{
${ }^{4}$ Uma sindrome é caracterizada por um estado mórbido apresentado por um conjunto de sinais e
} 
As expectativas de resultados, normalmente, são baseadas nas performances demonstradas durantes as sessões de treinamentos e competições preparatórias. Essas ocasiões, estrategicamente preparadas e previstas no início do programa, devem estar sintonizadas com os objetivos finais (longo prazos) e suas metas intermediárias (de curto e médio prazos) para que as contaminações nas comunicações entre o atleta e as demais pessoas das suas relações, sejam elas de dentro ou de fora do ambiente, não interfiram nos desempenhos.

Os objetivos esportivos motivam proposições e expectativas, muitas vezes acima ou abaixo da realidade, podendo gerar e potencializar conflitos comprometedores não só em relação às capacidades de execuções, como também em relação à carreira esportiva dos atletas (CHASE, LIRGG \& FELTZ, 1997; HORN, 1991; RAPOSO, 1994; ROSENTHAL \& JACOBSON, 1968; SOLOMON, STRIEGEL, ELIOT, HEON \& MAAS, 1996; VEALEY, 1986, 1988, 1989, 1992).

Uma conduta comum que ocorre no estabelecimento de objetivos esportivos e que podem potencializar os niveis de ansiedades pré-competitivas e competitivas, é a centralização excessiva nos resultados esportivos. Essa atitude é denominada de Objetivos Esportivos de Resultado (OER), conforme MARTENS, CHRISTINA, HARVEY e SHARLEY (1981) e BURTON (1984). Esse posicionamento pode motivar $\mathrm{o}$ atleta à atitudes defensivas, quando percebe $\mathrm{o}$ ambiente competitivo ameaçador às suas intenções e à sua própria existência enquanto esportista. Os resultados esportivos somente ocorrem após as execuções esportivas. $O$ foco excessivo nos resultados, pode afastar o atleta da auto-percepção necessária às execuções técnicas, para as quais está preparado.

Os resultados esportivos estão relacionados ao futuro, já que são obtidos somente após as execuções esportivas. Mecanismo defensivo psíquico, frente às ameaças, a ansiedade manifesta-se nas mais diferentes formas tais como as atitudes de fuga, defesa, apatia e fenômenos psicossomáticos onde as reações orgânicas, motivadas pelos aspectos psíquicos, desestabilizam fisiologicamente o indivíduo, provocando alterações que podem interferir na execução do gesto atlético. Por exemplo, podem ser apontadas como reações psicossomáticas o aumento da 
tensão muscular que levará a alterações na mecânica dos movimentos, perda parcial da sensibilidade, sudorese, palidez, taquicardia, dentre outros.

Em se tratando de natação, cujo meio aquático requer dos nadadores um alto nivel de sensibilidade e sintonia com o ambiente, essas reações podem interferir negativamente nos resultados.

Outra proposta para a formulação de objetivos esportivos, desses mesmos autores, reporta-se ao estabelecimento de metas centradas na execução da tarefa técnica da prova. São os Objetivos Esportivos de Execução (OEX), cujo foco estará centrado nos aspectos técnicos que o atleta domina e executa à exaustão nas sessões de treinamento. Os programas de treinamentos promovem adaptações das mais diversas. Os aspectos técnicos, táticos, fisiológicos e psicológicos são muitas vezes exauridos nas diferentes fases do programa. Durante a preparação, os atletas são levados para situações que simulam execuções muito próximas da realidade competitiva. Em várias ocasiões ultrapassam os limiares dessa realidade. As sessões de treinos possibilitam uma preparação psicológica para o desconforto físico, como dores das mais diversas, normalmente sentidas e assimiladas pelos atletas quando estão nos limites das suas forças durante as competições.

A capacidade de superação e a clareza de que podem executar, assim como executaram nas sessões que os prepararam para tais momentos, é a única certeza e possibilidade de controle antes do início das provas. É o que o atleta tem de real. Ou seja, a capacidade de execução. Aí estão os Objetivos Esportivos de Execução. $O$ foco, quando voltado para a tarefa, pode levar o atleta para um nivel de melhor controle da situação e, como conseqüência, fazê-lo permanecer na consciência presente da situação.

Essa atitude de não saltar no futuro pode colaborar para que os niveis de ansiedade pré-competitiva e competitiva permaneçam nos patamares ideais. A atitude ofensiva, então, pode ser potencializada.

Da mesma forma que os objetivos esportivos podem ser focados para os resultados ou para as execuções das tarefas esportivas, podem ocorrer situações onde os atletas são motivados, conscientes ou não, para o estabelecimento de objetivos esportivos com o intuito de resgatar situações vivenciadas em execuções passadas. Essa tentativa de retorno ou mesmo na resistência de despedida desses 
mesmos momentos, normalmente intensos em conteúdos emocionais satisfatórios, podem levar ao aprisionamento existencial do atleta. Essas situações normalmente interferem na evolução técnica, acentuam conflitos e inseguranças, resultando, com última instância, no abandono da prática esportiva na proposta competitiva.

Essa tentativa de retorno ou mesmo permanência emocional nas vivências esportivas, psicologicamente significante em grande intensidade, será denominada, nesse trabalho, de: Síndrome de Objetivos Esportivos com Projeções Retroativas (SOEPR).

O momento esportivo é composto de interinidade, cujo momento de glória é vivenciado intensamente, com méritos, pelo atleta. Esses momentos especiais não podem e não devem permanecer como foco permanente.

O esporte competitivo vive de projeções futuras com reformulações e adaptações constantes de metas de curto, médio e longo prazos que compõem os objetivos como um todo.

Os resultados esportivos, sejam eles positivos ou negativos, formam a peça de experiências necessárias à construção de novas referências e motivações que vão impulsionar o praticante para novos desafios, como se formasse uma espiral ascendente. A tentativa de permanência, significa girar no mesmo plano, sem o movimento de ascensão.

A tentativa de permanência, retorno ou imobilidade nas situações vivenciadas, configuram-se como um impedimento para o desenvolvimento emocional do ser humano.

Como o ser humano é tendencioso psicologicamente para a extensão das situações prazerosas, no esporte essa situação é presente. O ambiente esportivo é vivenciado intensamente pelos atletas. Esses, em um determinado momento das suas vidas, o tem como a única referência de existência, enquanto individuos no mundo.

Ao atingirem niveis de excelência no esporte de alto rendimento, os atletas devem ser conduzidos a um novo redimensionamento psicológico frente aos objetivos esportivos. É o processo de readequação em todos os sentidos, das variáveis que compõem os programas de treinamentos. 
Situações ameaçadoras ao "status quo" podem gerar manifestações de ordem psicológica das mais diversas, tais como: irritação e angústia com a perda de destaque no grupo, sensação ou perda real das atenções exclusivas e preferenciais das CTs, divisão de espaço na mídia, desmotivação e baixa alta estima, dentre outras. Muitas delas, inconscientes, necessitam de intervenção especializada para serem re-significadas, permitindo, desse modo, a continuidade da trajetória das escolhas do sujeito dentro das realidades presente e futura.

O ambiente competitivo permite leituras psicológicas diversas que serão manifestadas no formato de ansiedade. Quando o ambiente é interpretado como ameaçador a sua dimensão assume papeis ultra-dimencionados. Essa leitura pode ocorrer frente aos adversários, aos ambiente e ao público.

A FIGURA 1 procura esquematizar as duas tendências de atitudes competitivas dos atletas quando projetam suas metas com apelos para ações passadas e para ações futuras.

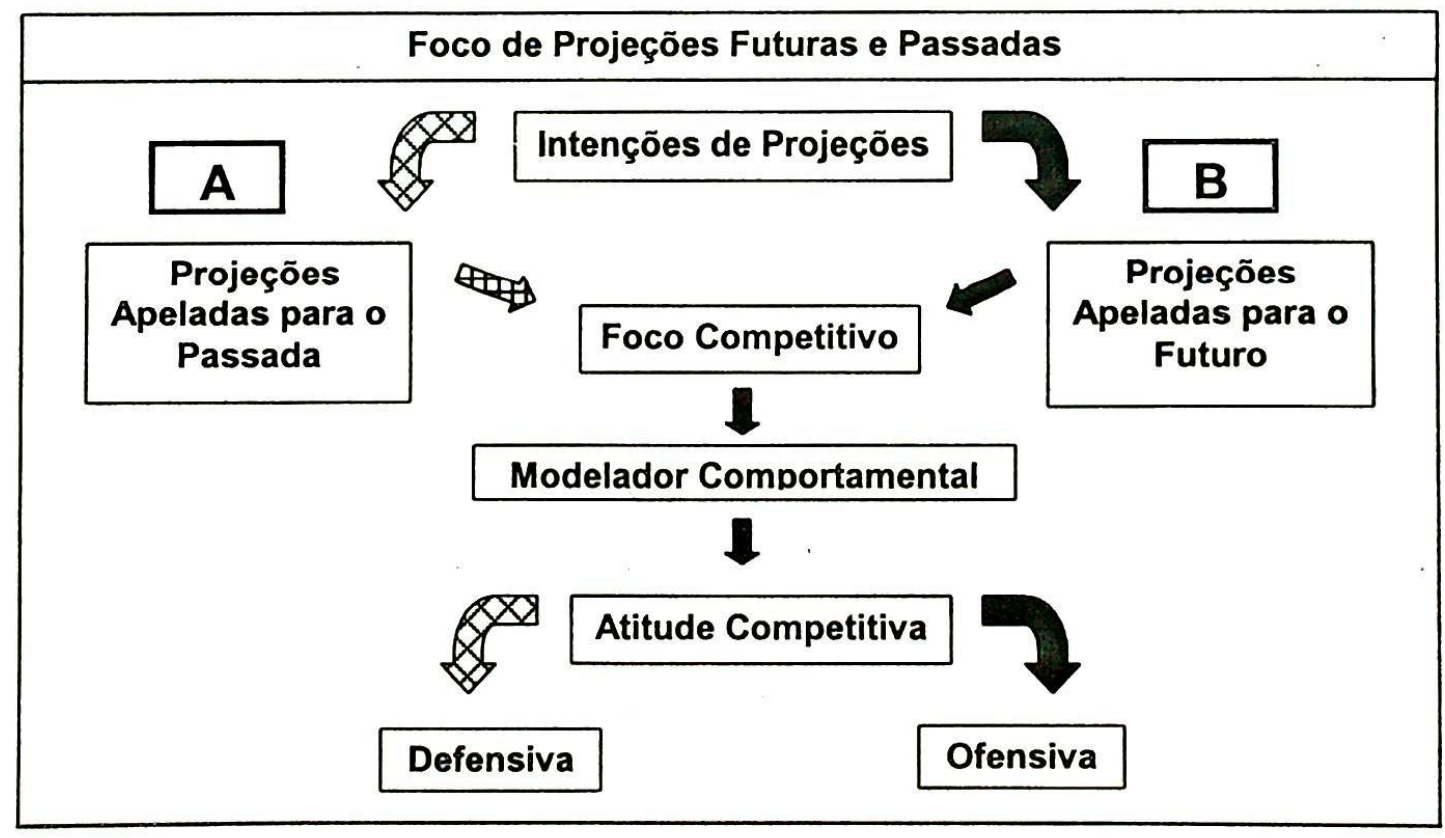

FIGURA 1 - Demonstrativo de comportamento resultante do foco esportivo centrado em projecões futuras e passadas

(A)Tendência de projeção de Objetivos Esportivos voltados para performances Passadas, motivando atitudes competitivas defensivas.

(B)Tendência de projeção de Objetivos Esportivos voltados para performances Futuras, motivando atitudes competitivas ofensivas. 
As intenções de objetivos voltadas às performances obtidas no passado, representadas pelo seguimento $(A)$, demonstram que a busca ou tentativa de retorno às ações vivenciadas, ou seja, resultados ou momentos esportivos psicologicamente significativos, podem conduzir o foco competitivo, que é um modelador comportamental, para atitudes competitivas defensivas, potencializando, dessa maneira, atitudes apáticas ou automatizadas sem a devida presença de consciência, onde o receio do fracasso assume altas dimensões com também altos niveis de ansiedade. A tentativa de retorno mostra $\circ$ quanto 0 atleta está preso emocionalmente com as suas conquistas.

Esse aspecto emocional pode impedir o desenvolvimento e até mesmo a continuidade de prática do atleta, principalmente quando o mesmo assume uma relação com a competição sob forte sentimento de ameaça, não entendo, na maioria das vezes, as razões ou a origem de tais sentimentos e sensações.

Já nas intenções de objetivos voltados às projeções futuras dentro dos padrões técnicos de realidade, representados pelo seguimento (B), o foco competitivo quando se volta para a consciência das execuções técnicas, exaustivamente treinadas durante as fases de preparação, respaldam a confiança do executante. O foco na execução pode modelar o comportamento do atleta, conduzindo-o para atitudes competitivas ofensivas, motivando-o, inclusive, à combatividade. Os níveis de ansiedade, desta feita, podem ser canalizados a essas mesmas ações positivamente.

A análise desses objetivos pode ser feita através de uma abordagem fenomenológica que será o objeto de estudo desse trabalho.

\subsection{A pesquisa fenomenológica na psicologia esportiva}

DAWAR e HORN (1992) e DALE (1996) propõem uma ampliação dos caminhos interpretativos dentro da psicologia voltada para o esporte, objetivando a compreensão do atleta.

Partindo dessa referência, esse estudo buscará o entendimento de alguns fenômenos comportamentais de nadadores de alto rendimento, mediante uma leitura de psicologia fenomenológica. 
Os fundamentos que delimitaram os estudos do filósofo alemão Edmundo Husserl (1859-1938), como a "busca das essências" ou o "retorno às coisas mesmas", movem, inicialmente, a proposta investigativa dos conflitos psicológicos em relação aos objetivos esportivos em atletas de elite, na modalidade natação.

Essa proposta tem em HOLANDA (2001) uma referência considerável, quando o autor observa a importância e a necessidade do conhecimento mínimo sobre "filosofia fenomenológica" para que se possa, então, desenvolver a "psicologia fenomenológica". Completa, ainda, esse autor que, caso esses cuidados não sejam observados, corre-se o risco de se fazer uma "colagem de perspectivas distintas".

O objetivo do estudo em curso, todavia, não é adentrar pela complexidade da filosofia fenomenológica, pois estaria extrapolando o escopo dessa proposta de pesquisa.

A busca pela amplitude desses conhecimentos dos aspectos comportamentais dos atletas, motivou uma aproximação da fenomenologia desenvolvida pelo filósofo alemão Edmundo Husserl que, unida com a filosofia da existência proposta pelo dinamarquês Soren Kierkegaard, encontrou no também filósofo alemão Martin Heidegger a união dessas duas filosofias para a descrição das experiências dos indivíduos (VEALEY, KING \& HALLING, 1989).

É nesse movimento de voltar às coisas mesmas, de ir ao encontro das essências duas expressões humanas, que podemos, via consciência, obter o caminho da intencionalidade (FORGHIERI, 1997; FRAGATA, 1962).

A fenomenologia busca pela compreensão de como o indivíduo existe no mundo, a cada instante, a cada momento, dentro da sua singularidade (CRITELLI, 1996).

AMATUZZI (1996) observa que a metodologia fenomenológica pode fundamentar as pesquisas empíricas da psicologia fenomenológica no campo da psicologia. Completa, citando como exemplo os trabalhos de GIORGI (1985), GOMES $(1985,1989,1998)$ e FORGHIERI (1997).

FORGHIERI (1997, p. 34) cita que "para compreender a expressão viva de uma pessoa, é necessário tentar captar, intuitivamente, a sua vida, conforme é por ela própria vivida; ou, em outras palavras, é preciso procurar penetrar no existir da 
pessoa, para descobrir, além das palavras e dos gestos, o sentido que se encontra contido na sua comunicação".

Essa aproximação qualitativa de escuta (GIORGI, 1994) requer uma postura do pesquisador, no sentido de que ao distanciar-se dos seus próprios préconceitos, tenha um encontro autentico com o seu interlocutor e assim acompanhá-lo no transcorrer das suas experiências vivenciadas.

É justamente na compreensão das vivências que o saber fenomenológico procura o caminho da intencionalidade das ações humanas. Do ser-no-mundo do sujeito entrevistado (FORGHIERI, 1997).

A fenomenologia busca na experiência a consciência relacional entre vivência e sujeito. Para apreender e compreender o sentido das vivências e possibilitá-las à consciência, é preciso uma escuta livre, desprendida. Um comversar-com próximo e autêntico entre sujeito-atleta e pesquisador.

Esse afastamento das formas pré-conceituais, de julgamentos, valores e posturas pré-estabelecidas é o caminho pautado pela fenomenologia (GOMES, 1998). Segundo o autor, "será neste contexto que se introduzirá a entrevista como um convite à comunicação" (p.31).

GOMES (1998, p. 22) cita, ainda, nos seus estudos fenomenológicos de pesquisa em psicologia, que "as contribuições de estudos teóricos e experimentais são fundamentais para este avanço técnico da psicologia, desde que acompanhados de cuidadosa análise do que se toma por pressuposição de uma substância ou realidade e do que é factível de descrição sobre uma substância ou realidade".

Estes estudos e a prática no dia-a-dia nas piscinas motivam o olhar na perspectiva fenomenológica como um importante e viável caminho, dentre tantos outros, de inegável significância na psicologia, para o entendimento das questões psíquicas que permeiam o ser atleta. Este contido num ser de inegável incomensurabilidade: ser humano.

Embora o fenômeno esporte envolva o atleta numa aura mítica, os desportistas existem na condição humana real. Essa humanidade deve ser observada criteriosamente no campo esportivo, pois é ela a condição de base do atleta. 
MAY (1976, p. 13) observa que "nenhuma pessoa submeter-se-á ao doloroso processo de desvendar os níveis mais profundos de seus conflitos, suas angústias, seus anseios - não a uma outra pessoa, certamente, e raramente a si mesma - a não ser que por esse processo ela tenha alguma esperança de superar seus bloqueios e aliviar o seu sofrimento".

Nesse sentido, para a aproximação investigativa dos conflitos psicológicos relacionados aos Objetivos Esportivos no ambiente de alta competição, deve-se optar por um caminho claro e demarcado para que o pesquisador não perca o destino, observe suas próprias ansiedades e, principalmente, não salte no futuro do atleta.

Para MAY (1976, p. 16), "a ênfase existencialista em psicologia não nega a validade do condicionamento, a formulação de impulso, o estudo de mecanismos individualizados, e assim por diante".

O Existencialismo surge não como um sistema ou método, mas como uma atitude que envolve a centralização na pessoa existente e enfatiza o ser humano como emergente, em evolução, ainda segundo esse autor.

\subsubsection{A redução fenomenológica e a análise interpretativa das entrevistas}

Para FORGHIERI (1997), a redução fenomenológica acontece como um processo dinâmico, que leva o pesquisador a se envolver com a vivência investigada. Segundo a autora, esse procedimento, denominado de "envolvimento existencial", permitirá a apreensão das vivências do indivíduo em toda a sua autenticidade. Ao afastar-se para compreender e refletir sobre o vivido, estará no movimento denominado de "distanciamento reflexivo".

CARVALHO (1991) cita que a redução fenomenológica é a forma de acesso que o observador tem para "penetrar" nos "objetos" vividos. Esse movimento se concretiza mediante a empatia ${ }^{5}$. Essa postura é indispensável para que se pratique a entrevista numa abordagem fenomenológica, segundo esse mesmo autor.

5 Empatia é a tendência para sentir o que sentiria caso estivesse na situação e circunstância experimentadas por outra pessoa (FERREIRA, 1998). 
BORDINI (1990) cita que a redução fenomenológica não destrói a verdade da atitude natural. Apenas busca pelo esclarecimento do sentido.

Para HOLANDA (2001), a redução é a via de acesso ao fenômeno tal como ele é constituído na totalidade.

No envolvimento existencial, dada a aproximação de quem escuta para apreensão das vivências, via conteúdo discursivo, e o distanciamento reflexivo para a compreensão isenta de apriorismos destas mesmas vivências, reside a redução fenomenológica.

\subsubsection{O método fenomenológico na investigação das vivências no campo esportivo}

FORGHIERI (1997) transpõe o método fenomenológico da filosofia para a psicologia, objetivando apreender o sentido ou o significado da vivência de pessoas em determinadas situações.

O evento competitivo é único em se tratando de esporte. Ele acontece dentro de um determinado momento que não se repetirá. A peça histórica do esportista é composta pelos objetivos esportivos, intermediados pela metas de curto e médio prazo. A somatória das experiências que se sucedem, comporão o conjunto das vivências, tornando-se, então, o objeto da investigação.

OKUMA (1998, p. 25), ao afirmar que "sendo cada uma das experiências humanas impregnadas de subjetividade" e que "quanto mais compreendemos tais subjetividades, mais compreendemos a própria experiência", mostra o quanto se torna possivel acompanhar as questões vivenciadas pelos esportistas. Corrobora nesse contexto BICUDO (1999), ao afirmar que a fenomenologia pode ser entendida como o estudo que reúne os diferentes modos de aparecer do fenômeno ou o discurso que expõe a inteligibilidade em que o sentido do fenômeno é articulado.

Aí reside, conforme EPIPHANIO (2001), a fenomenologia como forma de entendimento dos sentidos das vivências como eles aparecem.

A fenomenologia existencial, como articulação de um discurso impregnado de sentidos e sentimentos, mostra-se viável como postura metodológica de pesquisa no campo esportivo. Uma vez que a proposta fenomenológica possibilita uma 
aproximação das experiências vivenciadas pelos esportistas e cujo movimento por parte do pesquisador, denominado de envolvimento existencial e distanciamento reflexivo por FORGHIERI (1997), terá nas palavras do seu interlocutor o que AMATUZZI (1996) entende por fenomenologia de tendência dialética. A coleta de dados, com participação ativa do pesquisador, permitirá à apreensão e compreensão dos fatos que compõem os fenômenos, indicando, então, "as decisões que devemos tomar". Essas informações podem colaborar com as Comissões Técnicas e com os praticantes no que se refere às formulações dos objetivos esportivos, dentro do princípio da realidade.

\subsubsection{Pesquisa em psicologia fenomenológica no campo esportivo}

Como procedimento metodológico no campo da psicologia fenomenológica no ambiente esportivo, esse estudo propõe os procedimentos sugeridos por GIORGI (1985) e descritos por HOLANDA (2001), compreendidos em:

1 - Apreensão do Sentido do Todo

2 - Discriminação das Unidades de Significado

3 - Transformação em linguagem psicológica

4 - Síntese das unidades de significado

(1) A Apreensão do Sentido do Todo

Nesse primeiro momento, ocorrerá a leitura de toda a descrição das vivências significativas, com o objetivo de se obter o sentido global do que está sendo descrito.

(2) Discriminação das Unidades de Significado

É descrita como um momento onde, segundo o texto, ocorre uma "atitude psicológica" em que os conteúdos serão divididos em unidades para serem trabalhados, objetivando a captação dos momentos de mudanças psicológicas significativas de cada situação descrita pelo indivíduo. FRANÇA (1989) descreve que as unidades de significado não existem per se, mas em relação à perspectiva adotada por quem as analisa. 
(3) Transformação em Linguagem Psicológica

Nesse momento, os conteúdos das falas do sujeito são analisados e interpretados, verificando-se exatamente o que o narrador expressa em relatos.

(4) Sintese das unidades de significado

Nessa fase, ocorre a sistematização consistente da experiência do sujeito. O desvelar poderá trazer à luz da compreensão, o sentido dos conteúdos narrados.

LAZARUS (2000) observa que, para serem determinadas as emoções mais importantes que ocorrem nas competições esportivas, é necessária uma descrição cuidadosa, por parte do atleta, das suas experiências em diferentes condições de treinamentos e de competições. Para este autor, o contraste entre emoções negativas e positivas deve ser observado e também em que contextos elas ocorrem. As emoções descritas pelos indivíduos podem estar contidas no campo subjetivo. As conseqüencias sociais ou se algum antecedente especifico suscitou o desencadeamento de reações emocionais intervenientes nos resultados esportivos, devem ser observadas criteriosamente pelo investigador, pois muito dos conteúdos emocionais estão contidos no discurso do sujeito. As falas, portanto, estão cheias de significados emocionais que mostram não somente o indivíduo atleta, mas ele por inteiro.

\subsection{A entrevista psicológica}

A entrevista psicológica foi o instrumento utilizado para fundamentar o método clínico, sendo, portanto, uma técnica de investigação científica em psicologia (BLEGER, 1980). Para este autor, a entrevista psicológica deve ser entendida como um importante instrumento na investigação, diagnóstico e na própria terapia. É uma ferramenta preciosa da qual se vale o psicólogo para a execução do seu ofício.

A entrevista não é uma simples coleta de dados, como observam BIDDLE et al. (2001), onde em muitos artigos de pesquisas quantitativas os pesquisadores normalmente limitam o método de entrevista neste sentido. 
Para DREHER (1994), alguns problemas metodológicos podem ser evitados se não houver excessiva e, por vezes, exclusiva confiança nos dados verbais. Ainda para este autor, é possivel que a entrevista não abranja amplamente a investigação, caso os dados não sejam tratados de forma adequada. Cabe então observar se a metodologia está bem fundamentada.

GILBERT, TRUDEL e HAUGHIAN (1999) citam que alguns processos cognitivos observados pela psicologia esportiva, tais como tomadas de decisões $\mathrm{e}$ aprendizados mediante experiências, não podem ser explicados em uma simples entrevista, pois os atletas não têm capacidade para interpretar suas ações intuitivas.

CULVER, GILBERT e TRUDEL (2003) relataram que quando várias formas de observar as atividades humanas são combinadas com as entrevistas, possibilitam uma melhor compreensão dos processos que envolvem o contexto esportivo.

A entrevista psicológica aberta não se fundamenta num simples perguntar e ou recolher dados da história do entrevistado. Na entrevista psicológica, será estabelecida uma relação humana entre duas ou mais pessoas, onde um ouvir especial permite um aproximar do sujeito que busca pela compreensão plena do seu existir e dos possíveis conflitos que o afligem, impedindo assim o seu desenvolvimento pleno (ANGERAMI-CAMON, 2002; BLEGER,1980).

\subsubsection{A entrevista psicológica como campo de atuação}

Na entrevista psicológica, o campo de atuação tem característica definida para a investigação da personalidade ou de determinada circunstância comportamental. $\mathrm{O}$ enquadramento é rígido. Procura-se transformar um conjunto de variáveis em constantes. BLEGER (1980, p. 15) cita que "os indivíduos possuem personalidade sistematizada em uma série de pautas ou em um conjunto ou repertórios de possibilidades, e são estas que esperamos que atuem ou se exteriorizem durante a entrevista".

GARRET (1967, p. 24-25), ao observar que "as causas inconscientes são muito mais comuns do que originalmente se julga, quando se procura compreender 
as pessoas", mostra que o sujeito da entrevista pode não ter clareza das questões que $o$ aflige.

Cabe ao psicólogo ir às causas que podem estar nas profundezas da personalidade. Essas questões estão além da compreensão do sujeito que as demonstra mediante ansiedades, temores, tristeza e sofrimento.

Observa-se que a entrevista psicológica é uma técnica, onde a escuta é executada mediante fundamentações teóricas da psicologia que permitirão um compreender dos sentidos que estão compostos na fala do sujeito. Neste procedimento, o entrevistado conduz a entrevista, porém o psicólogo terá sempre o controle do processo.

\subsubsection{A experiência no campo esportivo e a entrevista psicológica com abordagem fenomenológica}

Aqueles que pretendem atuar no campo esportivo, incluso os aspectos psicológicos, devem conhecer esse ambiente e suas demandas. As modalidades esportivas apresentam características próprias de comunicação, métodos de desenvolvimento, controle de treinamento e regras competitivas. $\dot{E}$ importante para o psicólogo conhecer a modalidade pela qual pretende transitar, aproximando-se, inclusive, dos colegas especialistas das outras áreas que compreendem a complexidade inserida nos resultados esportivos (BUCETA,1991,1995,1998). E justamente esse conhecimento, experiência e trânsito, progressivo, junto à modalidade esportiva eleita que permitirá uma intimidade por parte do pesquisador com relação às demandas psicológicas, sejam elas no treinamento, em toda a sua periodização ou, principalmente, nas competições, ainda segundo este autor.

Detalhe importante que permeia os grandes resultados esportivos no ambiente do alto rendimento: todas as conquistas no esporte moderno, estão alicerçadas na aplicação da ciência e para tanto, somente o trabalho em equipe intermodal permitirá tais construções, notoriamente, a longo prazo por se tratar de desenvolvimento humano.

Esse conjunto de itens importantes vai permitir o delineamento, portanto, do roteiro utilizado durante a entrevista (EPIPHANIO, 2001; GOMES, 1998). 
No "conjunto de itens", estão compostos todos os aspectos que, consciente ou inconscientes, interferem na dinâmica psíquica do sujeito com o mundo no qual está inserido. HAMILTON (1982) denomina de "fato humano" as questões que compõem essa interação do sujeito e a sua forma de estar no mundo. Aspectos mentais, físicos, sociais, econômicos, sexuais e afetivos constituintes do ser humano atuam sobre o indivíduo e na sua relação com o meio.

A investigação explicativa que busca pelas causas que comporão o diagnóstico esbarra na compreensão do sujeito. Muitas das questões que permeiam os conflitos existenciais não estão ao seu alcance. Para a busca da compreensão conjuntamente com o sujeito da vivência, o pensamento fenomenológico enquadrase como uma opção adequada para esse tipo de investigação.

A compreensão por parte de quem vivencia, ou seja, o sujeito dos fatos vividos, transcende o saber que se dá no diagnóstico. Ir às questões originárias com o sujeito, no seu tempo de compreensão, com livre escuta, tendo-se o cuidado de não saltar no futuro, permitirá ao investigador e ao sujeito construírem o saber do fenômeno, cujo movimento se denomina "redução fenomenológica".

CARVALHO (1991) refere-se ao saber do fenômeno essencialmente como uma "construção de sentido".

Essa construção de sentido, citado pela pesquisadora, conduz à compreensão e aproximação da psicologia existencial fenomenológica no campo esportivo investigativo do alto rendimento, cuja proposta precípua é o desempenho das performances em harmonia com os aspectos de saúde do atleta. ${ }^{6}$

6

$$
\text { METODOLOGIA }
$$

\section{1 \\ Caracterização da pesquisa}

A metodologia utilizada nessa pesquisa foi motivada por WHELAN, MEYERS e DONOVAN (1995) e VEALEY (1992), quando sugeriram que as pesquisas no campo da psicologia esportiva, em grupo ou em um único sujeito,

6 A exposição sistemática do método fenomenológico foge aos objetivos deste trabalho. Seus aspectos estão ligados como possibilidade de embasamentos, necessários à busca da compreensão 
deveriam observar uma descrição mais especifica das intervenções utilizadas para que se possa dar continuidade ao avanço na área.

Partindo desta premissa, buscou-se por uma aproximação da psicologia existencial fenomenológica (MAY, 1976) para com a área esportiva, como um meio de entendimento do comportamento e reações psicológicas nos períodos preparatórios e competitivos da modalidade natação em atuações de alto rendimento.

Portanto esta pesquisa terá caráter estritamente qualitativo, através de uma abordagem fenomenológica em um estudo de caso.

\subsection{Sujeito da pesquisa : um estudo de caso}

Foi observada uma atleta pertencente a uma equipe com representatividade nacional, histórico esportivo, competitividade comprovadas com as seguintes características:

a. Histórico esportivo de altas performances em eventos de âmbito estadual, nacional e internacional

b. Oscilação e inconstância nos tempos com piora acentuada após resultado técnico expressivo em algum momento da carreira esportiva, sem motivos aparentes

c. Bom desempenho nos treinamentos

d. Atitude competitiva apática não compatível às ações comportamentais apresentadas nos treinamentos

e. Discurso confuso em relação aos objetivos esportivos

f. Pertencente à categoria oficial de Sênior

g. Dez anos de prática competitiva

h. Dezoito anos no início da pesquisa 


\subsection{Instrumentos}

Os instrumentos utilizados para a pesquisa foram:

a. Histórico esportivo

b. Observação sistemática nos treinamentos e nas competições

c. Entrevistas de diagnóstico e intervenções psicológicas esportiva

\subsection{Procedimentos}

Conjuntamente com os contatos iniciais com a nadadora para o início desse estudo, foi realizada uma entrevista com o treinador e coordenador administrativo das equipes competitivas da instituição à qual pertence a atleta, para os esclarecimentos necessários referentes aos objetivos da pesquisa, condições para as devolutivas e trânsito do pesquisador junto à Comissão Técnica, às sessões de treinamentos e às competições objetivas pelo programa de preparação do time.

Foram realizadas duas entrevistas iniciais com a nadadora para os esclarecimentos dos objetivos da pesquisa, do Termo de Consentimento (ANEXO 1), e condutas (locais e horários das entrevistas) necessárias para a realização do trabalho e continuidade do mesmo em caso de interesse por parte da atleta, após o término desse estudo.

Esse procedimento inicial objetivou dirimir todas as dúvidas junto aos envolvidos (Comissão Técnica e Atletas) que pudessem pairar sobre as intenções do estudo e, principalmente, pela ética que deve pautar todo e qualquer trabalho científico.

Com duração prevista e fixada inicialmente em cinqüenta minutos, as entrevistas foram gravadas para análise posterior dos conteúdos vividos de forma mais fidedigna possivel. $\mathrm{O}$ tempo de duração das entrevistas não seguiram um padrão fixo como os utilizados nos atendimentos da psicologia clínica. O local para as entrevistas foi sendo escolhido dentro do ambiente de preferência da atleta. Foram utilizadas: sala tipo consultório, o ambiente da piscina, sala de musculação e 
ginástica, ginásio poliesportivo, dentre outros. Um aspecto importante, sempre observado, foi a privacidade e adequação sonora desses locais. A nadadora, na maioria dos encontros, opinou sobre os locais das entrevistas.

Após anuência dos envolvidos, os procedimentos seguintes foram:

\subsubsection{Obtenção do histórico esportivo}

O histórico esportivo da nadadora foi obtido mediante pesquisa nos Boletins Técnicos da Confederação Brasileira de Desportos Aquáticos - CBDA, onde constam os resultados oficiais dos principais eventos do calendário esportivo anual do país. Esses Boletins Técnicos contêm os tempos e colocações obtidas em campeonatos e torneios dirigidos pela entidade nacional ou pela sua representante estadual (Federação Aquática Paulista - FAP). Esses documentos permitiram o ordenamento dos resultados da principal prova da nadadora, 100 metros nado Peito, disputados em piscinas de 50 metros, nas temporadas esportivas dos anos de 1999, 2000, 2001, 2002 e 2003.

\subsubsection{Observação sistemática nos treinamentos e nas competições}

A nadadora foi acompanhada durante as sessões de treinamentos e nas principais competições de níveis estaduais e nacionais, realizadas em piscinas de 50 metros. As observações aconteceram ao longo das temporadas esportivas dos anos de 2003 e 2004, com início nos meses de janeiro e término nos meses de dezembro (Macro-Ciclos). Cada temporada foi dividida em dois blocos (Meso-Ciclos) contendo seis meses. Os treinos semanais (Micro-Ciclos) foram compostos de sete dias, seguindo o que preconiza NAVARRO et al. (1990) e MAGLISCO $(1993,2003)$. Quando não ocorriam competições nos finais de semana, os domingos foram reservados para o descanso da atleta. Fato previsto como um fator importante dentro do programa de preparação no só do ponto de vista fisiológico mas também psicológico. Durante as sessões de treinamento, procurou-se acompanhar o desempenho nas principais séries de execuções que visavam a melhora qualitativa 
das produções energéticas, fisiologicamente significativas para a aquisição das performances competitivas.

\subsubsection{Entrevistas de diagnóstico e intervenções psicológicas esportivas}

As entrevistas foram programadas após reuniões com a Comissão Técnica e com a nadadora separadamente, para que fossem dirimidas dúvidas com relação ao estudo e formas de atuação do pesquisador tanto nas sessões de treinamento como nas principais competições do calendário esportivo.

As entrevistas tiveram como objetivo a construção do sentido das questões vivenciadas ao longo da história esportiva e da vida da atleta como um todo, seguindo os procedimentos:

c.1 As entrevistas foram gravadas com o propósito de possibilitar a análise dos conteúdos na sua integralidade.

c.2 As entrevistas ocorreram normalmente uma vez por semana a princípio. Esses encontros, em algumas ocasiões, estenderam-se por duas ou três vezes, sempre que solicitado pela atleta.

c.3 0 contrato $^{7}$ foi acordado na primeira entrevista, quando se tratou dos objetivos da pesquisa nos seus detalhes e onde foi assinado o Termo de Consentimento após detalhado e entendido (ANEXO 1). Não foi necessária a autorização dos responsáveis pela nadadora, sendo a mesma maior de idade no início da formalização desse estudo.

c.4 O número de entrevistas iniciais foi estabelecido após entrevista com a Comissão Técnica, objetivando obter dados informativos a respeito das características técnico-competitivo-comportamentias da atleta, bem como informações sobre a pesquisa e formas de devolutivas.

c.5 A anuência da CT, principalmente por parte do treinador responsável pela equipe, tornou-se fundamental para o início dos trabalho, uma vez que a incorporação do pesquisador no grupo era fundamental para as

\footnotetext{
${ }^{7} \mathrm{O}$ termo Contrato é utilizado em psicologia para designar um acordo de intenções entre o psicólogo e o cliente. Não se trata, no caso dessa pesquisa de acordo de preços por serviços prestados, mas dos limites, propósitos e circunstâncias em que ocorrerão as entrevistas.
} 
observação durante os treinamentos e, principalmente, nas competições. Esse procedimento permitiu uma objetividade nas observações da atleta que se enquadrou na proposta da pesquisa, possibilitando, inclusive, aproximações e vínculos, uma vez que os grupos esportivos são fechados e sistemáticos.

c.6 A análise comportamental tanto da atleta como do grupo como um todo "in loco" ocorreu nas (a) reuniões coletivas e individuais que a CT efetuava, principalmente no inicio das temporadas esportivas onde são estabelecidas todas as estratégias adotadas nos treinamentos; (b) nas observações do sujeito pré-selecionado durante as sessões de treinamento; (c) nas competições que compuseram o periodo inicial das temporadas esportivas, bem como em todos os eventos em que a equipe estive participando.

c.7 as entrevistas foram divididas em:

(a) entrevistas iniciais, onde se objetivou a história da atleta como um todo - anamnésia

(b) entrevistas psicológicas de diagnósticos e intervenção

Nas competições objetivadas pela nadadora, como os campeonatos estaduais e nacionais, a atleta foi observada nas suas atitudes comportamentais pré e pós-competitiva. Nesses eventos procurou-se preservar a privacidade da nadadora, aguardando, em todas as ocasiões pela sua iniciativa para uma conversa mais próxima, referente às suas atuações, fossem elas em momentos que antecediam as atuações ou após as mesmas.

\subsection{Análise dos dados}

Para a análise das entrevistas, os procedimentos seguiram as proposições sugeridas por GIORGI (1985), descritas por HOLANDA (2001, p. 43) e embasadas na fenomenologia por CARVALHO (1991). Esses procedimentos estão compreendidos em: 
1 - Apreensão do Sentido do Todo

2 - Discriminação das Unidades de Significado

3 - Transformação em linguagem psicológica

4 - Sintese das unidades de significado

As apreensões dos sentidos, contidos nas descrições vivenciadas, não se restringiram somente aos fatos relacionados às questões pontuais. Todas as experiências passaram a constituir a história do sujeito, caracterizas como um todo na relação mundo-sujeito. Os relatos, embora conduzidos livremente pela atleta, estiveram sob controle do pesquisador, de modo que, na busca dos sentidos que caracterizavam a intencionalidade, permitiam, mediante tal postura, a construção da compreensão e o início de um conhecimento de como a atleta interagia emocionalmente com o mundo, onde também está contido o ambiente esportivo.

Partiu-se do princípio de que o "ser atleta" ocupa um momento existencial com relevante significado emocional na vida desse indivíduo. Questões relacionadas ao ambiente esporte ocuparam a maior parte dos encontros, mas não necessariamente ficou-se atado aos aspectos do ambiente e sentidos da prática esportiva. A fala não esteve centrada nas somatórias dos pensamentos que compunham as idéias de forma explicativa. Era de se esperar que todo o ser-atleta surgisse no contexto das entrevistas. O ser-atleta está inserido no ser-total-humano. Embora o esporte assuma importante dimensão existencial.

A discriminação dos sentidos, permitiu o agrupamento dos fatos que compunham significativamente a história vivencial da atleta. A medida em que o processo foi se desenvolvendo, o sujeito, como um todo foi se desvelando.

Para a pesquisa em curso, os fatos esportivos mais marcantes, sejam eles positivos ou negativos, foram conjugados de forma a permitir uma leitura interpretativa mediante linguagem psicológica.

A linguagem psicológica não é expressa somente em palavras. Ela é gestual, tonal, silenciosa e resistente. Simbólica, expressa atemporalidade onde passado e futuro surgem no presente. Através do discurso, a atleta envolveu-se emocionalmente com os aspectos mais íntimos e, por vezes, desconhecidos da sua forma de estar no mundo. CARVALHO (1991, p. 39) observa que "nesses momentos percebe-se um sentido que transcende o emprego das palavras, dos vocábulos e 
expressões culturais e idiomáticas próprias da cultura e da língua em que se exprime". Esse momento é singular, próprio e intenso.

A sintese das unidades de significados objetivou a conjugação dos fenômenos à consciência e ao entendimento.

O entendimento foi ocorrendo à medida que a atleta ia se dando conta, mediante as explicitações dos seus gestos, expressões e falas referentes aos seus fatos vivenciados.

A sintese é o momento da reflexão da atleta com referência aos seus engajamentos. A forma como vem se relacionando com a sua história. Com o fenômeno da compreensão, a atleta pode refazer o sentido, alterar o curso da sua história frente às questões que pontuavam a sua vida naquele momento.

\section{RESULTADOS: APRESENTAÇÃO E DISCUSSÃO}

\subsection{Histórico esportivo}

Os resultados técnicos contidos na TABELA 1,ordenam vinte participações em eventos oficiais que, para as análises qualitativas desse estudo, serão divididas em dois períodos: (a) período psicológico pré-interventivo que conjuga os anos 1999, 2000, 2001 e 2002; (b) período psicológico pós-interventido para o ano de 2003. 
TABELA 1 - Participacões em campeonatos oficiais em piscinas de 50 metros na prova dos 100 metros nado Peito no período compreendido entre 1999 e 2003.

\begin{tabular}{|c|c|c|c|c|c|}
\hline Ano & No. & Tempo & Nivel Técnico & Categoria & Classificação \\
\hline 1999 & 01 & 1'18'38 & Estadual & Juvenil & $01^{\circ}$. Lugar \\
\hline 1999 & 02 & 1'19"37 & Estadual & Absoluto & $04^{\circ}$. Lugar \\
\hline 1999 & 03 & $1 ' 18^{n} 07$ & Nacional & Juvenil & $01^{\circ}$. Lugar \\
\hline 1999 & 04 & $1^{\prime} 17^{\prime \prime} 49$ & Estadual & Juvenil & $01^{\circ}$. Lugar \\
\hline 1999 & 05 & $1 ' 18 " 69$ & Nacional & Juvenil & $02^{\circ}$. Lugar \\
\hline 1999 & 06 & $1 ' 18^{\prime \prime} 67$ & Nacional & Absoluto & $14^{\circ}$. Lugar \\
\hline 2000 & 07 & 1'17"18 & Nacional & Juvenil & $01^{\circ}$. Lugar \\
\hline 2000 & 08 & $1 ' 18^{\prime \prime} 90$ & Estadual & Absoluto & $01^{\circ}$. Lugar \\
\hline 2000 & 09 & $1 ' 15^{n} 75$ & Internacional & Juvenil & $02^{\circ}$. Lugar \\
\hline 2000 & 10 & $1 ' 17^{\prime \prime} 19$ & Estadual & Juvenil & $01^{\circ}$. Lugar \\
\hline 2000 & 11 & $1 ' 16 " 65$ & Nacional & Juvenil & $02^{\circ}$. Lugar \\
\hline 2001 & 12 & 1'18"97 & Nacional & Absoluto & $13^{\circ}$. Lugar \\
\hline 2001 & 13 & $1 ' 18^{\prime \prime} 00$ & Nacional & Junior & $02^{\circ}$. Lugar \\
\hline 2001 & 14 & 1'21"93 & Nacional & Junior & $12^{\circ}$. Lugar \\
\hline 2002 & 15 & $1 ' 16^{\prime \prime} 48$ & Nacional & Junior & $03^{\circ}$. Lugar \\
\hline 2002 & 16 & $1^{\prime} 19^{n} 67$ & Estadual & Junior & $01^{\circ}$. Lugar \\
\hline 2003 & 17 & 1'16"17 & Nacional & Junior & $03^{\circ}$. Lugar \\
\hline 2003 & 18 & $1 ' 14 " 94$ & Estadual & Junior & $01^{\circ}$. Lugar \\
\hline 2003 & 19 & $1^{\prime} 14^{n} 88$ & Nacional & Junior & $01^{\circ}$. Lugar \\
\hline 2003 & 20 & $1 ' 14 " 68$ & Estadual & Junior & $01^{\circ}$. Lugar \\
\hline
\end{tabular}

A TABELA 2 demonstra os resultados por temporada esportiva e a média dos tempos para cada período.

TABELA 2 - Demonstrativo dos tempos obtidos e médias por temporadas esportivas que situam o estudo para as análises técnicas qualitativas

\begin{tabular}{rccccc}
\hline No. & 1999 & 2000 & 2001 & 2002 & 2003 \\
\hline $01^{\mathrm{a}}$. & $1^{\prime} 18^{\prime \prime} 38$ & $1^{\prime} 17^{\prime \prime} 18$ & $1^{\prime} 17^{\prime \prime} 19$ & $1^{\prime} 18^{\prime \prime} 97$ & $1^{\prime} 16^{\prime \prime} 17$ \\
$02^{\mathrm{a}}$. & $1^{\prime} 19^{\prime \prime} 39$ & $1^{\prime} 18^{\prime \prime} 90$ & $1^{\prime} 16^{\prime \prime} 65$ & $1^{\prime} 18^{\prime \prime} 00$ & $1^{\prime} 14^{\prime \prime} 94$ \\
$03^{\mathrm{a}}$. & $1^{\prime} 18^{\prime \prime} 07$ & $1^{\prime} 15^{\prime \prime} 75$ & & $1^{\prime} 21^{\prime \prime} 93$ & $1^{\prime} 14^{\prime \prime} 88$ \\
$04^{\mathrm{a}}$. & $1^{\prime} 17^{\prime \prime} 49$ & & & $1^{\prime} 16^{\prime \prime} 48$ & $1^{\prime} 14^{\prime \prime} 68$ \\
$05^{\mathrm{a}}$. & $1^{\prime} 18^{\prime \prime} 69$ & & & $1^{\prime} 19^{\prime \prime} 67$ & \\
$06^{\mathrm{a}}$. & $1^{\prime} 18^{\prime \prime} 67$ & & & & \\
Média & $1^{\prime} 18^{\prime \prime} 45$ & $1^{\prime} 17^{\prime \prime} 28$ & $1^{\prime} 16^{\prime \prime} 92$ & $1^{\prime} 19^{\prime \prime} 01$ & $1^{\prime} 15^{\prime \prime} 17$ \\
\hline
\end{tabular}


As FIGURAS de números 2, 3, 4 e 5 representam as oscilações dos resultados obtidos pela nadadora nas temporadas esportivas dos anos 1999, 2000, 2001 e 2002, respectivamente.

\begin{tabular}{|c|c|c|c|c|c|c|}
\hline Ano 1999 & $01^{\circ}$ & $02^{\circ}$. & $03^{\circ}$. & $04^{\circ}$. & $05^{\circ}$. & $06^{\circ}$. \\
\hline \multicolumn{7}{|l|}{ 1'20" 00} \\
\hline \multicolumn{7}{|l|}{ 1'19" 00} \\
\hline \multicolumn{7}{|l|}{ 1'18" 00} \\
\hline \multicolumn{7}{|l|}{ 1'17" 00} \\
\hline \multicolumn{7}{|l|}{ 1'16" 00} \\
\hline \multicolumn{7}{|l|}{ 1'15" 00} \\
\hline \multicolumn{7}{|l|}{ 1'14" 00} \\
\hline Tempos & $1 / 18^{\prime \prime} 38$ & 1119"39 & $118 " 07$ & 117149 & $118 " 69$ & 118 '67 \\
\hline
\end{tabular}

\begin{tabular}{c}
\hline Oscilação de Tempos \\
Melhor Resultado: \\
1'17"49 \\
Pior Resultado: \\
1'19"39 \\
Oscilação: \\
00'01"90 \\
Média de Tempo: \\
01'18"45
\end{tabular}

FIGURA 2 - Tempos registrados na distância dos 100 metros nado Peito na temporada esportiva do ano $1999 \mathrm{em}$ eventos oficias disputados em piscinas de 50 metros.

A oscilação de tempos ocorrida entre a $1^{\text {a }}$. e $6^{\text {a }}$. participações na temporada de 1999 registrou variações entre o melhor e o pior resultado de um segundo e noventa centésimos de segundo (01s90/100).

\begin{tabular}{|c|c|c|c|}
\hline Ano 2000 & $01^{\circ}$ & $02^{\circ}$. & $03^{\circ}$. \\
\hline 1'20" 00 & & & \\
\hline 1'19" 00 & & & \\
\hline 1'18" 00 & & & \\
\hline 1 '17" 00 & & & \\
\hline 1'16" 00 & & & \\
\hline 1'15" 00 & & & \\
\hline 1'14" 00 & & & \\
\hline Tempos & $1: 17 " 18$ & 1'18"90 & 11577 \\
\hline
\end{tabular}

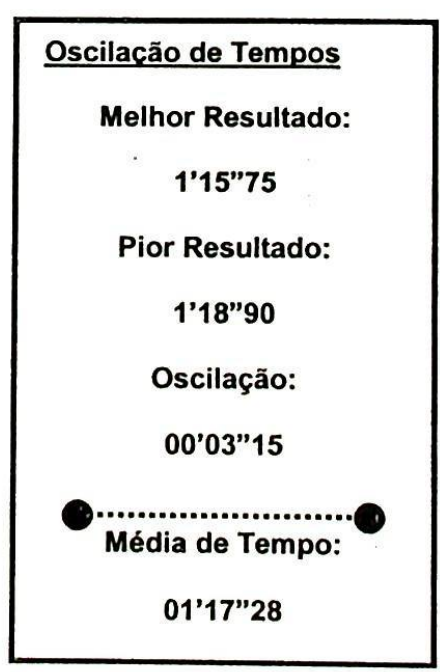

FIGURA 3 - Tempos registrados na distância dos 100 metros nado Peito em eventos oficiais no ano de $2000 \mathrm{em}$ piscinas de 50 metros. 
A oscilação de tempos ocorrida entre a $1^{a}$. e $3^{a}$. participações na temporada de 2000 registrou variações entre o melhor e o pior resultado de três segundos e quinze centésimos de segundo (03s15/100).

O desempenho técnico ocorrido em um evento de nivel internacional, com a marca de 1'15"75 (um minuto e quinze segundos e setenta e cinco centésimos), alçou a nadadora para o grupo das principais atletas do pais na distância, marcando significativamente sua carreira esportiva.

Esse resultado tem um significado psicológico relevante para a nadadora e para o estudo.

Em decorrência desse resultado, o status adquirido pela nadadora modificou de modo significativo a sua situação grupal esportiva, sócio-familiar e pessoal.

Os resultados esportivos tecnicamente relevantes possibilitam uma exposição do atleta junto à mídia e, como uma das conseqüências, a aproximação dos patrocinadores, programas de preparações e atenções individualizadas pela Comissão Técnica, principalmente por parte do treinador, de dirigentes e familiares. Em decorrência dessas situações no campo esportivo, os atletas são levados à mudanças no curso das suas carreiras e das próprias vidas.

O resultado esportivo é objeto de desejo permanente dos atletas e de todo o seu entorno.

\begin{tabular}{|c|c|c|}
\hline Ano 2001 & $01^{\circ}$. & $02^{\circ}$. \\
\hline $1 ' 20$ " 00 & & \\
\hline 1'19" 00 & & \\
\hline 1'18" 00 & ๑ & \\
\hline 1'17" 00 & & \\
\hline 1'16" 00 & & $\Delta$ \\
\hline 1'15" 00 & & \\
\hline 1'14" 00 & & \\
\hline Tempos & $1417^{\prime \prime} 19$ & $1^{\prime} 16^{\prime \prime} 65$ \\
\hline
\end{tabular}

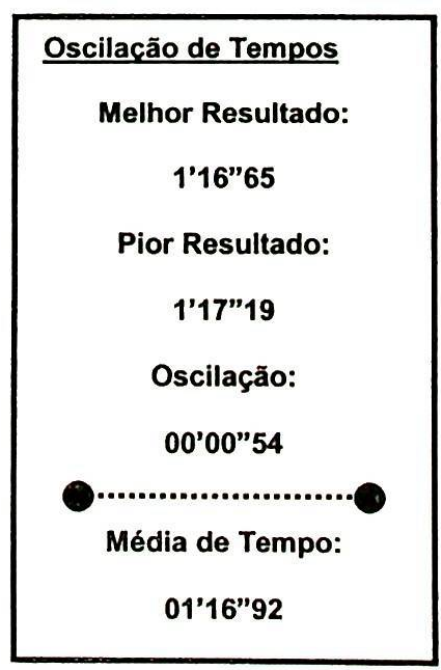

FIGURA 4 -Tempos registrados na distância dos 100 metros nado Peito em eventos oficiais no ano de 2001 em piscinas de 50 metros. 
A oscilação de tempos ocorrida entre a $1^{\mathrm{a}}$. e $2^{\mathrm{a}}$. participações na temporada de 2001 registrou variações entre o melhor e o pior resultado de cinqüenta e quatro centésimos de segundo (00s54/100).

\begin{tabular}{|c|c|c|c|c|c|}
\hline Ano 2002 & $01^{\circ}$. & $02^{\circ}$. & $03^{\circ}$ & $04^{\circ}$. & $05^{\circ}$ \\
\hline 1'22" 00 & & & & & \\
\hline 1'21" 00 & & & & & \\
\hline $1 ' 20 " 00$ & & & & & \\
\hline 1'19" 00 & & & & & \\
\hline 1'18" 00 & & & & & \\
\hline 1'17" 00 & & & & & \\
\hline 1'16" 00 & & & & & \\
\hline 1'15" 00 & & & & & \\
\hline 1'14" 00 & & & & & \\
\hline Tempos & $1 / 18797$ & $118 \% 00$ & $121 " 93$ & $116^{\prime \prime} 48$ & 1'19"67 \\
\hline
\end{tabular}

\begin{tabular}{|c|}
\hline Oscilacão de Tempos \\
Melhor Resultado: \\
1'16"48 \\
Pior Resultado: \\
1'21"93 \\
Oscilação: \\
00 '06"45 \\
Média de................ Tempo: \\
01'19"67
\end{tabular}

FIGURA 5 - Tempos registrados na distância dos 100 metros nado Peito em eventos oficiais no ano de $2002 \mathrm{em}$ piscinas de 50 metros.

A oscilação de tempos ocorrida entre a $1^{\text {a }}$. e $5^{\text {a }}$. participações na temporada de 2002 registrou variações entre o melhor e o pior resultado de seis segundos e quarenta e cinco centésimos de segundo (06s45/100).

Pode-se observar que as participações da temporada de 2002 foram marcas por atuações com grande disparidade nas performances.

\section{Período crítico}

Essa temporada esportiva foi considerada para esse estudo, como a fase mais crítica sob a ótica psicológica. A não melhora de tempo evidenciou os conflitos relacionados aos objetivos esportivos, principalmente com relação à realidade $\mathrm{e}$ temporalidade e foco dos mesmos.

A FIGURA 6 demonstra as oscilações dos tempos entre os melhores e piores resultados por anos competitivo, relacionados para esse estudo. 


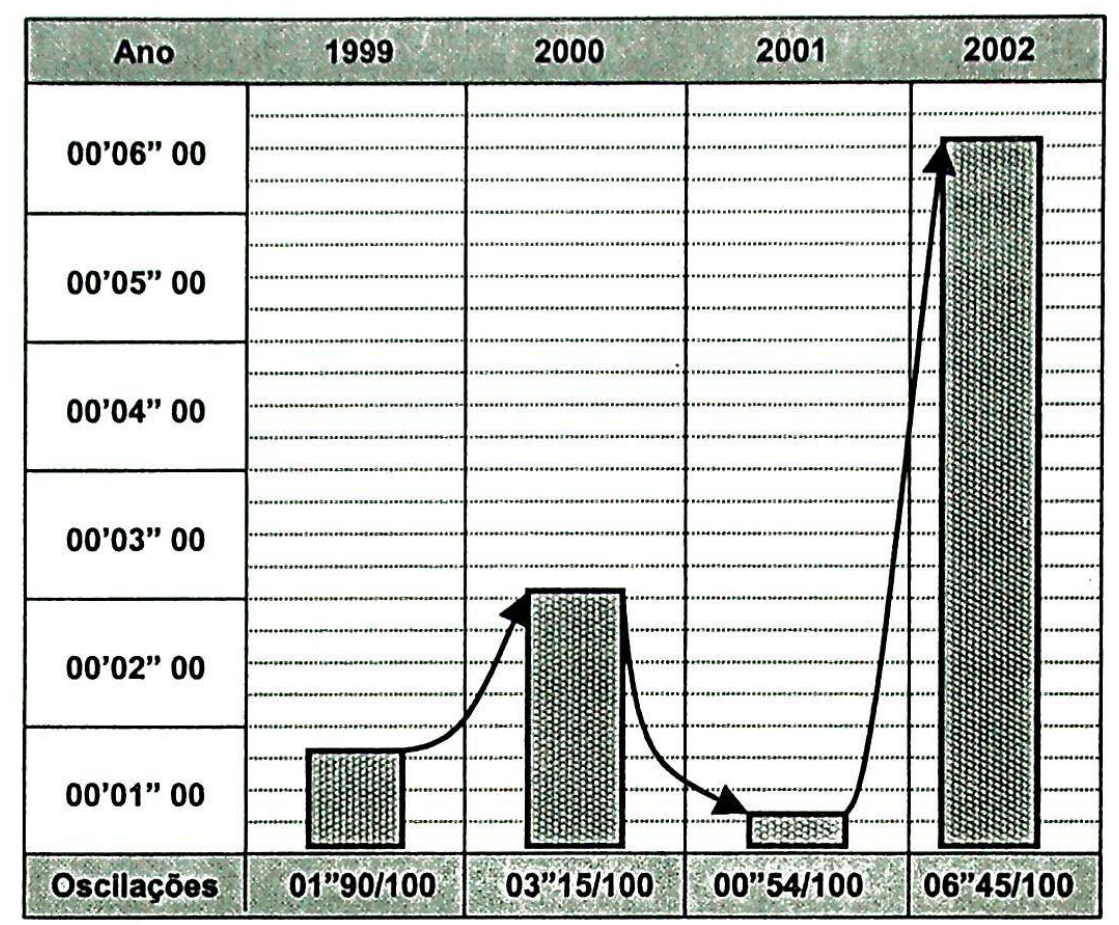

FIGURA 6 - Oscilacões de tempos entre os melhores e os piores resultados por temporadas esportivas - 1999/2002

Análise técnica das fases A, B, C do período pré-interventivo

As participações esportivas da nadadora na prova dos 100 metros nado Peito foram dividas em três períodos para esse estudo, compreendendo as temporadas de 1999, 2000, 2001 e 2002. Essa divisão por fases, objetiva agrupar três momentos distintos no percurso da nadadora, sendo que cada uma das fases compreende situações relevantes nos aspectos psicológicos da atleta, no período que antecedeu as intervenções psicológicas esportivas, denominado de período préinterventivo.

Os tempos médios, velocidades e porcentagens de desempenhos em relação à melhor performance de cada fases pré-interventiva, demonstram a evolução técnico-competitiva na distância dos 100 metros nado peito, conforme demonstrada na TABELA 3. 
TABELA 3 - Análise de desempenho técnico das Fases A, B e C do período pré-interventivo.

\begin{tabular}{|c|c|c|c|c|}
\hline Ano & Participação & Tempo & $\begin{array}{l}\text { Velocidade } \\
\text { Metros/seg }\end{array}$ & $\%$ de $1 ' 15^{\prime \prime} 75$ (B) \\
\hline & & Fase A & & \\
\hline 1999 & $01^{\mathrm{a}}$. & 1'18"38 & $1.27,58 \mathrm{~m} / \mathrm{s}$ & $3,355 \%$ \\
\hline 1999 & $02^{\mathrm{a}}$. & 1'19"37 & $1.25,99 \mathrm{~m} / \mathrm{s}$ & $4,560 \%$ \\
\hline 1999 & $03^{\mathrm{a}}$. & $1 ' 18 " 07$ & $1.28,09 \mathrm{~m} / \mathrm{s}$ & $2,971 \%$ \\
\hline 1999 & $04^{\mathrm{a}}$. & 1'17"49 & $1.29,04 \mathrm{~m} / \mathrm{s}$ & $2,245 \%$ \\
\hline 1999 & $05^{\mathrm{a}}$. & 1'18"69 & $1.27,08 \mathrm{~m} / \mathrm{s}$ & $3,736 \%$ \\
\hline 1999 & $06^{\mathrm{a}}$. & 1'18"67 & $1.27,11 \mathrm{~m} / \mathrm{s}$ & $3,711 \%$ \\
\hline 2000 & $07^{\mathrm{a}}$. & 1'17'18 & $1.29,56 \mathrm{~m} / \mathrm{s}$ & $1,852 \%$ \\
\hline \multirow[t]{3}{*}{2000} & $08^{\mathrm{a}}$. & $1 ' 18 " 90$ & $1.26,74 \mathrm{~m} / \mathrm{s}$ & $3,992 \%$ \\
\hline & $\begin{array}{c}\text { Total de } \\
\text { atuações Fase A } \\
08\end{array}$ & $\begin{array}{c}\text { Tempo Médio: } \\
\text { 1'18"34 }\end{array}$ & $\begin{array}{l}\text { Velo. Média } \\
1.27,64 \mathrm{~m} / \mathrm{s}\end{array}$ & $\begin{array}{c}\text { Média (\%) } \\
3,306 \%\end{array}$ \\
\hline & & Fase B & & \\
\hline \multirow[t]{3}{*}{2000} & $09^{2}$ & 1'15'75 & $1.32,01 \mathrm{~m} / \mathrm{s}$ & $100 \%$ \\
\hline & $\begin{array}{c}\text { Total de } \\
\text { atuações } \\
\text { Fase B } \\
08 \\
\end{array}$ & $\begin{array}{l}\text { Tempo Médio: } \\
\text { 1'15"75 }\end{array}$ & $\begin{array}{l}\text { Velo. Média } \\
1.32,01 \mathrm{~m} / \mathrm{s}\end{array}$ & $\begin{array}{l}\text { Média (\%) } \\
100\end{array}$ \\
\hline & & Fase C & & \\
\hline 2000 & $10^{\mathrm{a}}$. & 1'17"19 & $1.29,55 \mathrm{~m} / \mathrm{s}$ & $1,865 \%$ \\
\hline 2000 & $11^{\mathrm{a}}$. & $1 ' 16 " 65$ & $1.29,92 \mathrm{~m} / \mathrm{s}$ & $1.174 \%$ \\
\hline 2001 & $12^{\mathrm{a}}$. & 1'18"97 & $1.26,63 \mathrm{~m} / \mathrm{s}$ & $4.077 \%$ \\
\hline 2001 & $13^{\mathrm{a}}$. & $1 ' 18 " 00$ & $1.28,20 \mathrm{~m} / \mathrm{s}$ & $2.884 \%$ \\
\hline 2001 & $14^{\mathrm{a}}$. & 1'21"93 & $1.22,05 \mathrm{~m} / \mathrm{s}$ & $7.543 \%$ \\
\hline 2002 & $15^{\mathrm{a}}$. & $1 ' 16 " 48$ & $1.30,75 \mathrm{~m} / \mathrm{s}$ & $0.954 \%$ \\
\hline \multirow[t]{2}{*}{2002} & $16^{a}$. & 1'19"67 & $1.25,51 \mathrm{~m} / \mathrm{s}$ & $4.920 \%$ \\
\hline & $\begin{array}{c}\text { Total de } \\
\text { atuações Fase C } \\
07\end{array}$ & $\begin{array}{c}\text { Tempo Médio } \\
18^{\prime \prime 41}\end{array}$ & $\begin{array}{l}\text { Velo. Média } \\
1.27,51 \mathrm{~m} / \mathrm{s}\end{array}$ & $\begin{array}{c}\text { Média (\%) } \\
3,329 \%\end{array}$ \\
\hline
\end{tabular}

A FIGURA 7 condensa os resultados das atuações compreendidas entre os anos de 1999 e 2002 denominadas para esse estudo com período pré-interventivo. Esse período foi dividido em três fases: Fase A, Fase B e Fase C. 


\begin{tabular}{|c|c|c|c|c|c|c|c|c|c|c|c|c|c|c|c|c|}
\hline Ano & & & \multicolumn{2}{|c|}{1999} & \multirow[b]{2}{*}{$5 / 5$} & \multirow[b]{2}{*}{$6 / 6$} & \multirow[b]{2}{*}{711} & \multicolumn{3}{|c|}{2000} & \multicolumn{3}{|c|}{2001} & \multicolumn{3}{|c|}{2002} \\
\hline Atuacóes & $1 / 1$ & $2 / 2$ & $3 / 3$ & $4 / 4$ & & & & $8 / 2$ & $9^{9 / 3}$ & 1014 & $1 / 5$ & 1211 & $13 / 2$ & & $5 / 1$ & $16 / 2$ \\
\hline $11^{\prime \prime 2} 00$ & & & A & & & & & & B & & & & C & & & \\
\hline $1 ' 20 " 00$ & & & & & & & & & & & & & & & & \\
\hline $1 ' 19^{\prime \prime} 00$ & & & & & & & & & & & & & & & & \\
\hline 1'18"00 & & & & & & & & & & & & & & & & \\
\hline 1'17"00 & & & & & & & & & & & & & & & & \\
\hline $1 ' 16^{\prime \prime} 00$ & & & & & & & & & & & & & & & V & \\
\hline $1^{\prime} 15^{\prime \prime} 00$ & & & & & & & & & & & & & & & & \\
\hline 1'14"00 & & & & & & & & & i & & & & & & & \\
\hline $1{ }^{\prime} 13^{\prime \prime} 00$ & & & & & & & & & ! & & & & & & & \\
\hline 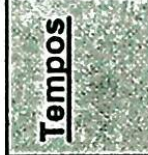 & 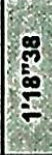 & $\hat{\rho}$ & i & $\frac{9}{7}$ & : & $\begin{array}{l}5 \\
0 \\
\end{array}$ & $\frac{\infty}{2}$ & $\delta_{5}^{8}$ & 15 & $\sqrt{3}$ & $\begin{array}{l}0 \\
0 \\
0 \\
0\end{array}$ & बे & $\begin{array}{l}8 \\
\infty \\
-\end{array}$ & $\begin{array}{l}\frac{8}{9} \\
\text { a } \\
\text { N }\end{array}$ & 9 & $\begin{array}{l}0 \\
0 \\
\sigma\end{array}$ \\
\hline
\end{tabular}

FIGURA 7 - Tempos obtidos nos 100 metros nado Peito no período pré-interventivo

\section{Fase A}

A fase A compreendeu o percurso de oito atuações em campeonatos na prova dos 100 metros nado Peito em piscinas de 50 metros, iniciado no ano de 1999 e parte do ano de 2000. Nessa fase a nadadora já despontava com destaque nas competições da sua categoria, não demonstrando sinais comportamentais e psicológicos de conflitos relacionados aos seus objetivos esportivos, conforme relatos descritos no QUADRO 1.

A FIGURA 8 e TABELA 4 contém as oscilações dos resultados e médias de tempos, velocidades e percentagens de melhoras e pioras de performances, respectivamente, nesse período. 


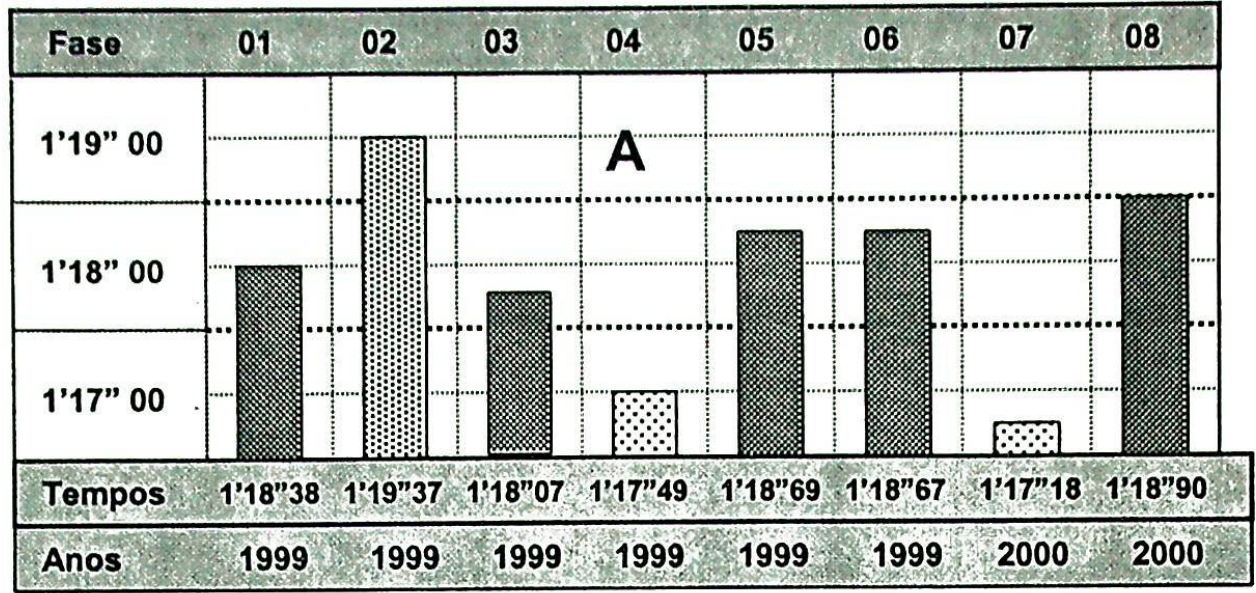

Performance estabilizada

Performance piorada

Performance melhorada

FIGURA 8 - Demonstrativo de melhora, estabilidade e piora de performance na prova dos 100 metros nado Peito na Fase $A$ do período pré-interventivo

TABELA 4 - Análise de desempenho técnico da fase A do periodo pré-interventivo

\begin{tabular}{|c|c|c|c|c|}
\hline \multicolumn{5}{|c|}{ Fase A } \\
\hline Ano & Participação & Tempo & Metros/Seg & $(\%)$ \\
\hline 1999 & $1^{a}$ & 1'18'38 & $1.27,58 \mathrm{~m} / \mathrm{s}$ & $100 \%$ \\
\hline 1999 & $2^{\mathrm{a}}$ & 1'19"37 & $1.25,99 \mathrm{~m} / \mathrm{s}$ & $>1,263 \%$ \\
\hline 1999 & $3^{a}$. & 1'18"07 & $1.28,09 \mathrm{~m} / \mathrm{s}$ & $<0,395 \%$ \\
\hline 1999 & $4^{\mathrm{a}}$. & 1'17"49 & $1.29,04 \mathrm{~m} / \mathrm{s}$ & $<1,135 \%$ \\
\hline 1999 & $5^{a}$ & 1'18"69 & $1.27,08 \mathrm{~m} / \mathrm{s}$ & $>0,395 \%$ \\
\hline 1999 & $6^{\mathrm{a}}$ & 1'18"67 & $1.27,11 \mathrm{~m} / \mathrm{s}$ & $>0,369 \%$ \\
\hline 2000 & $7^{\mathrm{a}}$. & 1'17"18 & $1.29,56 \mathrm{~m} / \mathrm{s}$ & $<1,531 \%$ \\
\hline \multirow[t]{2}{*}{2000} & $\begin{array}{c}8^{a} \\
\text { Total de }\end{array}$ & $1 ' 18 " 90$ & $1.26,74 \mathrm{~m} / \mathrm{s}$ & $>0,663 \%$ \\
\hline & $\begin{array}{c}\text { atuações Fase } \\
\text { A } \\
08\end{array}$ & $\begin{array}{l}\text { Tempo Médio: } \\
\text { 1'18"34 }\end{array}$ & $\begin{array}{l}\text { Velo. Média } \\
1.27,64 \mathrm{~m} / \mathrm{s}\end{array}$ & $\begin{array}{c}<(\%) \\
0,371 \%\end{array}$ \\
\hline
\end{tabular}

Embora considerando a precisão das aferições de tempos na modalidade onde o placar eletrônico atua na casa dos centésimos de segundos (1"/100), sendo, portanto, possivel em um único segundo (00:00:01:00) classificar 100 atletas, para a análise da atitude competitiva, foco central dos aspectos psicológicos objetivados nesses estudo, a pouca oscilação das marcas, cujos percentuais para melhor ou pior não chegam a 1,00 \% caracterizam um processo de estabilidade. Essas diferenças, embora significativas no ponto de vista técnico, na variável psicológica no que se 
refere à atitude competitiva combativa não são relevantes principalmente quando se analisa o discurso da nadadora referente a esse período.

Nessa fase que compreendeu oito atuações a nadadora permaneceu com a marca estabilizada na casa de $1^{\prime} 18^{\prime \prime} 00$ (um minuto e dezoito segundos) nas $1^{\text {a }}$.

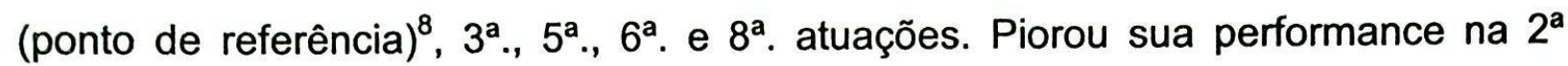
participação. Obtendo melhoras no $4^{\circ}$. e $7^{\circ}$. eventos. TABELA 5.

As variações percentuais de estabilidade podem ser observadas na

TABELA 5 - Performances da Fase A consideradas estabilizadas

\begin{tabular}{|c|c|c|c|c|}
\hline Atuação & Ano & Tempo & Referência & Porcentagem \\
\hline $1^{2}$. & 1999 & 1'18'38 & $=$ & $100 \%$ \\
\hline $3^{a}$. & 1999 & 1'18"07 & $<$ & $0,395 \%$ \\
\hline $5^{a}$ & 1999 & 1'18"69 & $>$ & $0,395 \%$ \\
\hline $6^{a}$. & 1999 & 1'18"67 & $>$ & $0,369 \%$ \\
\hline $8^{a}$. & 2000 & 1'18"90 & $>$ & $0,663 \%$ \\
\hline
\end{tabular}

Foi considerada como performance piorada na Fase $\mathrm{A}$ a $2^{\mathrm{a}}$. atuação com o tempo de 1'19"37 por ter superada a caso dos 1'18"00 e estando a marca mais de $1,00 \%$ pior.

A TABELA 6 mostra a variação percentual dessa atuação.

TABELA 6 - Performance da Fase A considerada piorada

\begin{tabular}{ccccc}
\hline Atuação & Ano & Tempo & Referência & Porcentagem \\
\hline $1^{\mathrm{a}}$. & 1999 & $1^{\prime} 18^{\prime \prime} 38$ & $=$ & $100 \%$ \\
$2^{\mathrm{a}}$ & 1999 & $1^{\prime} 19^{\prime \prime} 37$ & $>$ & $1,263 \%$ \\
\hline
\end{tabular}

Foi considerada como performance melhorada na Fase $A$ os tempos superiores a 1'18"00. Essas marcas podem ser observadas nas $4^{\mathrm{a}}$. e $7^{\text {a }}$.participações.

A TABELA 7 mostra as variações percentuais melhoras nessas performances, ficando essas atuações mais de 1,00 \% melhores em relação ao tempo de 1'18"00.

\footnotetext{
${ }^{8}$ Essa primeira marca $\left(1^{\prime} 18^{\prime \prime} 38\right)$ será utilizada como ponto inicial (partida) para as análises técnicas desse estudo.
} 
TABELA 7 - Performances da Fase A consideradas melhoradas

\begin{tabular}{ccccc}
\hline Atuação & Ano & Tempo & Referência & Porcentagem \\
\hline $\mathbf{1}^{\mathrm{a}} \mathrm{a}$ & $\mathbf{1 9 9 9}$ & $\mathbf{1}^{\prime} 18^{\prime \prime} 38$ & $=$ & $100 \%$ \\
$4^{\mathrm{a}}$ a & 1999 & $1^{\prime} 17^{\prime \prime} 49$ & $<$ & $1,135 \%$ \\
$\mathbf{7}^{\mathrm{a}}$. & 2000 & $1^{\prime} 17^{\prime \prime} 18$ & $<$ & $1,531 \%$ \\
\hline
\end{tabular}

\section{A Fase B}

A fase B foi caracterizada nesse estudo como o ponto relevante na carreira da nadadora. Com o registro da marca de um minuto e quinze segundos e setenta e cinco centésimos de segundo $\left(01^{\prime}{ }^{\prime} 5^{\prime \prime} 75\right)$ a atleta aos 16 anos, obteve o destaque esportivo que interferiu de modo significativo na sua trajetória. Essa marca foi na ocasião, uma das melhores registradas, na distância, pelas mulheres da natação brasileira. Os aspectos psicológicos dessa marca estão contidos nas análises dos discursos demonstrados no QUADRO 2.

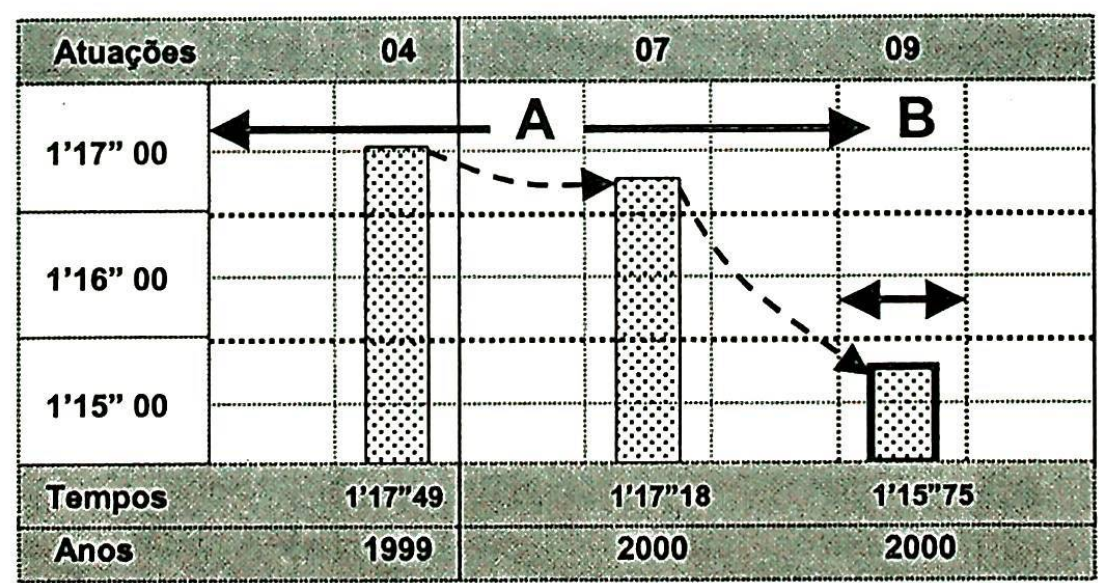

Performance melhorada

FIGURA 9 - Demonstrativo das melhoras de tempos das Fases A e B

$\mathrm{Na} 9^{\mathrm{a}}$. atuação registrada no ano de 2000 a nadadora obteve a marca de um minuto e quinze segundos e setenta e cinco centésimos de segundos (1'15"75) considerada na temporada como a melhor marca do ano em todas as categorias no ranking nacional. 
TABELA 8 - Demonstrativo de melhoras de performances da Fase A para a Fase B

\begin{tabular}{cccccc}
\hline Ano & Fases & Atuação & Tempo & $<\%$ & \% de Melhora \\
\hline 1999 & A & $4^{\text {a. }}$ & $1^{\prime} 17^{\prime \prime} 49$ & $100 \%$ & \\
2000 & A & $7^{\text {a }}$ & $1^{\prime} 17^{\prime \prime} 18$ & $99,59 \%$ & $0,40 \%$ \\
2000 & B & $9^{\text {a. }}$ & $1^{\prime} 15^{\prime \prime} 75$ & $98,14 \%$ & $1,85 \%$ \\
\hline
\end{tabular}

A FIGURA 10 a performance melhorada para a marca de 1'15"75 da Fase $B$ em ralação às performances anteriores, obtidas na Fase $A$.

\begin{tabular}{|c|c|c|c|c|c|c|c|c|c|}
\hline Fases & A 012 & $02^{2}$ & $03^{\circ}$ & $04^{\circ}$ & $05^{2}$ & $06^{\circ}$ & $07^{a}$ & $08^{\circ}$ & B $09^{2}$ \\
\hline \multirow{3}{*}{ 1'19" 00} & & & & & & & & & \\
\hline & & & & $\mathbf{A}$ & & & & & B \\
\hline & & & & & & .. & 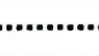 & & 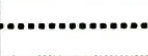 \\
\hline \multicolumn{10}{|l|}{ 1'18" 00} \\
\hline \multirow{2}{*}{\multicolumn{10}{|c|}{ 1'17" 00}} \\
\hline & & & & & & & & & \\
\hline \multicolumn{10}{|l|}{ 1'16" 00} \\
\hline \multicolumn{10}{|l|}{1 '15" 00} \\
\hline Tompos & $118^{178}$ & $19^{\prime \prime} 37$ & $18^{\prime \prime} 07$ & $17^{\prime 4} 49$ & 118769 & $18^{\prime \prime} 67$ & 1171 & 1118"90 & $115^{2} 75$ \\
\hline
\end{tabular}

Performance estabilizada

Performance piorada

Performance melhorada

FIGURA 10 - Comparativo qualitativo das Fases A e B

A TABELA 9 demonstra os ganhos qualitativos da nadadora com a obtenção da marca de 1'15"75.

TABELA 9 - Análise de desempenho técnico da Fase B do período pré-interventivo

\begin{tabular}{ccccc}
\hline Ano & Atuação & Fase B & Velocidade & $\%$ de Melhora \\
\hline 2000 & $9^{\text {a }}$ & $1 ' 15 " 75$ & $1.32,01 \mathrm{~m} / \mathrm{s}$ & $100 \%$ \\
& Total de atuações & Tempo Médio: & Velo. Média & Média (\%) \\
& Fase B & 1 '15"75 & $1.32,01 \mathrm{~m} / \mathrm{s}$ & 100 \\
& 08 & & & \\
\hline
\end{tabular}


A FIGURA 11 correlaciona o melhor desempenho da nadadora então obtido na $6^{\mathrm{a}}$. atuação quando auferiu o tempo de 1'17"18 com a nova marca.

\begin{tabular}{|c|c|c|c|}
\hline Ano 2000 & $07^{\circ}$ & & $09^{2}$ \\
\hline 1'17" 00 & & & \\
\hline & & & B \\
\hline $116 " 00$ & & ( & \\
\hline & & & \\
\hline 1'15" 00 & & & m \\
\hline Tempos & \multicolumn{2}{|c|}{$117^{\prime \prime} 18$} & $1115^{\prime \prime} 75$ \\
\hline
\end{tabular}

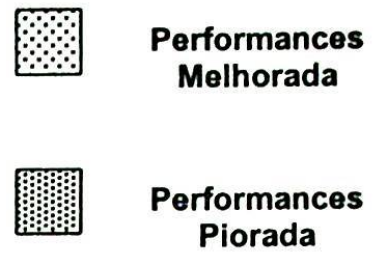

FIGURA 11 - Representacão da melhora de desempenho nas participacões $\underline{07^{\mathrm{a}}(\mathrm{B}) \text { e } 09^{\mathrm{a}}(\mathrm{B})}$

TABELA 10 - Demonstrativo dos ganhos qualitativos do resultado da Fase $B$ em relacão ao melhor tempo da Fase $A$

\begin{tabular}{ccrrrrr}
\hline Fase & No. & Tempo & \multicolumn{1}{c}{$\mathrm{m} / \mathrm{s}$} & $\%$ & $\mathrm{~m}$ & Velo. $>\mathbf{c m} / \mathbf{m}$ \\
\hline A & $07^{\mathrm{a}}{ }^{\circ}$ & $1^{\prime} 17^{\prime \prime} 18$ & $1.29,56$ & 100 & 0 & \\
B & $09^{\mathrm{a}}$. & $1^{\prime} 15^{\prime \prime} 75$ & $1.32,01$ & $>1,85$ & $>1,89$ & 1,89 \\
& & $-0^{\prime} 01^{\prime \prime} 43$ & 02,45 & & & \\
\hline
\end{tabular}

\section{A Fase C}

A fase C compreendeu as atuações de 10 a 16 conforme TABELA 1. Esses resultados tiveram início no mesmo ano esportivo de 2000 imediatamente após o resultado obtido na $09^{\mathrm{a}}$. atuação. Observa-se nesse período que compreendeu parte do ano de 2000 e todas as imediatas temporadas esportivas de 2001 e 2002 uma inconstância nas marcas obtidas pela nadadora.

Essa fase, considerada crítica nesse estudo perante oscilações de tempos para pior de até seis segundos e quarenta e cinco centésimos de segundo (06"45/100) , culmina com o registro do tempo de um minuto e dezenove segundos e sessenta e sete centésimos de segundos (01'19"67) obtidos na $19^{\mathrm{a}}$. participação (TABELA 1). Completa, dessa forma, o período pré-interventivo. 
Com esses resultados a nadadora permaneceu por um período de dois anos e seis meses sem igualar ${ }^{9}$ ou melhorar as suas marcas, em se tratando de registros de tempos, independente das suas colocações no pódio.

Esse resultados podem ser observados na FIGURA 9 que reúne todos os resultados da fase $\mathrm{C}$.

\section{Período crítico}

Ao longo de duas e meia temporadas esportivas, parte do ano de $2000 \mathrm{e}$ anos completos de 2001 e 2002, a nadadora alterou a atitude competitiva sem motivos aparentes. Embora tenha treinado normalmente, conforme entrevistas com a Comissão Técnica, a nadadora passou a não apresentar o mesmo entusiasmo e atitude competitiva que a vinha caracterizando até então.

Os exames clínicos, rotineiramente executados pela atleta, não apontavam nenhuma causa física que pudesse justificar as reações comportamentais competitivas apresentadas pela atleta nessa fase.

Esse período concentra um conteúdo psicológico importante para a pesquisa em razão das oscilações acentuadas, sem motivos aparentes, nos resultados competitivos.

Na FIGURA 12 estão contidos os resultados piorados obtidos nas temporadas de 2000, 2001 e 2002.

${ }^{9}$ Embora o termo usual igular referir-se às repetições dos tempos obtidos pelos nadadores ser comum no jargão esportivo, no que se refere à existência vivencial, por ser única, a repetição jamais ocorrerá 


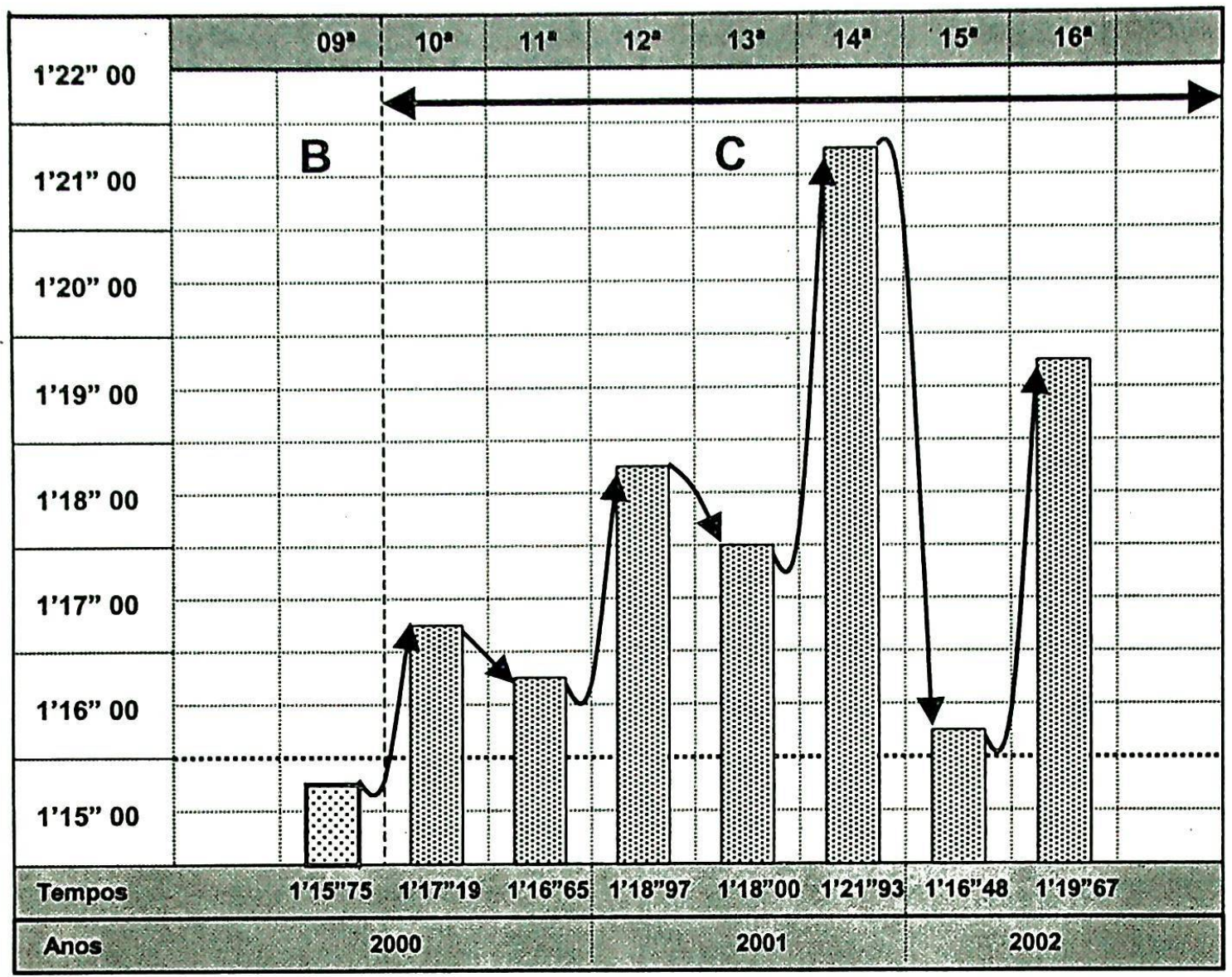

Melhor Tempo

Performance piorada

FIGURA 12 - Resultados competitivos da segunda metade da temporada de 2000 e temporadas completas de 2001 e 2002

\subsection{Observação sistemática nos treinamentos e nas competições}

A atleta foi acompanhada durante as sessões de treinamentos e nas principais competições de niveis estaduais e nacionais realizadas em piscinas de 50 metros realizadas nos anos de 2003 e 2004.

Nos treinamentos e nas competições, foram observados os seguintes aspectos de respostas fisiológicos e atitudinais: o controle dos ritmos para o desenvolvimento das capacidades aeróbias divididas em A1 (onde as intensidades eram situadas entre 2 e $3 \mathrm{mM} / \mathrm{l}$ de acúmulo de ácido lático, ritmo cardíaco de 120 a

em razão das competições ocorrerem em momentos distintos da vida do atleta independente dos locais onde esses eventos ocorram. 
$150 \mathrm{bpm}$ priorizando melhor a resistência da capacidade de circulação central) , A2 (onde as intensidades situavam-se entre 3 e $4 \mathrm{mM} / \mathrm{l}$ de acúmulo de ácido lático sangüíneo, ritmo cardíaco de 150 a 170 bpm priorizando a resistência localizada dos gestos natatórios) e A3 (com intensidades situadas em 5 e $6 \mathrm{mM} / \mathrm{l}$ de lactacidemia, ritmo cardíaco de 170 a 190 bpm priorizando o desenvolvimento e manutenção do $\mathrm{VO}_{2}$ Máximo) e séries de tolerância de lactato e controle de glicemia.

Essas tarefas específicas eram distribuídas nos micro-ciclos, ao longo do programa semestral, nas suas fases de base para o desenvolvimento geral, fase do desenvolvimento específico das provas principais e polimento que se traduz em um momento psicológico complexo de preparação competitiva. Durante a realização dessas tarefas específicas de grande intensidade e desgaste tanto de ordem física como psicológica, a nadadora correspondeu as expectativas dos treinadores, sem demonstrar alterações comportamentais relevantes que a tirasse da normalidade referentes aos demais componentes da equipe. À media em que a nadadora ia realizando os seus treinamentos, em todas as suas fases, seu comportamento foi observado, principalmente nas sessões que trabalhavam as energias específicas da prova como nas séries de tolerância de lactato e ritmos de prova. Essas sessões ocorreram de uma a duas vezes em cada micro-ciclo da fase especíica que totalizavam de quatro a seis semanas.

O técnico responsável pela preparação da atleta durante as sessões de treinamentos especificos, controlou sistematicamente o ritmo das execuções dos atletas conjuntamente com os seus auxiliares. Os contatos com a nadadora, por ocasião das execuções qualitativas das sessões de treinamento em dias específicos, ocorriam no ambiente da piscina momentos antes do início dos treinamentos e logo após o encerramento dos mesmos. Nessas ocasiões, a nadadora relatou suas impressões referentes às sensações tanto físicas como psicológicas para aqueles momentos.

O QUADRO 2 registra algumas das principais séries executadas pela nadadora nos períodos específicos do programas de preparação. As velocidades de execuções dessas tarefas se intensificavam uma vez que ocorriam as adaptações orgânicas. Dessa forma as capacidades fisiológicas podiam ser aferidas pela CT. 
QUADRO 2-Exemplos de series de treinamentos para melhora das capacidades técnicas e fisiológicas

\begin{tabular}{|c|c|}
\hline Série Aeróbia 1 & Série Aeróbias 2 \\
\hline 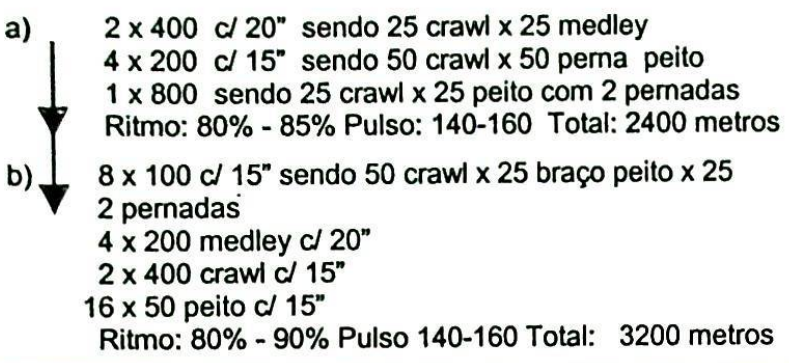 & 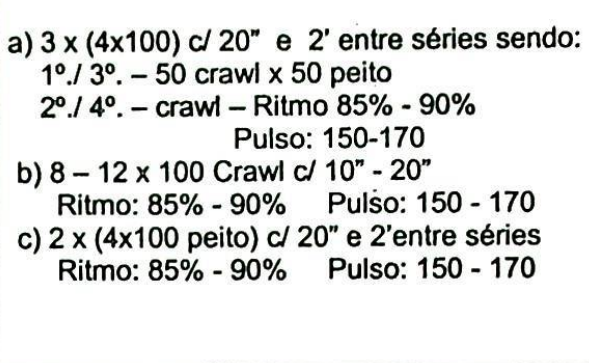 \\
\hline Séries Aeróbia 3 & Séries de Tolerância de Lactato \\
\hline $\begin{array}{l}\text { a) } 3 \times 200 \text { crawl c/ 30" Ritmo: } 85 \%-90 \%-95 \% \\
\text { b) } 4 \times 100 \text { peito c/ 30" Ritmo: } 85 \%-90 \%-95 \%\end{array}$ & $\begin{array}{l}\text { a) } 4 \times(4 \times 50) \text { peito } c / 3^{\prime} \text { (min) de intervalo } \\
\text { b) } 4 \times 75 \text { peito } c / 3^{\prime}-5^{\prime} \text { de intervalo } \\
\text { c) } 4 \times 100 \mathrm{c} / 5^{\prime}-10^{\prime} \text { de intervalo }\end{array}$ \\
\hline
\end{tabular}

O QUADRO 3 registra alguns exemplos de séries executadas pela nadadora para a melhora das suas capacidades técnicas e fisiológicas.

\section{QUADRO 3 - Exemplos de sereis de treinamentos para melhora das capacidades técnicas e} Fisiológicas

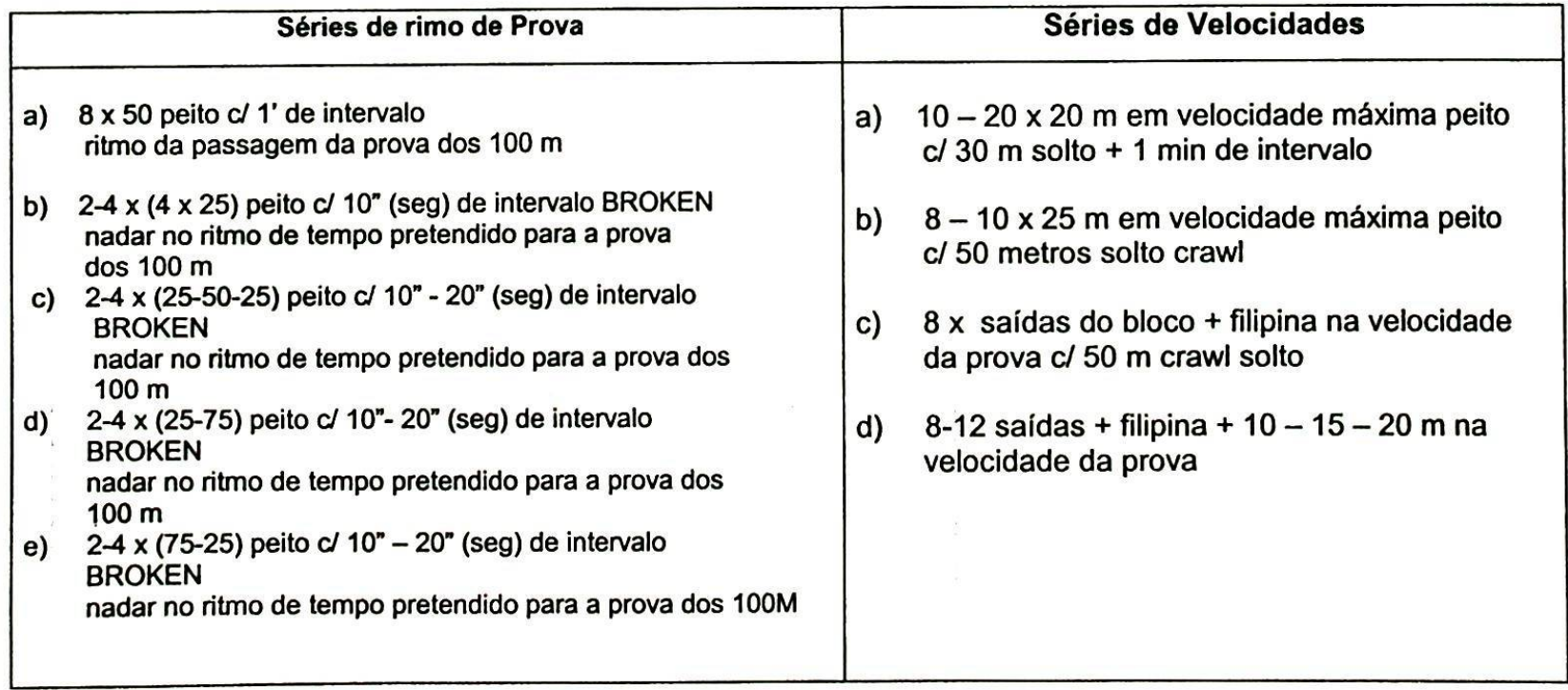

Durante as execuções dos treinamentos a nadadora sempre interagiu com o grupo e com CT, procurando desenvolver os ritmos dentro das solicitações dos treinadores.

Vários treinamentos foram executados ao longo do período das observações desse trabalho. Tornar-se-ia inviável e mesmo desnecessário a 
descrição de todas as execuções efetuadas, tendo em vista o objetivo da pesquisa centrar-se nos aspectos psicológicos relacionados aos conflitos de objetivos $\mathrm{e}$ as suas atitudes nos treinamentos. Durantes as sessões de treinamento, a nadadora sempre se mostrou motivada e participativa. O cansaço evidenciava-se, como era esperado, à medida em que a intensidade dos treinamentos iam se intensificando nas várias fases do programa de preparação.

Nessas ocasiões as oscilações de humor ficavam evidentes e, em muitas ocasiões extrapolavam às questões relacionadas ao ambiente esportivo. Situações de ordem pessoal também foram abordadas à media que iam surgindo como um processo natural do transcurso das intervenções e solidificação do vínculo com a nadadora.

Um aspecto importante, porém, foi verificar os resultados das análises dos testes de Ácido Lático normalmente efetuados durante os treinamentos específicos que buscavam pela tolerância desse resultante metabólico. Durante as sessões de treinamentos que visavam essas capacidades a irritação da equipe como um todo ficou evidente. A força despendida nessas ocasiões, promove forte desconforto como: dores e acentuado estresse resultante. Nessas sessões especiais de treinamentos, efetuadas em um período específico do programa de preparação, foi possivel observar a determinação e a clareza dos objetivos esportivos. A nadadora estudada demonstrou um padrão normal e sempre com bons desempenhos, dentro das características apresentadas pelo grupo como um todo. Os testes de Ácido Lático objetivam demonstrar a capacidade de acúmulo, recuperação e remoção desse substrato sangüineo. Dessa forma pode-se aferir as capacidades físicas dos nadadores e as possiveis correções no programa de treinamento (MAGLISCHO, 1993, 2003; NAVARRO et al., 1990).

O QUADRO 4 demonstra alguns resultados de testes de ácido lático efetuados pela nadadora desse estudo. 
QUADRO 4 - Exemplos de resultados de testes de lactacidemia das temporadas 2001, 2002 e 2003 durante os treinamentos

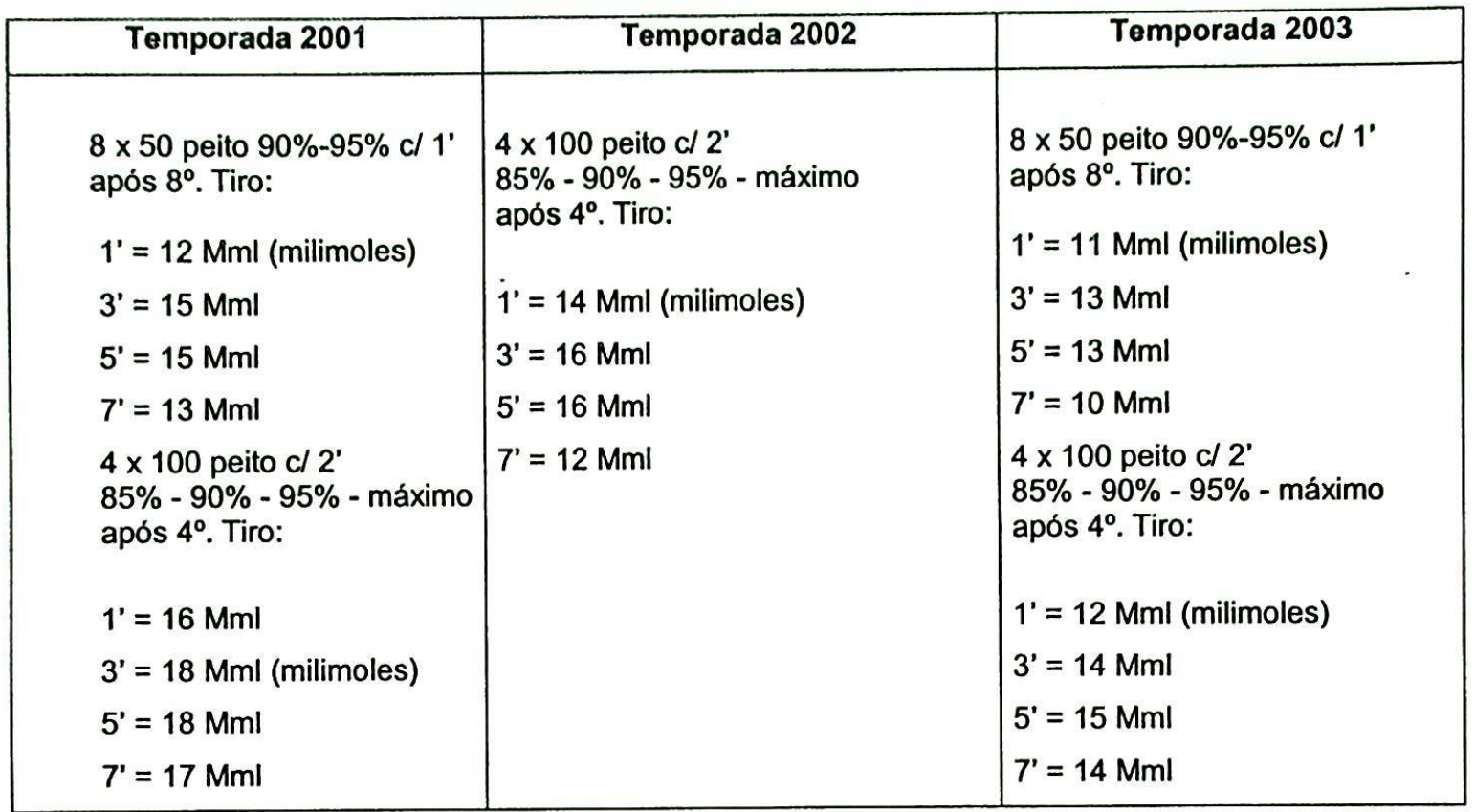

Fonte: Comissão Técnica

As coletas capilares de sangue no dedo indicador dos nadadores são efetuados seguindo um padrão de aferição após a última execução de tiros do protocolo utilizado para o testes aos 1', 3', 5'e 7' minutos.

\subsection{Entrevistas}

\subsubsection{Entrevistas iniciais}

Nas entrevistas iniciais, em um total de duas, de estrutura aberta, procurou-se observar qual a identidade do sujeito com relação à natação competitiva, bem como as primeiras narrativas referentes à sua história esportiva e aos seus projetos futuros.

As entrevistas iniciais ocorreram no início da temporada esportiva do ano de 2002. Nesses encontros, realizados no mês de fevereiro, foi firmado um contrato verbal, onde pesquisador e atleta acordaram suas intenções com referência à pesquisa e às formas de observação e atendimentos psicológicos esportivos, dirimindo-se todas as dúvidas com relação às intenções propostas. 


\subsubsection{Entrevistas psicológicas e identificação dos conflitos de objetivos esportivos}

Nas falas, foram observados os sentidos mais significativos no contexto global das vivências relatas, sendo selecionadas, a posteriori, situações que permitiram aproximação à questão central da investigação referente aos conflitos de objetivos esportivos que pudessem interferir negativamente nos resultados esportivos.

Os resultados esportivos obtidos no período compreendido entre 2000 e 2002 ocuparam significativamente as entrevistas, identificados na FIGURA 2 como período crítico.

As entrevistas preliminares ao processo interventivo foram iniciadas a partir de um resultado técnico considerado pela atleta muito aquém dos objetivos propostos para a ocasião. Mesmo cumprindo o programa integralmente, a nadadora obteve o tempo de 1'21"93, identificado na FIGURA 2 como a 14a . participação. Esse resultado foi considerado incompreensível pela CT como muito aquém da capacidade de execução da atleta. Esse resultado desencadeou um conflito tanto de ordem pessoal como de relacionamento com os treinadores. Essa situação de conflito possibilitou a presença do psicólogo pesquisador de uma forma mais próxima junto à nadadora e aos treinadores.

\subsubsection{Análise e interpretação dos discursos}

As entrevistas foram organizadas com um roteiro tópico predefinido e de seqüência flexivel, com o objetivo de possibilitar os estudos temáticos e comparativos dos depoimentos da atleta.

As entrevistas gravadas e, posteriormente, transcritas tiveram seus conteúdos categorizados, formando o conjunto de sentidos significativos referentes à questão investigada, possibilitando, assim, conjuntamente com a nadadora uma reflexão sobre os fatos vividos à luz da compreensão tanto do pesquisador como da entrevistada.

GOMES (1998, p.33) refere-se a esse movimento dialético como: 
"o ato perceptivo que vai ao encontro do objetivo não é uma simples apropriação subjetiva do objeto. Trata-se de um ato reflexivo capaz de combinar um sujeito que percebe com um objeto que está sendo percebido".

No QUADRO 5 são demonstrados dados relevantes contidos nas entrevistas iniciais. As falas mais significativas do sujeito foram agrupadas em categorias, permitindo, posteriormente, uma análise preliminar nas relações e clareza do sujeito com referência aos Objetivos Esportivos e à prática competitiva na modalidade, naqueles momentos.

QUADRO 5 - Dados significativos das primeiras entrevistas diagnósticas psicológicas

\begin{tabular}{|c|c|}
\hline Falas significativas & Falas, sentidos e categorias \\
\hline $\begin{array}{l}\text { 1. Não sei o que acontece! Venho treinando, } \\
\text { treinando e não consigo repetir os meus } \\
\text { melhores tempos; } \\
\text { 2. Isso me desanima, não sei o que } \\
\text { acontece. } \\
\text { 3. É difícil falar, não consigo. } \\
\text { 4. Ás vezes, no bloco de partida, me dá um } \\
\text { branco. } \\
\text { 5. Treino para repetir os meus melhores } \\
\text { resultados. } \\
\text { 6. Não me lembro das provas depois que eu } \\
\text { acabo de competir. } \\
\text { 7. É tudo meio automático. } \\
\text { 8. Não sinto se estou fazendo força. } \\
\text { 9. Logo depois que acabo de nadar, me } \\
\text { recupero facilmente (do cansaço). } \\
\text { 10. Me sinto triste. } \\
\text { 11. É muito bom estar em evidência. } \\
\text { 12. Tinha toda a atenção do técnico. } \\
\text { 13. Foi muito bom ter ganho aqueles títulos } \\
\text { em } 2000 \text {. } \\
\text { 14. Quero repetir os meus resultados quando } \\
\text { estava no auge. } \\
\text { 15. O pior momento é quando estou no banco } \\
\text { de balizamento, eu me sentia cansada. } \\
\text { 16. Não é muito bom ver as adversárias se } \\
\text { aproximando e batendo os meus recordes } \\
\text { 17. Agora não consigo chegar perto das } \\
\text { adversárias que eu vencia. } \\
\text { 18. Durante o aquecimento da competição eu } \\
\text { me sinto bem, mas na hora de nadar não } \\
\text { sei o que acontece. }\end{array}$ & $\begin{array}{l}\text { Liberdade da fala e da escuta } \\
\text { Nas primeiras entrevistas procurou-se motivar a } \\
\text { atleta para que ele falasse livremente sobre } \\
\text { suas vivências ao longo dos três últimos anos, } \\
\text { onde estão compreendidas as temporadas } \\
\text { esportivas que mais significaram para o } \\
\text { indivíduo. } \\
1 \text { - A projeção para o passado } \\
\text { As frases } 1,5,13,14,20,21,24 \text { e } 31 \\
\text { demonstram uma tendência de retorno para } \\
\text { momentos passados, realizações e conquistas } \\
\text { referentes a um momento muito especial da } \\
\text { atleta. } \\
2 \text { - A ansiedade } \\
\text { As frases } 4,8,15,18,22 \text { e } 23 \text { dão indícios do } \\
\text { estado de ansiedade pré-competitiva tendo em } \\
\text { vista a nadadora estar voltada para os objetivos } \\
\text { de resultado e não de execução. } \\
3 \text { - O automatismo } \\
\text { As frases } 6,7,8 \text { e podem ser relacionadas } \\
\text { com os estados de ansiedade pré-competitiva, } \\
\text { levando a nadadora a executar suas provas de } \\
\text { forma automática. Esse automatismo pode estar } \\
\text { relacionado com a mesma postura competitiva, } \\
\text { fazendo com que os resultados (tempos) } \\
\text { estejam muito próximos ou mesmo sendo } \\
\text { repetidos. } \\
4-\text { Frustração e auto-estima } \\
\text { As frases } 10,16,17,19,28,32 \text { e } 33 \text { dão indicios } \\
\text { do estado de frustração e nivel de auto-estima } \\
\text { da nadadora, demonstrando inclusive o quanto } \\
\text { ela está tentando retornar às conquistas } \\
\text { anteriores e a dificuldade em lidar com essa } \\
\text { impossibilidade. }\end{array}$ \\
\hline
\end{tabular}


QUADRO.5 - Dados significativos das primeiras entrevistas diagnósticas psicológicas. (continuação)

\begin{tabular}{|c|c|}
\hline Falas significativas & Falas, sentidos e categorias \\
\hline $\begin{array}{l}\text { 19. Isso me dá raiva. } \\
\text { 20. Só me preocupo com o tempo. } \\
\text { 21. Treinei muito bem, eu estava bem } \\
\text { treinada. } \\
\text { 22. Quando eu vi o tempo das meninas... } \\
\text { 23. Não consegui dormir bem antes da } \\
\text { competição. } \\
\text { 24. Eu quero voltar a fazer os mesmos } \\
\text { resultados que eu fiz naquela competição. } \\
\text { 25. Na hora da competição é a cabeça que } \\
\text { não vai. } \\
\text { 26. Nos treinos eu me sinto mito bem. } \\
\text { 27. Acho que nunca treinei tanto como desta } \\
\text { vez. } \\
\text { 28. Chorei bastante. } \\
\text { 29. Desta vez acho que foi a pior de todas. } \\
\text { 30. Nunca me senti tão mal como agora. } \\
\text { 31. Eu sei que estou mais forte e nadando } \\
\text { melhor agora, por isso não dá para } \\
\text { entender. } \\
\text { 32. Tenho me sentido triste esse tempo todo. } \\
\text { 33. Faço de conta, finjo que não percebo. }\end{array}$ & $\begin{array}{l}5 \text { - Aspectos psicossomáticos } \\
\text { As frases } 15 \text { e } 30 \text { indicam para as questões } \\
\text { somáticas referentes aos niveis de ansiedade } \\
\text { pré-competitiva elevados. Esse estado pode } \\
\text { interferir na sensibilidade do nadador com } \\
\text { referências ao meio liquido e aos aspectos } \\
\text { técnicos da execução dos movimentos dos } \\
\text { nados, principalmente nas fazes sub-aquáticas } \\
\text { das braçadas (varreduras). } \\
6 \text { - Conscientização e clareza } \\
\text { As frases } 11,12,25,26,27 \text { e } 29 \text { apontam para } \\
\text { uma compreensão parcial da nadadora, } \\
\text { referente as suas dúvidas em relação aos seus } \\
\text { objetivos } \\
7 \text { - Negação e conflitos } \\
\text { As frases } 2 \text {, } 3,33 \text { e } 34 \text { apontam para as } \\
\text { questões relacionadas aos estados de dúvidas, } \\
\text { negação e conflitos, o que pode implicar a busca } \\
\text { de objetivos irreais, voltados para o sucesso e } \\
\text { não para a execução das tarefas técnicas } \\
\text { esportivas, necessárias nos treinamentos e } \\
\text { competições. }\end{array}$ \\
\hline
\end{tabular}

Os dados, apresentados de forma resumida no QUADRO 5, mostram algumas afirmações significativas que evidenciam os aspectos psicológicos da nadadora com relação à participação de número 9 na FIGURA 2. Naquela ocasião, ela obteve expressivo resultado técnico em termos de tempo (1'15"75) e colocação ( $2^{\circ}$ lugar), medalha de prata em um importante torneio de âmbito internacional.

Essa competição, que projetou a nadadora no seu contexto social (familia, equipe esportiva, cidade, colégio e ranking nacional, mídia esportiva, patrocinadores), marcou-a, emocionalmente, a ponto de impedi-la na sua atuação plena em eventos posteriores, mesmo estando melhor preparada.

No QUADRO 6, pode-se observar alguns dos sentidos dado pela nadadora com relação ao período crítico vivenciado na Fase $\mathrm{C}$ do período préinterventivo. 
QUADRO 6- Dados significativos das entrevistas diagnósticas psicológicas referentes à Fase C que evidenciam conflitos de objetivos e de identidade esportiva

\begin{tabular}{|c|c|}
\hline Falas si & Falas, sentidos e categorias \\
\hline $\begin{array}{l}\text { 01. as pessoas não entendem como é duro } \\
\text { 02. os treinadores já não gostam mais de mim } \\
\text { 03. sinto um aperto no peito que não sei explicar } \\
\text { 04. na hora me falta força } \\
\text { 05. numa competição melhoro um pouco } \\
\text { 06. na outra é um lixo } \\
\text { 07. estou insegura } \\
\text { 08. será que as adversárias percebem } \\
\text { 09. tenho medo } \\
\text { 10.. e os meus patrocinadores } \\
\text { 11. o tempo foi uma merda } \\
\text { 12. que ódio } \\
\text { 13. um e vinte e um é foda } \\
\text { 14. o olhar dos outros me irrita } \\
\text { 15. a risadinha eu não suporto mais } \\
\text { 16. os meus pais } \\
\text { 17. eu não sei } \\
\text { 18. tento mais não consigo } \\
\text { 19. me sinto fracassada } \\
\text { 20. já não estou ligando } \\
\text { 21. no treino é mais legal } \\
\text { 22. consigo treinar bem } \\
\text { 23. chega na hora } \\
\text { 24. não sinto o meu corpo quando compito } \\
\text { 25. as vezes nem parece que tem água } \\
\text { 26. estou sofrendo } \\
\text { 27. me ajuda } \\
\text { 28. ninguém entende } \\
\text { 29. a prova é uma eternidade } \\
\text { 30.é sempre a mesma coisa } \\
\text { 31. parece que estou patinando no mesmo lugar } \\
\text { 32. se desse para voltar } \\
\text { 33. não percebia essas coisas } \\
\text { 34. como não dá para voltar } \\
\text { 35. me dá um tempo } \\
\text { 36. você está me irritando também } \\
\text { 37. eu quero ser o que eu era e pronto } \\
\text { 38. nado, nado, nado e não nado } \\
\text { 39. tristeza } \\
\text { 40. estou infeliz } \\
\text { 41. não entendo o que acontece } \\
\text { 42. sempre dou uma travada } \\
\text { 43. antes não acontecia } \\
\text { 44. é branco total } \\
\text { 45. tremedeira }\end{array}$ & 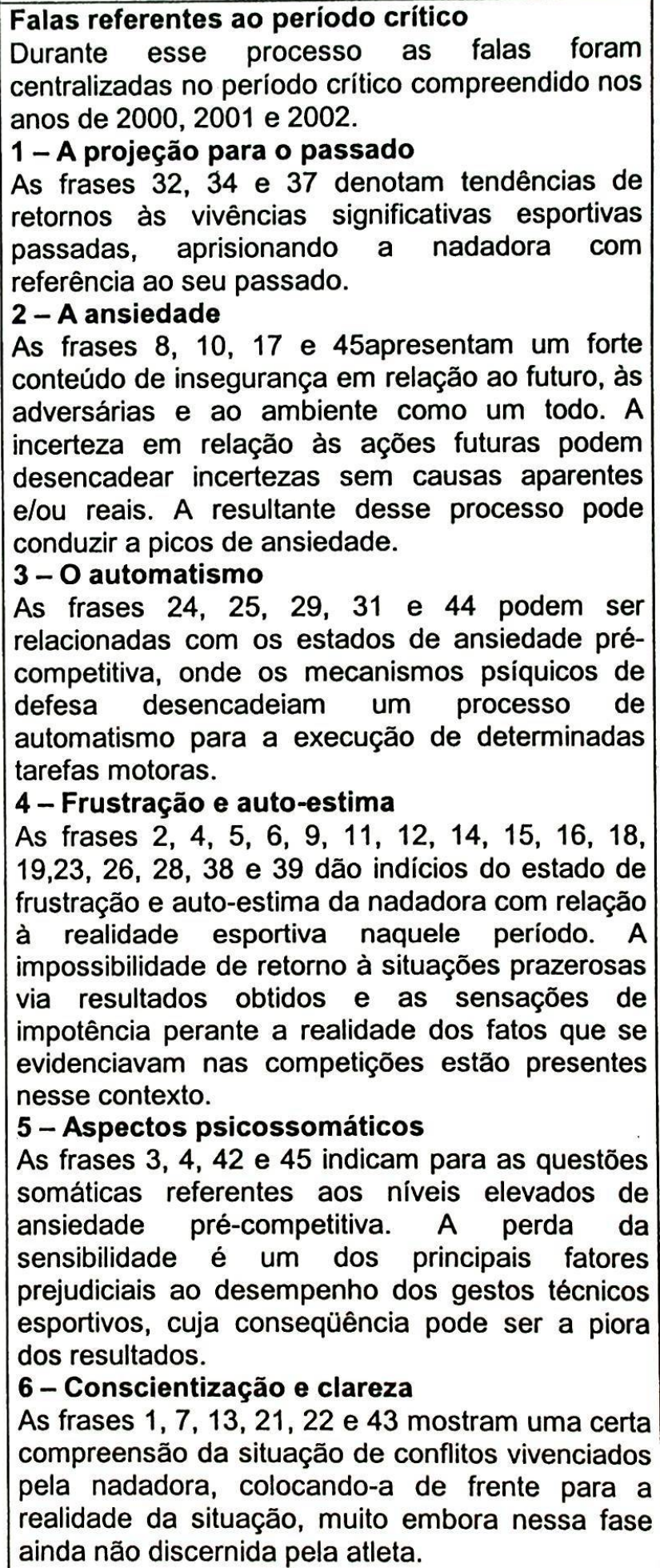 \\
\hline
\end{tabular}


QUADRO 6- Dados significativos das entrevistas diagnósticas psicológicas referentes à Fase C que evidenciam conflitos de objetivos e de identidade esportiva (continuação)

\begin{tabular}{|l|l|}
\hline Falas significativas & \multicolumn{1}{|c|}{ Falas, sentidos e categorias } \\
\hline & $\begin{array}{l}\text { 7- Negação e conflitos } \\
\text { As frases 20,27, 28,30,33, 35, 36, 40 e 41 } \\
\text { apontam para as situaçōes relacionadas aos } \\
\text { conflitos angustiantes vivenciados pela nadadora, } \\
\text { evidenciando a resistência, motivada pela falta de } \\
\text { estrutura psicológica, naquela ocasião, para lidar } \\
\text { com as questões do conflito. } \\
8-\text { Situação depressiva } \\
\text { As frases 27 e 39 demonstram o estado } \\
\text { depressivo da atleta numa determinada fase } \\
\text { competitiva. Nesse periodo a nadadora } \\
\text { apresentou uma bipolaridade no humor, com } \\
\text { alguns picos depressivos. Não foi necessário } \\
\text { entretanto o seu encaminhamento ao clínico } \\
\text { médico especializado, tendo em vista a mesma } \\
\text { não ter apresentado quadro que necessitasse tais } \\
\text { procedimentos, conforme clínico médico geral } \\
\text { naquele momento. }\end{array}$ \\
\hline
\end{tabular}

Essas frases foram retiradas de todo um contexto histórico de vida da nadadora. Referem-se, entretanto, somente aos aspectos pertinentes à prática da natação. Dentro dessa prática, várias nuanças permitem leituras interpretativas no campo da psicologia nas suas variáveis formas interpretativas da psique humana.

Uma vez definido o objeto investigativo - um estudo de caso de conflitos de objetivos esportivos - ele surge naturalmente dentro das muitas falas do sujeito. Aspectos pontuais que compõem e contrapõem as histórias dos indivíduos, fazem parte do contesto pleno das existências humanas. Os fatos podem ser observados isoladamente, como o que ocorre nesse estudo, mas não existiriam isoladamente. A medida em que fatos focados vão surgindo, situações extra-tema surgem naturalmente. Essas situações podem ser relevantes para a apreensão e entendimento dos fatos intencionados. Todas as situações faladas devem ser observadas atentamente por quem interpreta. Como retalhos, vão sendo costurados e tomando formato. A princípio nada é muito claro. Ocorre, entretanto, um desvelar de significados ritmados. Essa cadência é ditada por quem detém a fala. Nesse 
estudo, a nadadora. Esse encontro de quem fala com quem escuta, livre de préconceituações que possam estar levando às conclusões precipitadas e interpretações inconsistentes e, por conseguinte, errôneas, marcam o encontro autêntico. Nesse envolvimento espera-se que surja a compreensão dos sentidos dos fatos vividos. Tanto por parte de quem fala como por parte de quem escuta. Ambos, no caso, atleta e psicólogo, vão trilhando por um caminho de sentidos e significados. É uma troca para a construção. O objetivo prioritário é a compreensão da história por quem a narra, numa primeira instância. Por vezes o psicólogo observa fatos com clareza que não atingem, no momento, o narrador. Em outras situações, o interlocutor não atinge também a clareza dos fatos. A nebulosidade atinge a ambos. É preciso que a ansiedade do psicólogo seja observada pelo próprio, para que não salte no futuro do indivíduo. As narrações, composta de sentidos e emoções advindas das vivências que marcam e constroem as existências, devem fluir livre $e$ com naturalidade. É preciso estar atento na escuta, pois fatos que ora surgem como claros, vão, em outros momentos, parecer confusos. O livre transitar, construído no ir-e-vir dos fatos, na medida em que o narrador suporta emocionalmente estar de frente para esses mesmos fatos, vai evoluindo à clareza do entendimento, da compreensão.

A esperada mudança de comportamento poderá então, instaurar-se no momento do desvelado. Novos sentidos, novos significados, novos fatos passam a constituir então, a vida do sujeito. É o continuar na existência. As vivências vão se sucedendo, assim como a vida. No caso dos atletas, a prática esportiva toma um sentido amplo na construção da existência. Por um período da vida, os atletas assumem papeis que são vivenciados intensamente mediante suas performances. A busca permanente pela compleição, via satisfação das necessidades psíquicas, são extravasadas mediante as tentativas de conquistas de novos resultados esportivos. Esse talvez seja um dos principais motivos do aprisionamento emocional nos grandes momentos prazerosos de situações vivenciadas. $O$ atleta vive esses curtos momentos nos grandes eventos esportivos. Ali ele consegue, mediante desempenho performáticos, ascender à posições de destaque grupal. Idealizado, configura-se como objeto de desejo, o ser campeão. Essa situação é renovada a cada evento. Da mesma forma que as performances podem ser melhoradas, criando o status quo 
tanto social como emocional, podem ser pioradas, ameaçando essas mesmas configurações de ordem psicológicas. Os papeis sociais são impregnados de significados emocionais. A competição pode tanto tomar uma configuração motivadora como ameaçadora, dependendo de como o atleta se posiciona frente a ela. Ou ele parte para o confronto, assumindo atitude competitiva esportiva ofensiva ou ele se defende escapando. A apatia competitiva demonstrada por vezes no campo esportivo, expõem a atitude competitiva esportiva defensiva. Essa esquematização pode ser observada na FIGURA 1.

Outra possibilidade é a tentativa psicológica de permanência ou continuidade na situação que gera prazer. É preciso aprender a se despedir, sem abandonar contudo, os momentos significativos para a continuidade $e$ reordenamento do objetivos. O esporte vive de apelo presente e futuro e não de apelo passado. $O$ evento findo passa a compor os fatos vivenciados. $O$ foco de execução deve permanecer no tempo presente e futuro.

\subsubsection{Intervenções psicológicas referentes às questões desveladas e a Fase D do período pós-interventivo}

A entrevista psicológica caracteriza-se "per se" como processo interventivo, no momento em que o sujeito é conduzido tecnicamente às questões referentes ao seu histórico como um todo.

$\mathrm{O}$ procedimento intensificou-se a partir do momento em que a atleta observou a necessidade de aprofundar-se nas questões que iam surgindo à medida que as entrevistas se sucediam. O vínculo foi se estabelecendo, com o cuidado necessário para que a atleta não visse o pesquisador como referência única, tornando-se dependente do processo.

As questões que extrapolaram o ambiente esportivo foram suprimidas propositalmente nessa pesquisa, pois a mesmo objetiva investigação nas questões referentes aos conflitos de Objetivos Esportivos, cujas vivências passadas podem aprisionar o atleta, impedindo-o, dessa forma, de projeções futuras para o seu desempenho. 
As entrevistas foram se sucedendo dentro do ritmo ditado pela nadadora. Embora a questão central da pesquisa - conflitos de objetivos referentes às situações vivenciadas - estivesse evidente para o pesquisador, a atuação ocorreu sempre atrelada ao entendimento e ritmo da nadadora. A atleta foi, em todo o percurso, o centro do processo, cujos cuidados objetivaram impedir que a ansiedade do pesquisador promovesse saltos atemporais.

O fenômeno desvelado é o momento rico de todo o processo interventivo psicológico. A mudança de comportamento ocorre progressivamente dentro do processo de entendimento do indivíduo, sendo ele, portanto, a razão principal da intervenção. $O$ comportamento não se refere somente às questões pontuais, mas a vida. Os episódios não ocorrem isoladamente quando se refere às questões psicológicas. Eles interferem no individuo como um todo. $O$ ser atleta insere-se no ser indivíduo. Isso leva o processo interventivo, quando se trata de conflitos, às questões existenciais do estar no mundo.

Na FIGURA 13 são demonstras as participações de números 1819 e 20 com resultados melhorados em relação a todas as performances anteriores. 


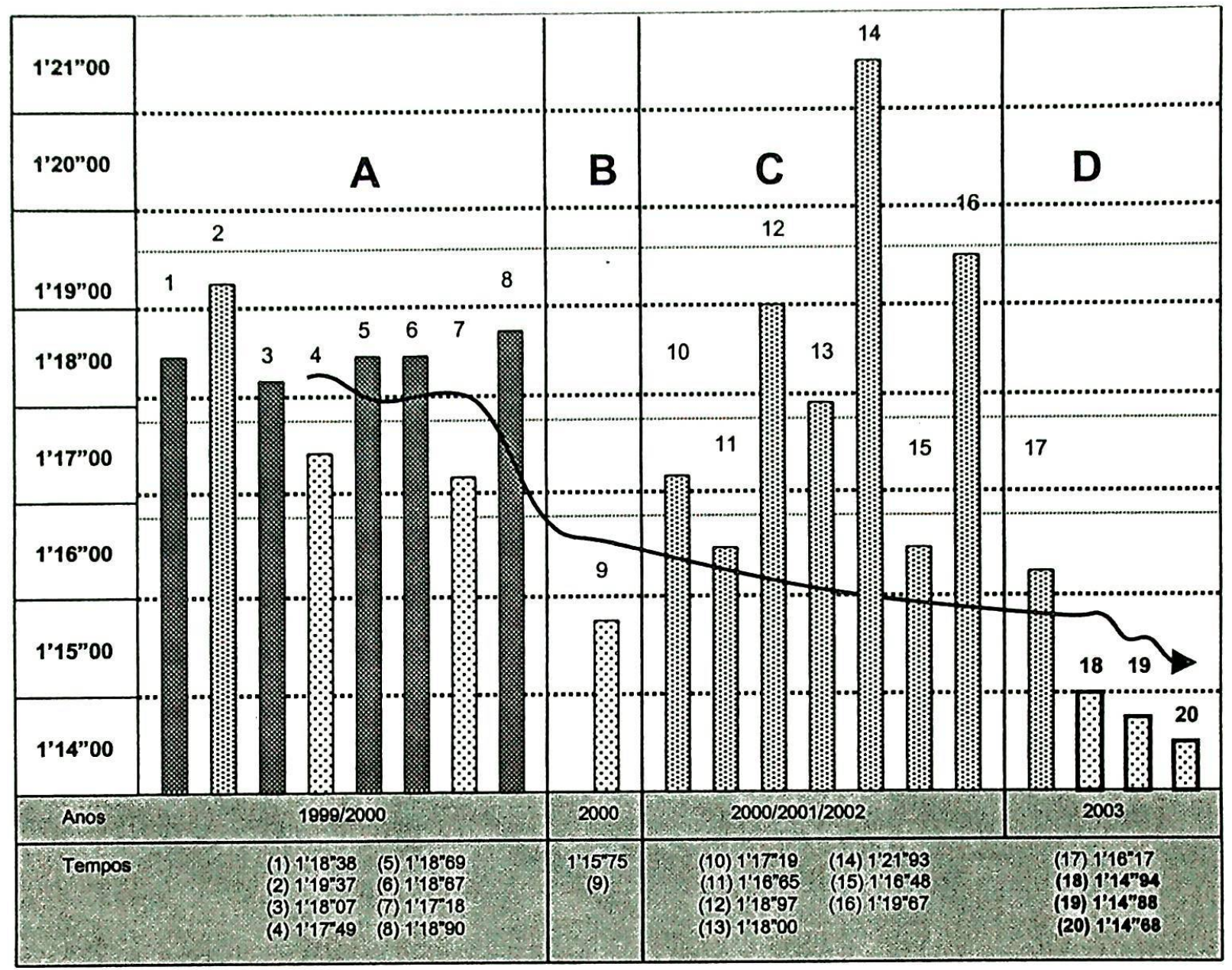

Performance Estabilizada

FIGURA 13 - Comparativo qualitativo das Fases A, B, C pré-interventiva e da Fase D pós-interventiva

Na FIGURA 13 pode ser observado que nas atuações de números 18,19 e 20 ocorreram melhora qualitativa em relação à participação de número 09 ocorrida duas temporadas e meia anteriores.

O processo de intervenção psicológica teve o seu início a partir da $16^{a}$ atuação quando a nadadora obteve o tempo de 1'19"67 (um minuto e dezenove segundos e sessenta e sete centésimos de segundo), no final do ano de 2002.

Ao final dessa temporada, após esse resultado, a nadadora demonstrava abatimento e apatia. Desmotivada, expressava não entender o que vinha ocorrendo 
nas competições, pois o seu treinamento era executado dentro dos padrões esperados pelo treinador. Alguns exemplos de falas, já categorizadas, referentes à fase C, podendo ser observadas no QUADRO 6.

\section{A Fase D}

$\mathrm{Na}$ Fase $\mathrm{D}$ o processo interventivo teve como objetivo principal auxiliar o entendimento das vivências. Como conseqüência de um novo olhar esperava-se, como parte desse estudo, pelo re-significado dos objetivos esportivos e as atitudes competitivas por parte da atleta. A variável psicológica estaria, dessa forma, sendo trabalhado, a exemplos das demais integrantes do programa de treinamento.

A TABELA 11 demonstra os ganhos qualitativos da Fase $D$ em relação ao melhor tempo da Fase B.

TABELA 11 - Demonstrativo dos ganhos qualitativos dos resultados da Fase $D$ em relacão ao melhor tempo da Fase B

\begin{tabular}{|c|c|c|c|c|}
\hline Fase & No. & Tempo & $\mathrm{m} / \mathrm{s}$ & $\%$ \\
\hline B & $09^{\mathrm{a}}$. & $1^{\prime} 15^{\prime \prime} 75$ & $1.32,01$ & 100 \\
\hline D & $17^{\mathrm{a}} \cdot$ & $1^{\prime} 16^{\prime \prime} 17$ & $1.31,28$ & $>0.554$ \\
\hline D & $18^{\mathrm{a}}$. & $1^{\prime} 14^{\prime \prime} 94$ & $1.33,44$ & $<1.069$ \\
\hline D & $19^{\mathrm{a}}$. & $1^{\prime} 14^{\prime \prime} 88$ & $1.33,54$ & $<1.148$ \\
\hline D & $20^{\mathrm{a}}$. & $1^{\prime} 14^{\prime \prime} 68$ & $1.33,90$ & $<1.412$ \\
\hline
\end{tabular}

A FIGURA 14 mostra a melhora do desempenho na fase pós-interventiva.

\begin{tabular}{|c|c|c|c|c|}
\hline Ano 2003 & $17^{\circ}$ & 18. & $19^{\circ}$ & 20 . \\
\hline \multicolumn{5}{|l|}{ 1'16" 00} \\
\hline \multicolumn{5}{|l|}{1 15" 00} \\
\hline \multicolumn{5}{|l|}{ 1'14" 00} \\
\hline Tempos & $116^{\prime \prime 17}$ & 1'14"9 & $14^{\prime \prime} 8$ & $114 " 68$ \\
\hline
\end{tabular}

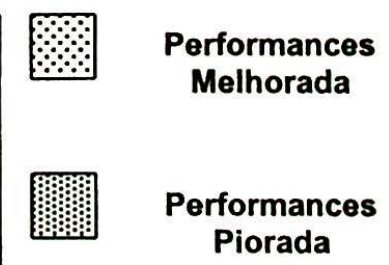

FIGURA 14 - Representacão das melhoras de desempenhos nas participacões da Fase $D$ de números $17,18,19$ e 20 
É importante salientar que o processo de intervenção psicológica esportiva ocorrida nesse estudo, não aconteceu isoladamente. A participação do treinador, com quem a nadadora tem um vínculo fortemente estruturado, no processo de acompanhamento e discussões técnicas, foram fundamentais. Durante os treinamentos e competições, os atletas de natação se acercam dessa figura, deixando claro a importância desse papel nas referências necessárias às atuações $e$ condutas técnicas dos nadadores. Por vezes, a figura do treinador surgiu nas falas da atleta quando nas entrevistas, o que evidenciou a importância desse profissional orientador junto aos jovens desportistas.

O conteúdo do QUADRO 7, refere-se à partição de número 18 quando a nadadora obteve o tempo de 1'14"94 e a primeira colocação num campeonato estadual no ano de 2003, aproximadamente dois anos e meio após obter o tempo de 1 '15"75.

\section{QUADRO 7- Exemplos de alguns dados significativos das entrevistas psicológicas referentes à Fase $D$ que evidenciam o processo de interacão e o resignificado dos conflitos de objetivos e reorganizacão da identidade esportiva.}

\begin{tabular}{|c|c|}
\hline Falas significativas & Falas, sentidos e categorias \\
\hline $\begin{array}{l}\text { 01. é uma loucura } \\
\text { 02. eu não sei como isso aconteceu } \\
\text { 03. eu não estava esperando } \\
\text { 04. eu fiquei meio assim... } \\
\text { 05. tanto que a gente conversou } \\
\text { 06. eu queria chegar e me sentir bem na prova } \\
\text { 07. sentir que eu estava dentro da competição } \\
\text { 08. ai eu cheguei lá na minha primeira prova } \\
\text { 09. os } 200 \text { medley não é o meu forte } \\
\text { 10. o tempo não foi lá essas coisas } \\
\text { 11. mas eu me senti mais na competição } \\
\text { 12. fazia um tempo que eu não me sentia dessa } \\
\text { forma legal } \\
\text { 13. Mas eu sabia que estava lá novamente } \\
\text { 14. olha eu aí gente } \\
\text { 15. mais competitiva } \\
\text { 16. confiante } \\
\text { 17. mas mesmo assim fiquei meio retraída } \\
\text { 18. acho que fazia uns dois anos que eu não } \\
\text { nadava } \\
\text { 19. aí eu fui nadar os } 100 \text { peito.. } \\
\text { 20. na eliminatória eu no nadei muito bem não } \\
\text { 21. nadei forte mas fiz } 1 \text { '21" } \\
\text { 22. classifiquei com o } 6^{\circ} \text {. tempo }\end{array}$ & $\begin{array}{l}\text { Falas referentes ao período competitivo de } \\
\text { intervenção da Fase D } \\
1 \text { - A projeção para o passado } \\
2 \text { - A ansiedade } \\
\text { As frases } 6,17,24,27,28 \text { e } 29 \text { dão indícios dos } \\
\text { niveis de ansiedade pré-competitiva dentro do } \\
\text { processo de transição de uma fase para a outra. } \\
\text { Os níveis de ansiedade, quando nos patamares } \\
\text { ideais sem fugir ao controle do atleta, pode } \\
\text { beneficiar o competidor. Nas primeiras } \\
\text { competições da fase D, a atleta alternou os niveis } \\
\text { de ansiedade, como era esperado nesse estudo, } \\
\text { tendo em vista o longo periodo da fase C. } \\
3-\text { O automatismo } \\
\text { As frases } 21,23 \text { e } 26 \text { demonstram niveis de } \\
\text { ansiedade pré-competitiva intervenientes na } \\
\text { conscientização da execução. } \\
\text { O automatismo demonstra que o atleta apresenta } \\
\text { um certo nível de dúvida e não clareza quanto a } \\
\text { sua participação. Se esperava, nessa fase de } \\
\text { reconstrução de referências, atitudes como as } \\
\text { descritas. }\end{array}$ \\
\hline
\end{tabular}


QUADRO 7- Exemplos de alguns dados significativos das entrevistas psicológicas referentes à Fase D que evidenciam o processo de interacão e o resignificado dos conflitos de objetivos e reorganizacão da identidade esportiva.

\begin{tabular}{|c|c|}
\hline Falas significativas & Falas, sentidos e categorias \\
\hline $\begin{array}{l}\text { 23. aí na final eu não sei o que aconteceu } \\
\text { 24. eu não estava muito concentrada } \\
\text { 25. sabia o que eu tinha que fazer } \\
\text { 26. eu já tinha pensado } \\
\text { 27. mas ao mesmo tempo atrás da baliza eu } \\
\text { estava desconcentrada } \\
\text { 28. olhando para o pessoal na arquibancada } \\
\text { 29. era final e eu estava dispersa } \\
\text { 30. ai eu caí na água } \\
\text { 31. eu sei que eu dei uma saída boa e uma } \\
\text { filipina melhor ainda } \\
\text { 32. eu me lembro direitinho de tudo } \\
\text { 33. mas até aí não quer dizer nada } \\
\text { 34. saí pensando em passar forte nos } 50 \text { metros } \\
\text { 35. e continuei nadando } \\
\text { 36. foi a prova que eu me senti mais competitiva } \\
\text { 37. fazia tempo né } \\
\text { 38. eu já passei na frete das meninas } \\
\text { 39. eu sabia um pouco que eu estava na frente } \\
\text { 40. dava para ouvir um pouco a galera na geral } \\
\text { 41. mas ao mesmo tempo eu não achava que } \\
\text { estava na frente } \\
\text { 42. eu achava que estava buscando na segunda } \\
\text { volta } \\
\text { 43. eu estava sentindo a minha prova } \\
\text { 44. não dava para perceber direito o que estava } \\
\text { acontecendo do lado } \\
\text { 45. eu só via a parede do outro lado chegando } \\
\text { 46. só prestava atenção na prova } \\
\text { 47. quando cheguei ai que eu vi } \\
\text { 48. eu não estava acreditando muito } \\
\text { 49. tanto tempo que isso não acontecia } \\
\text { 50. chorei }\end{array}$ & $\begin{array}{l}\text { 4-A frustração e auto-estima } \\
\text { As frases } 10,18,37 \text { e } 49 \text { demonstram o processo } \\
\text { de realidade transcorrendo, quando a nadadora } \\
\text { observa o periodo de estagnação sem a nitida } \\
\text { compreensão, então, dos motivos que a } \\
\text { imobilizavam. } \\
5 \text { - Aspectos psicossomáticos } \\
\text { A frase } 43 \text { demonstra as sensações positivas } \\
\text { corporais dos competidores. A presença na prova } \\
\text { deve ser plena. Os aspectos físicos e psiquicos se } \\
\text { completam, dando a sensação de controle para o } \\
\text { atleta, das suas funções e execuções. } \\
6 \text { - Conscientização e clareza } \\
\text { As frases } 1,5,7,8,9,11,13,15,16,19,20,25, \\
30,31,32,34,35,36,38,39,40,43,45,46 \text { e } 47 \\
\text { apontam para uma compreensão do processo } \\
\text { como um todo. Ele é lento e deve ser conduzido } \\
\text { no ritmo de entendimento do sujeito para que se } \\
\text { efetive de forma consistente. } \\
7 \text { - Negação e conflitos } \\
\text { As frases } 2,4 \text { e } 41 \text { demonstram dúvidas e } \\
\text { insegurança. A retomada da confiança competitiva } \\
\text { demanda também retorno gradual. A fragilidade é } \\
\text { esperada nesse periodo de recondução. } \\
8-\text { Situação depressiva } \\
\text { Não houve nenhuma manifestação relacionada a } \\
\text { esta categoria } \\
9-\text { Euforia } \\
\text { As frases } 3,12,14 \text { e } 50 \text { mostram componentes de } \\
\text { euforia não somente pelos resultados em } \\
\text { relação ao tempo, mas, no caso, pela forma de } \\
\text { apresentação no ambiente competitivo como um } \\
\text { todo. O estar na competição de forma plena. } \\
10-\text { Dúvida e insegurança } \\
\text { As frases } 42,44 \text { e } 48 \text { se alternam com as } \\
\text { categorias anteriores. É esperado que o atleta em } \\
\text { fase de reestrutura alterne pensamentos com } \\
\text { componentes positivos e negativos. A medida em } \\
\text { que sua segurança e seus propósitos vão se } \\
\text { solidificando e os objetivos voltando para as } \\
\text { execuções, espera-se que os pensamentos } \\
\text { positivos assumam maiores proporções. }\end{array}$ \\
\hline
\end{tabular}


O QUADRO 8 contém algumas falas referentes à percepção da nadadora quanto a sua participação de número 19 , na prova dos 100 metros nado peito, quando registrou a marca de 1'14"88 num campeonato nacional, obtendo a primeira colocação.

QUADRO 8- Exemplos de alquns dados significativos das entrevistas psicológicas referentes à Fase D que evidenciam a compreensão dos fatos esportivos conflituosos vivenciados

\begin{tabular}{|c|c|}
\hline Falas significativas & Falas, sentidos e categorias \\
\hline $\begin{array}{l}\text { 01. não estou acreditando } \\
\text { 02. pelo jeito que eu nadei as outras competições } \\
\text { esse tempo todo } \\
\text { 03. acho que foi mais a confiança } \\
\text { 04. é isso, desta vez foi a confiança } \\
\text { 05. de acreditar na competição } \\
\text { 06. não pensei no resultado } \\
\text { 07. eu sei que eu podia nadar e até melhorar } \\
\text { 08. isso fez a diferença } \\
\text { 09. nesta eu entrei mais competitiva } \\
\text { 10. eu estava mais confiante } \\
\text { 11. mais determinada } \\
\text { 12. nas outras eu competia para não piorar o } \\
\text { tempo } \\
\text { 13. eu já ia pensando assim } \\
\text { 14. dava tudo errado } \\
\text { 15. a sensação era muito ruim } \\
\text { 16. foram anos } \\
\text { 17. sentia muito medo } \\
\text { 18. eu fui determinada em me sentir bem } \\
\text { nadando } \\
\text { 19. acho que desta vez eu cai na água como se } \\
\text { não tivesse as outras competições } \\
\text { 20. sem ficar pensando nas outras } \\
\text { 21. foi muito diferente } \\
\text { 22. eu fui pensando que ali sairia o melhor se eu } \\
\text { nadasse forte } \\
\text { 23. não fiquei naquela confusão } \\
\text { 24. deu certo } \\
\text { 25. era como se eu estivesse só nadando } \\
\text { 26. eu me senti mais leve para nadar } \\
\text { 27. parece que está mais fácil } \\
\text { 28. é muito diferente } \\
\text { 29. estou mais leve } \\
\text { 30. acho que estou entendendo melhor as coisas } \\
\text { 31. eu não via nada } \\
\text { 32. não sinto mais aquele aperto no peito } \\
\text { 33. estou feliz de novo com a natação }\end{array}$ & $\begin{array}{l}\text { Falas referentes ao período competitivo da } \\
\text { fase D } \\
\text { 1-A projeção para o passado } \\
\text { A frase } 20 \text { traz os conteúdos passados sem a } \\
\text { conotação de pesar, onde o trânsito da nadadora } \\
\text { surge com outro contesto. Sem pesar, sem } \\
\text { conotação de perda. } \\
2 \text { - A ansiedade } \\
\text { Não houve manifestação relacionada a esta } \\
\text { categoria } \\
3 \text {-O automatismo } \\
\text { A frase } 23 \text { que aparece também na categoria } \\
\text { conscientização e clareza, aqui denota os niveis } \\
\text { de ansiedade pré-competitiva que } \\
\text { acompanhavam a nadadora em competições } \\
\text { anteriores, notadamente na fase C quando a } \\
\text { mesma desencadeava um mecanismo de defesa } \\
\text { psicológico que a conduzia para o processo } \\
\text { autômato. } \\
4-\text { Frustração e auto-estima } \\
\text { As frases } 15,16,17 \text { e } 31 \text { dão indicios de } \\
\text { sensação de perda e pesar. A frase } 31 \text { foi } \\
\text { pronunciada demonstrando forte sentimento de } \\
\text { culpa pela não compreensão, naquelas ocasiões } \\
\text { do processo de imobilização motivado pelos } \\
\text { conflitos de objetivos esportivos. } \\
5-\text { Aspectos psicossomáticos } \\
\text { As frases } 26,29 \text { e } 32 \text { evidenciam um melhor } \\
\text { controle da situação pré-competitiva e } \\
\text { competitiva. As sensações corporais resultantes } \\
\text { do estresse competitivo demonstram estar sob um } \\
\text { melhor controle. A frase } 32 \text { denota o quanto de } \\
\text { angústia acompanhou, por um longo período, } \\
\text { compreendido por duas temporadas e meia, a } \\
\text { nadadora nos eventos competitivos. }\end{array}$ \\
\hline
\end{tabular}


QUADRO 8- Exemplos de alguns dados significativos das entrevistas psicológicas referentes à Fase D que evidenciam a compreensão dos fatos esportivos conflituosos vivenciados (continuação)

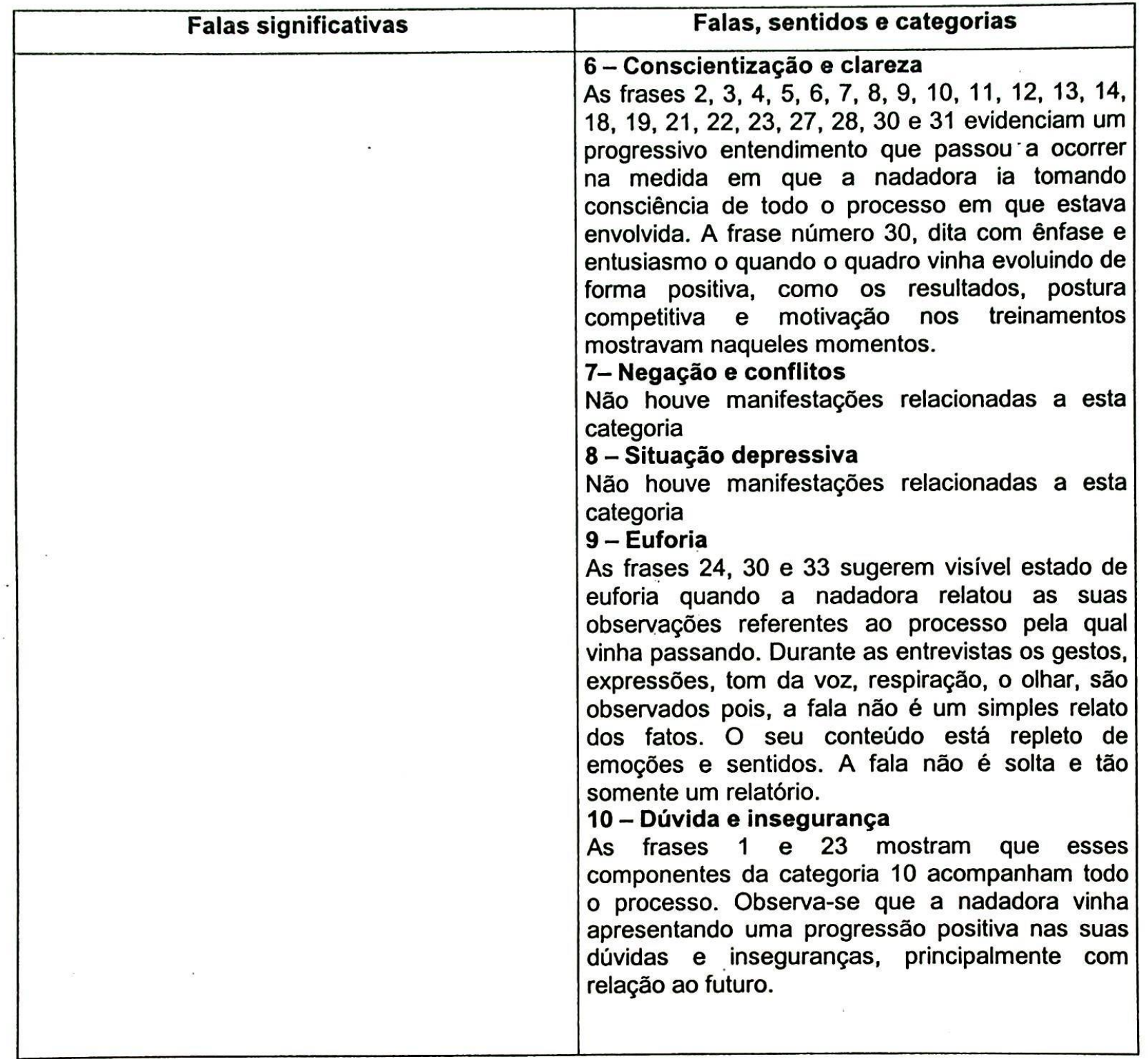

O QUADRO 9 contém algumas falas referentes à percepção da nadadora quanto a sua participação de número 20 , na prova dos 100 metros nado peito, quando registrou a marca de 1'14"68 num campeonato estadual, obtendo a primeira colocação. 
QUADRO 9 - Exemplos de dados significativos das entrevistas psicológicas referentes à Fase D que evidenciam a transicão compreensiva da nadadora

\begin{tabular}{|c|c|}
\hline Falas significativas & Falas, sentidos e categorias \\
\hline $\begin{array}{l}\text { 01. desde aquela bendita competição em } 2000 \\
\text { 02. eu vinha competindo com muita pressão } \\
\text { 03. era terrivel } \\
\text { 04. muita carga } \\
\text { 05. muita cobrança } \\
\text { 06. de todos } \\
\text { 07. minha também } \\
\text { 08. esse tempo todo } \\
\text { 09. só eu sei como foi esses anos } \\
\text { 10. agora que eu percebo } \\
\text { 11. foi muito duro } \\
\text { 12. não ia } \\
\text { 13. treinava, treinava e não ia } \\
\text { 14. o pior é que eu não percebia } \\
\text { 15. que merda } \\
\text { 16. desde } 1999 \text { só me senti bem em duas ou três } \\
\text { competições } \\
\text { 17. eu fingia que estava me sentindo bem } \\
\text { 18. as competições iam chegando e eu senti um } \\
\text { aperto no peito } \\
\text { 19. acho que ficava meio angustiada } \\
\text { 20. incomodava } \\
\text { 21. não tinha ânimo } \\
\text { 22. eu ia lá e já sabia o que eu ia sentir } \\
\text { 23. o que eu ia passar } \\
\text { 24. tudo de novo } \\
\text { 25. mesmo antes da competição eu já sabia } \\
\text { o que ia acontecer lá na hora } \\
\text { 26. eu não conseguia nadar } \\
\text { 27. no aquecimento as vezes estava legal } \\
\text { 28. na prova dava tudo errado } \\
\text { 29. fazia tudo sem sentir na prova } \\
\text { 30. saber que está treinada e não conseguir } \\
\text { 31. agora tem sido diferente } \\
\text { 32. eu sinto a água } \\
\text { 33. percebo tudo o que está acontecendo } \\
\text { 34. tenho melhor controle da prova } \\
\text { 35. no banco de espera me controlo melhor } \\
\text { 36. não dá o branco } \\
\text { 37. me incomodava saber que eu estava } \\
\text { preparada e não conseguia competir } \\
\text { 38. parto para cima das meninas } \\
\text { 39. me dáa raiva } \\
\text { 40. sinto que estou mais forte quando estou com } \\
\text { raiva }\end{array}$ & $\begin{array}{l}\text { Falas referentes ao período competitivo da } \\
\text { fase D } \\
\text { 1-A projeção para o passado } \\
\text { As frases } 1 \text { e } 16 \text { mostram certa mudança de } \\
\text { referência com relação à competição registrada } \\
\text { nesse trabalho como número } 9 \text {. A nadadora } \\
\text { passou a referir-se à competição, até então } \\
\text { referencial, com um certo nivel de desprezo. } \\
\text { Essas reações são esperadas tendo vista o } \\
\text { processo de reorganização dos objetivos } \\
\text { esportivos voltados para o alto rendimento. O } \\
\text { componente raiva ficou evidente. } \\
2 \text {-A ansiedade } \\
\text { As frases } 18 \text { e } 35 \text { evidenciam os niveis elevados } \\
\text { de ansiedade enfrentados pela nadadora nas } \\
\text { competições. } \\
3-0 \text { automatismo } \\
\text { Não houve manifestações relacionadas a esta } \\
\text { categoria } \\
4-\text { Frustração e auto-estima } \\
\text { As frases } 1,8,14,15,22,23,24,26,28,30 \text { e } 39 \\
\text { demonstram frustração e impotência quanto ao } \\
\text { controle da situação e do tempo de existência. } \\
5-\text { Aspectos psicossomáticos } \\
\text { As frases } 18 \text { e } 29 \text { evidenciam situações } \\
\text { incontroláveis que acompanhavam a nadadora } \\
\text { durante esse periodo conflitivo. Um aspecto } \\
\text { positivo dentro da seqüência de entrevistas } \\
\text { psicológicas foi a clareza e naturalidade que } \\
\text { essas questões eram abordadas. } \\
6 \text { - Conscientização e clareza } \\
\text { As frases } 2,3,5,6,7,14,32,33,34,38 \text { e } 40 \\
\text { dão claros indícios da retomada do controle pré- } \\
\text { competitivo e competitivo pela nadadora. As } \\
\text { frases } 34 \text { e } 38 \text { demonstram claras mudanças de } \\
\text { atitudes competitivas. } \\
7-\text { Negação e conflitos } \\
\text { As frases } 12,13,17 \text { e } 30 \text { apontam para situações } \\
\text { conflituosas. A citação } 17 \text { expõe claramente o } \\
\text { elevado nivel de conflito experienciado pela atleta. } \\
8-\text { Situação depressiva } \\
\text { As frases } 9,11,19,20 \text { e } 21 \text { demonstram a } \\
\text { tendência depressiva que se evidenciava no } \\
\text { processo. A frase } 21 \text { evidencia essa situação. }\end{array}$ \\
\hline
\end{tabular}


QUADRO 9 - Exemplos de dados significativos das entrevistas psicológicas referentes à Fase D que evidenciam a transicaão compreensiva da nadadora. (continuação)

\begin{tabular}{|l|l|}
\hline Falas significativas & \multicolumn{1}{|c|}{ Falas, sentidos e categorias } \\
\hline & $\begin{array}{l}9 \text { - Euforia } \\
\text { Não houve manifestação relacionadas a esta } \\
\text { categoria } \\
10 \text { - Dúvida e insegurança } \\
\text { As frases 25, 27 e 37 denotam as situações de } \\
\text { insegurança. Frases como a de número 37 } \\
\text { estiveram sempre presentes durante todo o } \\
\text { processo desse estudo. Isso evidencia o bloqueio } \\
\text { competitivo desenvolvido pela atleta. }\end{array}$ \\
\hline
\end{tabular}

\subsubsection{A apreensão e compreensão: o processo de interação}

No QUADRO 10 foram selecionadas algumas falas referentes à apreensão e compreensão da nadadora com relação a todo o processo conflitivo por ela vivenciado, em todo o periodo compreendido entre a 09a e $20^{\mathrm{a}}$. atuações competitivas. Esse período centralizou as atenções desse estudo, tendo em vista as alterações comportamentais apresentada pela nadadora tanto na fase préinterventiva como, principalmente, na fase pós-interventiva.

O entendimento por parte da atleta e mesmo pelo pesquisador, foi sendo construído ao longo desse processo. Em muitos momentos, várias questões foram refeitas, possibilitando uma ampliação do entendimento da questão da temporalidade e interinidade das performances esportivas e mesmo do ser campeão.

A construção dos sentidos não ocorreu linearmente. Idas e vindas nas vivências vão consolidando um grande painel de fatos que permitiram, então, uma grande figura com algum sentido. Aí talvez resida a interação e o encontro autêntico dos sujeitos que falam-e-ouvem numa só sintonia. A sintonia da compreensão.

O QUADRO 10 condensa falas retiradas de vários encontros que ocorreram ao longo da pesquisa. Elas representam vários momentos marcantes dessa caminhada de despedida e reordenamento. Despedir-se não significa abandonar e sim abrir espaço na possibilidade de ser. É a espiral em movimento ascendente. 


\section{QUADRO 10 - Exemplos de dados significativos das entrevistas psicológicas referentes à compreensão de todo o processo de intervencão}

\begin{tabular}{|l|}
\hline \multicolumn{1}{|c|}{ Falas significativas } \\
\hline 01. eu não sabia o que acontecia \\
02. o mais difícil é compreender que a gente tem \\
que esquecer o resultado da competição \\
03. partir para outro
\end{tabular}

04. acho que tem que partir para outro como se fosse a primeira

05. deve buscar outro objetivo

06 . eu vivia pensando naquele resultado

07. já era e eu não percebia

08. eu treinava e lembrava daquela situação

09. ela nunca voltou

10. para mim era a única referencia

11. me sentia presa

12. eu tinha que melhorar de qualquer jeito

13. eu ia em busca do que eu tinha feito

14. as séries nos treinos mostravam que eu estava melhor

15. mas chegava na competição

16. era sempre igual, eu me sentia mal

17. eu não conseguia reagir

18. era sempre difícil

19. na hora ficava tudo automático

20. que doidera

21. dava uma fraqueza

22. eu achava que não ia fazer o que eu já tinha feito

23. me desanimava

24. quase sempre chorava

25. é difícil perceber que as coisas acontecem com a gente

26. agente nem percebe

27. agora consigo perceber

28. eu estava presa naquela situação lá longe

29. em várias

30. eu só ficava pensando naquela lá

31. que ódio

32. burra

33. agora é como se fosse a primeira

34. desencano logo depois que nadei

35. vou para competir

36. acho que consegui isolar

37. demorou

38. eu estou cem por cento

39. nem tática de prova eu levo das outras

40. tudo novo

41. me preparo para cada competição diferente

42. é cada momento

43. sem angústia
Falas, sentidos e categorias

A Liberdade da fala, da escuta e do entendimento

O reordenamento dos sentidos aparecem nesse quadro de forma mais evidente. A nadadora foi desvelando os sentidos e reordenando os significados. De forma resumida mostra os pontos mais marcantes do processo conclusivo. A expansão das categorias se fizeram necessárias para a cooptação de sentidos reordenado e reelaborados

1 - A projeção para o passado

As frases 2, 6, 8, 13, 28, 29 e 30 denotam referência ao passado. A frase número 28 evidencia o movimento psicológico de tentativa de permanência e/or retorno à situação prazerosa.

\section{2 - $A$ ansiedade}

A frase 63 mostra que altos niveis de ansiedade podem bloquear a relação consciente das ações. Essas situação levam às atuações automatizadas. 3-O automatismo

A citação 19 marca de forma clara o automatismo. Recorrente, sempre esteve presente nas entrevistas psicológicas.

\section{4 - Frustração e auto-estima}

As frases $9,15,16,18,24,31,32,51,66,68$ e 72 mostram situações de frustração e baixa-estima principalmente nas frases 24 e 32 respectivamente. Situações de frustração e baixaestima podem desencadear processos depressivos.

\section{5 - Aspectos psicossomáticos}

As frases $21,44,46,47,48,50,54,56,60,70$, 71,76 e 77 mostram que os aspectos psicossomáticos estão associados às sensações corporais. A sensibilidade é importante para os aspectos técnicos da locomoção aquática natatória. O nadador deve estar em sintonia com o ambiente aquático para melhor tracionar. Estados elevados de ansiedade podem alterar aspectos técnicos importantes do gesto motor. A frase 56 relaciona-se com o processo de visualização. Essa técnica visa uma preparação psicológica antecipada das ações. Alterações somáticas podem ser observadas nesse processo de preparação psicológica competitiva. Por exemplo, alteração no ritmo cardíaco podem ser verificadas nesse procedimento. 
QUADRO 10 - Exemplos de dados significativos das entrevistas psicológicas referentes à compreensão de todo o processo de intervenção. (continuação)

\begin{tabular}{|c|c|}
\hline Falas significativas & Falas, sentidos e categorias \\
\hline $\begin{array}{l}\text { 44. mais leve, bem mais leve } \\
\text { 45. ansiedade sob controle } \\
\text { 46. respiro melhor } \\
\text { 47. sem aperto no peito } \\
\text { 48. eu consigo sentir a prova de um jeito melhor } \\
\text { 49. é muito bom } \\
\text { 50. agora eu sinto a água } \\
\text { 51. acho que agora eu estou acreditando mais } \\
\text { 52. eu me lembro bem de cada braçada da } \\
\text { prova } \\
\text { 53. estou nela o tempo todo } \\
\text { 54. mas quando a gente está nadando bem } \\
\text { dentro da prova a gente não sente dor } \\
\text { 55. eu me imagino na competição nadando bem } \\
\text { 56. dá até para sentir a prova antes } \\
\text { 57. passo um filme } \\
\text { 58. começo a nadar antes do tiro } \\
\text { 59. já saio no ritmo } \\
\text { 60. sinto o meu estilo melhor } \\
\text { 61. é só imaginar antes que fica mais fácil } \\
\text { 62. dá mais segurança e força } \\
\text { 63. antes não lembrava de nada } \\
\text { 64. nunca percebi isso } \\
\text { 65. porque } \\
\text { 66. é tudo muito louco } \\
\text { 67. to legal } \\
\text { 68. até a facu (faculdade) melhorou } \\
\text { 69. to noutra } \\
\text { 70. a minha alimentação melhorou } \\
\text { 71. não conseguia manter o peso } \\
\text { 72. tem tudo haver } \\
\text { 73. estou mais leve não só no peso } \\
\text { 74. consigo dormir legal } \\
\text { 75. acordo descansada } \\
\text { 76. minha força melhorou } \\
\text { 77. nunca percebi nada } \\
\text { 78. demorou para entender tudo isso } \\
\text { a }\end{array}$ & 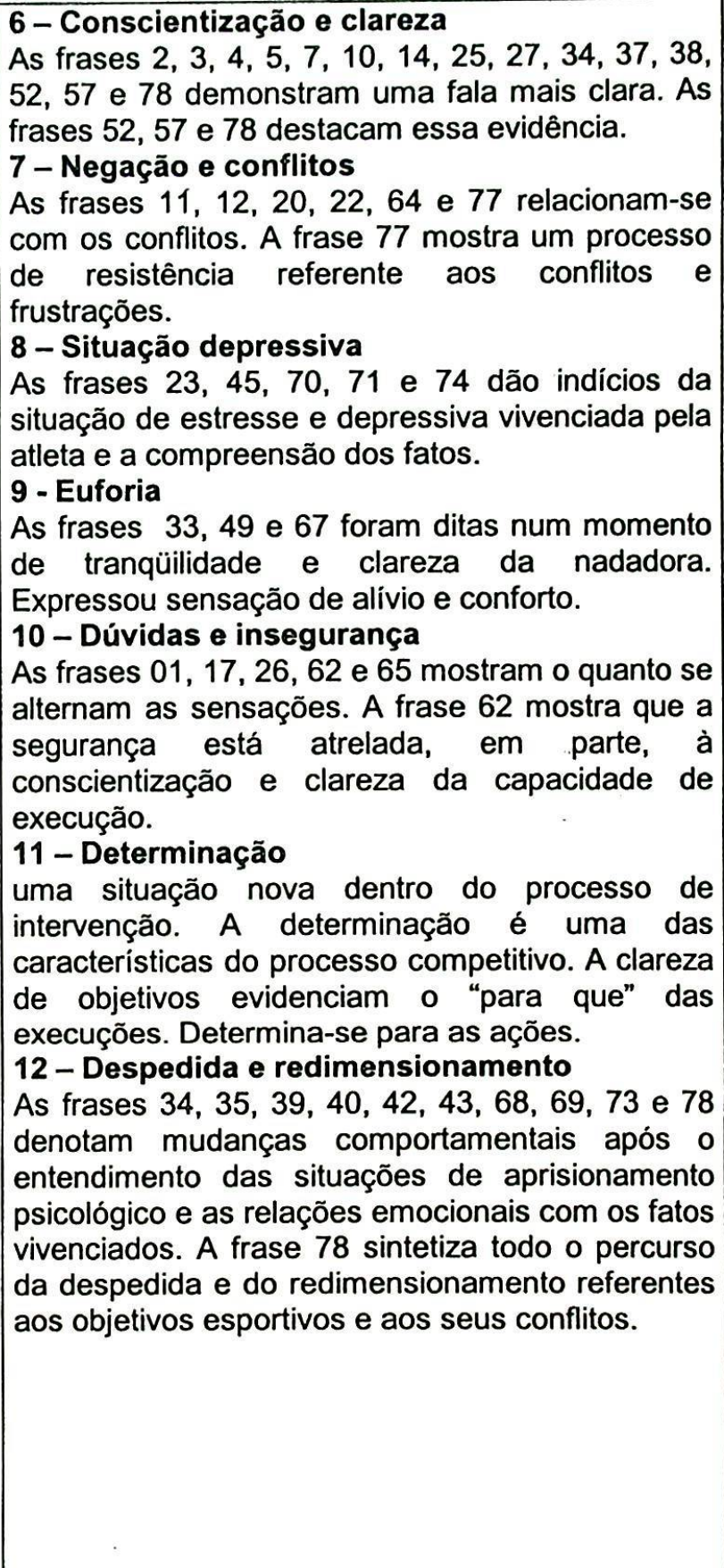 \\
\hline
\end{tabular}




\section{PERSPECTIVAS CONCLUSIVAS}

O presente trabalho parte nas suas perspectivas conclusivas iniciais observando algumas das palavras de FENICHELL (1998, p. 3). Ao dizer que: "...quanto à influência do ambiente, este deve ser investigado em por menor, em sua prática...; não existe "psicologia do homem" em sentido geral, num vazio, por assim dizer; o que existe é uma psicologia do homem em certa sociedade concreta e em certo lugar social dentro desta...e que certamente não são só as frustrações e as reações às frustrações que são socialmente determinadas; o que um ser humano deseja é também determinado pelo seu ambiente cultural..." o autor provoca uma reflexão sobre a necessidade de um olhar ampliado quando se tenta compreender as razões e motivos que levam determinada pessoa agir de uma certa forma. Embora a psicologia no campo esportivo tenha um propósito voltado às performances, não se pode ignorar o atleta esta inserido num sistema social composto por várias nuanças.

Análises preliminares mostravam, nos seus primeiros momentos, que os conteúdos emocionais contidos nas questões vivenciadas pela atleta surgiriam de forma significativa e que esses mesmos conteúdos não se ateriam e tão somente às questões esportivas. As primeiras entrevistas já se caracterizaram como um processo de intervenção. Isso comprova a relevância do papel da psicologia no campo esportivo, com meio investigativo das questões evidentes, num primeiro momento, que interferem negativamente nas performances esportivas. Essas questões do campo esportivo podem coabitar com questões mais profundas, quase sempre não tão claras.

O ser atleta, embora aparentemente surja como completude, o ser humano pleno é que se configura numa dimensão inimaginável quando se refere às suas possibilidade de ser. Olhar para esse período da existência - atleta - não deve se estreitar somente para as questões pontuais como se o contexto não importasse. Embora os atletas personifiquem o mito do herói ( forte, imbatível, imortal), são, por vezes, tais suas excepcionalidades, figuras frágeis, especiais e delicadas. Possuidores de sensibilidades que os excepcionam, levam aqueles que pretendem compreendê-los, reportarem-se a um também ambiente especial: o mundo esportivo das competições de performances. 
As respostas comportamentais se diferenciam entre os indivíduos assim como os gestos executados. A cada momento pode surgir uma configuração, um sentido, um significado. Isso talvez justifique, psicologicamente, o "re-tornar" aos campos, quadras, pistas e piscinas desses especiais atores. $\mathrm{Na}$ realidade eles nunca retornam. Partem sempre para uma nova configuração das suas existências: o sempre buscar por novas marcas. "Tornam-se" assim, possuidores de novas histórias.

Nesse estudo de caso que permitiu o acompanhamento de um período do seratleta de uma nadadora, mostrou o quanto é possível o re-significar dos sentidos que podem impedir o desenvolvimento e o próprio continuar das práticas esportivas competitivas. Conflitos de objetivos podem ser comuns no ambiente da alta performance, tendo em vista o forte sentido dos mesmos. Os resultados esportivos, permanentemente perseguidos, não e tão somente pelos atletas e treinadores, mas, por todo o entorno envolvido no fenômeno, podem aprisionar a figura principal e impedir os seus desenvolvimentos. Talvez nesses momentos, o papel da psicologia esportiva também se justifique.

A prática esportiva deve compor uma relação saudável entre o atleta, o ambiente e o seu entorno. Essa relação deve permanecer ao longo do seu viver. Seja ela no período de execução máxima de performance, seja ela, principalmente, na manutenção da qualidade da sua saúde.

Com relação à Fenomenologia como embasamento teórico no campo da psicologia esportiva, ela mostrou-se eficaz no que se refere às condutas investigativas, não só das questões pontuais intervenientes às performances do meio esportivo do alto rendimento, mas como uma possibilidade ampliada para o entendimento do ser atleta.

Com referência à proposta da pesquisa que busca uma questão pontual relacionada aos conflitos de objetivos esportivos, os preceitos teóricos da Psicologia Existencial Fenomenológica mostraram-se eficazes no processo investigativo e psicológico-interventivo.

Faz-se necessários entretanto, um aprofundamento das pesquisas nessa proposta teórica no campo da psicologia esportiva, bem como uma ampliação da bibliografia especializada no ambiente esportivo do alto rendimento que discutam 
propostas de intervenções, mediante estudos de casos, conforme propõem DAWAR e HORN (1992) e DALE (1996).

\section{$9 \quad$ Sugestões para estudos futuros}

Seguindo as palavras de CRITELLI (1996, p. 25) de que "não se sai em busca da compreensão de um fenômeno tentando aplicar sobre ele uma mesma resposta já sabida sobre o mesmo", tem-se como sugestão e a esperança que esse estudo de caso motive novas investigações nas questões dos objetivos esportivos uma vez que, em nenhum momento teve-se a pretensão de esgotar o assunto. Entender a alta performance passa necessariamente pela formação e aperfeiçoamento das condutas esportivas. Embora as atenção, invariavelmente, se voltem para às performances máximas, a modalidade natação permite com que indivíduos ainda muito jovens se iniciem em suas práticas competitivas. Muitas das condutas comportamentais e dos aspectos psicológicos que impedem o continuar ou mesmo o despontar dos grandes talentos, talvez residam na iniciação esportiva cujo modelo nem sempre é adequado aos iniciantes. O resultado esportivo, em muito depende de uma formação adequada. As individualidades devem ser observadas de maneira criteriosa, via metodologia científica.

Aí se encaixa a psicologia, como auxiliar nessa trajetória: desde a formação ainda quando criança, à idade adulta, onde as sucessões de experiências parecem respaldar as excelências dos grandes resultados esportivos.

$\mathrm{O}$ atleta ao atingir um objetivo, seja ele qual for, parece ser-lhe necessário que se despeça, tão logo possivel de tais feitos, sem, contudo, perder a essência dos seus significados existenciais. Compreender que a construção de novos resultados esportivos ocorrem mediante sucessões de experiências vivenciadas, num continnu de propósitos que permitem com que a espiral do ser ascenda e embale o (re)tornar. 


\section{REFERÊNCIAS}

AMATUZZI, M. M. Apontamentos acerca da pesquisa fenomenológica: estudos e psicologia. Campinas, v. 13, n. 1, p. 5-10, 1996.

ANGERAMI-CAMON, V. A. Psicoterapia fenomenológico-existencial, São Paulo: Ed. Pioneira, 2002.

ARNHEIM, D. \& PRENTICE, W.E. Princípios de treinamento atlético. Rio de Janeiro: Guanabara Koogan, 2002.

BAILLIE, P.H.F. \& DANISH, S. J. Understanding the career transition of athletes. The Sport Psychologist. Champaign, v. 6, n. 1, p. 77-98, 1992.

BANDURA, A. Social learning theory. Englewood Cliffs, NJ: Prentice-Hall, 1977.

. Social foundation of thought and action: a social cognitive theory. NJ, Englewood Cliffs: Prentice-Hall, 1986.

. Perceived self-efficacy in the exercise of personal agency. Journal of Applied Sport Psychology. Champaign, v. 50, n. 1, p. 154, 1990.

BANDURA, A. \& CERVONE, D. Self-evaluation and self-efficacy mechanisms governing the motivational effects of goal systems. Journal of Personality and Social Psychology, v. 45, n.8, p. 1017-1025,1983.

BARBANTI, J. V. Teoria e prática do treinamento desportivo. São Paulo: Edgard Blücher, $2^{\mathrm{a}}$. Ed., 1983.

BICUDO, M. A. V. A contribuição da fenomenologia à educação. In: COELHO, I. M., GARNICA, A.V. M., BICUDO, M. A. V. \& CAPPELLETTI, I. F. Fenomenologia: uma visão abrangente da educação. São Paulo: Olho d'água, 1999, p. 11-51. 
BIDDLE, S. J. H., MARKLAND, D., GILBOURNE, D., CHATZISARANTIS, N. L. D., \& SPARKES, A. C. Research methods in sport and exercise psychology: Quantitative and qualitative issues. Journal of Sports Sciences. Champaign, v. 19, n. 6, p. 777809, 2001.

BLEGER, J. Temas de Psicologia: entrevista e grupos. São Paulo: Martins Fontes, 1980.

BORDINI, M. G. Fenomenologia e Teoria Literária. SP, EUSP, 1990, p. 54.

BRUSTTAD, B.J. Integration socialization influences into the study of children's motivation. Journal of sport and exercise psychology. Champaign, v. 14, n. 1, p. 59-77, 1992.

BUCETA, J. M. La intervención conductual en lo deporte de competición: Aprendizaje-eliminación de comportamientos técnicos y Preparación de la competición. In: G. Buela y V. E. Caballo (eds.) Manual de psicología Clínica Aplicada. Madrid: Siglo XXI, 1991, cap. 4.

. Intervención psicologica em deportes de equipe. Revista de Psicologia General y Aplicada. Madrid, v. 48, n. 1, 1995.

. Psicologia del entranamiento deportivo. Madrid: Editorial Dykinson, 1998.

BURTON, D. Goal setting: a secret to success. Swimming World p. 25-29, fev. 1984.

CARVALHO, A. S. Medotologia da Entrevista: uma abordagem fenomenológica. 2. ed. Rio de Janeiro: Agir, 1991, p. 16. 
CERRONE, D.; JIWANI, N. \& WOOD, R. Goal setting and the differential influence of self-regulatory process on complex decision making performance. Journal of Personality and Social Psychology, v. 61, n. 2, p. 257-266 1991.

CHASE, M., LIRGG, C. \& FELTZ, D. Do coaches's efficacy expectations for their teams performance? The Sport Psychologist. Champaign, v. 11, n. 1, p. 8-23, 1997.

COUNSILMAN, J.E. Competitive swimming manual for choaches and swimmers. Indiana: Counsilman, 1977.

CRATTY, B. J. Psicologia no Esporte. 2 ed. Rio de Janeiro: Prentice-Hall do Brasil, 1984.

CRITELLI, D. M. Analítica do sentido: uma aproximação e interpretação do real de orientação fenomenológica. São Paulo: EDUC: Brasiliense, 1996.

CULVER, D. M., GILBERT, W. D., \& TRUDEL, P. A decade of qualitative research in sport psychology journal: 1990-1999. The Sport Psychologist, Champagn, v. 17, n. 1, p. 1-15 2003.

CRUZ, J. F. Um modelo de investigação e intervenção psicológica na alta competição. Braga: Universidade do Minho, 1996.

DABROWSKI, K. Multilevelness of emotional and instinctive functions. Lublin: Towarzystwo Naukowe. Katolickiego Uniwersytetu Lubelskiego, 1996.

DALE, G. Existencial Phenomenology: Emphasizing the Experience of the Athlete in Sport Psychology Research. The Sport Psychologist, Champaign, v.10, n. 2, p. 307-321, 1986. 
DANISH, E. J., PETIPAS, A. J. \& HALE, B. D. Live development interventions for athletes: Life skills through sports. The Counseling Psychologist. Champaign, v. 21, n. 2, p. 352-358, 1993.

DAWAR, A. \& HORN, T. A critical analysis of knowledge construction in sport psychology. In T. Horn (Ed.), Advances in sport psychology. Champaign. IL.: Human Kinetics Publishers, 1992, p. 13-22.

DE ROSE JÚNIOR, D. Considerações sobre a participação da criança no processo competitivo. In: Simpósio de Psicologia do Esporte, 1992, São Paulo. Anais... São Paulo: EFE/EEFE, 1992. p. 26-33.

DREHER, M. Qualitative research methods from the reviewer's perspective. In J. M. Morse (Ed.), Critical issues in qualitative research methods. Thousand Oaks, CA: Sage, 1994, p. 281-297

EARLEY, C. \& LITUCHY, T. Delineating goal and efficacy effects: a test of three models. Journal of Applied Psychology. Champaign, v. 76, n. 1, p. 81-98, 1991.

ELLITT, B. \& MESTER, J. Treinamento no esporte: aplicando ciência no esporte. Guarulhos, Phorte Editora, 2000.

EPIPHANIO, E. H. Psicologia do esporte e desenvolvimento humano: um estudo exploratório junto a uma equipe feminina de vôlei. 2001. Tese (Doutorado) - Instituto de Psicologia, Universidade de São Paulo, São Paulo.

ERIKSON, E. Childhood and society. New York: Norton, 1950.

. Identidade e Crise. Rio de Janeiro: Zahar, 1972.

FADIMAN, J. \& FRAGER, R. Teoria da personalidade. São Paulo: Harbra, 1986. 
FEIJO, O. G. Psicologia para o esporte: corpo \& movimento. 2. ed. Rio de Janeiro: Shape, 1998.

FEIJOO, A. M. L. C. A psicoterapia em uma perspectiva fenomenológico-existencial. In: Valdemar Augusto Angerami-Camon (organizador) Psicoterapia fenomenológico-existencial.. São Paulo: Pioneira Thomson Learning, 2002, p. 131.

FENICHEL, O. Teoria psicanalítica das neuroses: fundamentos e bases da doutrina psicanalítica. São Paulo: Atheneu, 1998, p. 3

FERREIRA, A.B.H. Novo Dicionário Aurélio Séc. XXI: versão eletrônica 3.0. São Paulo: Nova Fronteira, 1998.

FINA. Federation Internationale de Natatio: rules \& Regulations: 2002-2005. Disponivel em:<http://www.fina.org> Acesso em: 02.abr.2003.

FORGHIERI, Y. C. Psicologia Fenomenológica: fundamentos, método e pesquisas. São Paulo: Pioneira, 1997.

FRAGATA, J. Problemas da fenomenologia de Husserl. Braga: Livraria Cruz, 1962.

FRANÇA, C. Psicologia fenomenológica: uma das maneira de fazer. Campinas: Unicampe, 1989, p. 39

GARRET, A. A entrevista, seus princípios e métodos. 5. ed. Rio de Janeiro: Agir, 1967.

GILBERT, W. D., TRUDEL, P., \& HAUGHIAN, L. Interative decision making factors considered by coaches of youth ice hockey during games. Journal of Teaching in Physical Education. Champaign, v. 18, n. 2, p. 290-311, 1999. 
GIORGI, A. Phenomenology and Psychological Research. Pittsburg: Duquesne University Press, 1985.

. A Phenomenological Perspective on Certain Qualitative Research Methods. Journal of Phenomenological Psychology, Boston, v. 25, no. 2, p. 190-220, 1994.

GOULD, D. Estabelecimento de metas para el maximo rendimiento. In: J. Williams (Ed.), Psicologia Aplicada al Deporte, Madrid: Biblioteca Nueva, 1991, cap. 10.

GOULD, D. \& EKLUND, R. The application of sport psychology for performance optimizions. Journal of Sport Science. Champaign: v. 1, n. 1, p. 10-21 1991.

GOMES, W. B. O Eidético e o Empírico na Psicologia Fenomenológica: Estudos de Psicologia. Campinas, no. 2 e 3, ago/dez, 1985.

. O Critério Metodológico da Fenomenologia Estrutural na Análise de Depoimentos. Psicologia, Reflexão e Crítica, 4(1/2), 1989, p. 98-102.

. Fenomenologia e Pesquisa em Psicologia. Porto Alegre: Ed. Universidade/UFRGS, 1998, p. 22, 31.

GORBUNOV, G.D. Psicologia del deporte. Moscou: VIPO, 1988.

GRANEL L, J. C., CERVERA, V. R. Teoria e planejamento do treinamento desportivo. In: Aproximação à Teoria do Treinamento Desportivo. São Paulo: Artmed, 2003, cap. 1.

HACKFORT, D. \& SPIELBERGER, C. Anxiety in sports: an international perspective. The series in health psychology an behavioral medicine. Edited by Dieter Hachfort and Charles D. Speilberger, 1989. (LOCAL???) 
HAMILTON, G. Teoria e Prática do Serviço Social de Casos. RJ: Agir, 5a. ed., 1982.

HARDY, L. A catastrophe model of performance in sport. In J. Jones and L. Hardy (Eds.), Stress and performance in sport. New York: John Wiley \& Sons, 1990.

HOLANDA, A. F. Pesquisa Fenomenológica e Psicologia Eidética: Elementos para um Entendimento Metodológico. In: Maria Alves de Toledo Bruns \& Adriano Furtado Holenda (Org.), Psicologia e pesquisa fenomenológica: reflexão e perspectivas, São Paulo: Ômega, 2001, p. 36, 41.

HORN, T. S. La teoria de la profecia autocumplida: cuando las expectativas del entrenador se hacen realidad. In: Jean M. Williams, Psicología Apicada al Deporte, cap. V. Ed. Biblioteca Nueva, Madrid, 1991, p. 108-129.

LAPLANCHE, J. Vocabulário da Psicanálise/laplanche e pontalis. São Paulo: Martins Fontes, 1991, p. 89.

LAZARUS, R. S. How emotions influence performance in competitive sports. The sport Psychologist. Champaign, v. 14, n. 2, p. 229-252, 2000.

LESYK, J. J. Developing sport psychology within your clinical practice: a pratical guide for mental health professionals. São Francisco: Jossey-Bass Inc, 1998.

LOCKE, E. A. Problems with goal-setting research in sports and their solution. Journal of Sport \& Exercise Psychology. Champaign, v. 8, n. 2, 311-316,1991.

LOCKE, E. A.; FREDERICK, E.; LEE, C. \& BOBCO, P. Effect of self efficacy, goals and task strategies on task performance. Journal of Applied Psychology. Champaign, v. 69, n. 2, 241-251, 1984. 
LOCKE, E. A.; LATHAM, G. L. The application of goal setting to sport. Journal of Sport Psychology. Champaign, v. 7, n. 2, p. 205-222, 1985.

MCPHERSON, B.D.; CURTIS, J.E.; LOY, J.W. The social significance of sport: an introduction to the sociology of sport. Champaign, IL, Human Kinetics, 1989.

MAGLISCHO, E. W. Swimming even faster. California: Mayfield,1993.

. Swimming fastest. Champaing: Mayfield, 2003.

MALINA, R. Competitive youth sports and biological maturation. In: E.V. Brown and C.F. Banta (ed). Competitive sport for children and youth: an overview of research and issues. Champaign,IL: Human Kinetics, 1988, p. 227-245

MARTENS, R. Science, knowledge, and sport psychology. The Sport Psychologist. Champaign, v.1, n. 1, p. 20-55, 1987.

MARTENS, R., CHRISTINA, R. W.; HARVEY, J. S. JR.; SHARLEY, B. J. Coaching Young Athletes. Champaign, IL: Human Kinetics, 1981.

MARTENS, R.; VEALEY, R.; BURTON, D. Competitive anxiety in sport. Champaign, IL: Human Kinetics, 1990.

MATVÉEV, L. Fundamentos del entreinamiento desportivo. URSS: Ed. Ráguda, 1983.

MAY, R. Psicologia Existencial. Porto Alegre, Ed. Globo, 1976.

NAVARRO, F.; ARELLANO, R.; CARNERO, C.; GOSÁlVEZ, M. Natacion. Madrid: Comitê Olimpico Español, 1990.

OKUMA, S. S. O idoso e atividade física. Campinas: Papirus, 1998, p. 25. 
OLBRECHT, J. The science of winning: planning, periodization and optimizing swim training. Luton: Swimshop, 2000.

PEREIRA, J.C.R. Análise de dados qualitativos: estratégias metodológicas para as ciências da saúde, humanas e sociais. São Paulo, 3. ed, ed. EDUSP, 2001.

PLATONOV, V.N.; FESSENKO, S.L. Los Sistemas de entrenamiento de los mejores nadadores del mundo. Barcelona: Paidotribo, 1994, V. 1.

RAPOSO, J. J. B. V. Manual de treinos para a definição de objetivos. FPN (Federação Portuguesa de Natação). Vila Real: UTAD, 1994.

ROSENTHAL, R. \& JACBSON, L. Pygmalion in the classroom: teacher expectations and pupil's intellectual development. New York: Holt, Rinehart \& Winston, 1968.

RUNKEL, P. J. \& McGRANTH, J. E. Research on Human Behavior: a systematic guide do method. New York: Holt, Rinehart and Winston, 1972.

SCHLOSSBERG, N. K. A model for analyzing human adaptation to transition. The Counseling Psychologist, Champaign, v. 9, n. 1, p. 2-18, 1981.

SIMÕES, A. C. \& DE ROSE JÚNIOR, D. Psicosociologia aplicada ao esporte: contribuição para a sua compreensão. Revista Paulista de Educação Física, São Paulo, v. 13, p. 88-94, 1999.

SINCLAIR, D. A. \& ORLICK, T. Positive transition from high-performance sport. The Sport Psychologist. Champaign, v. 7, n. 1, p. 138-150, 1993. 
SOLOMON, G., STRIEGEL, D., ELIOT, J., HEON, S. \& MAAS, J. The self-fulfilling prophecy in college basketball: Implications for effective coaching. Journal of Applied Sport Psychology. Champaign, v. 8, n. 1, p. 44-59, 1996.

SMITH, D. J.; NORRIS S. R.; HOGG, J. M. Performance Evaluation of Swimmers. International Journal of Sport Medicine, New York, v. 32, n. 9, p. 199-204, 2002.

SMITH, R.E. Toward a cognitive-affective model of athletic burnout. Journal of Sport Psychology. Champaign, v. 8, n. 1, p. 36-50, 1986. . The logic and design of case study research. The Sport Psychologist, 2, 1988, p.1-12

STAMBULOVA, N. B. Developmental sport career investigations in Russia: a postperestroika analysis. The Sport Psychologist, Champaign, v. 8., n. 3, p. 221-237, 1994

. Carrer transitions of Russian athletes. In R. Vanfraechem-Raway \&Y. Vanden Auweele (Eds.), Proceeding of the IX European Congress on Sport Psychology, Brussels: [s.n.], 1995, p. 867-872.

- Athletes's crises: a developmental perspective. Journal of Sport Psychology, Champaign, v. 31, n. 4, p. 584-601, 2000.

TAYLOR, J. \& OGILVIE, B. C. A conceptual model of adaptation to retirement among athletes. Journal of Applied Sport Psychology. Champaign, v. 6, n. 1, p. 1-20, 1994.

TUBINO, M. J. G. Metodologia Científica do Treinamento Desportivo. 2. ed., São Paulo: IBASA, 1979. 
VEALEY, R. Conceptualization of sport-confidence and competitive orientation: Preliminary investigation and instrument development. Journal of Sport Psychology. Champaign, v. 8, p. 221-246, 1986.

. Future directions in psychological skills training. The Sport Psychologist. Champaign, v. 2, p. 318-336, 1988.

. Sport personality: A paradigmatic and methodological analysis. Journal of Sport and Exercise Psychology. Champaign, v. 11, n. 2, p. 216-235, 1989.

. Personality in sport: a comprehensive view. In T. Horn (Ed.), Advances in Sport Psychology. Champaign, 1992, p. 23-59.

VEALEY, R., KING, M. \& HALLING, S. An introduction to existential phenomenological thought in psychology. In R. V. Halling \& A. S. Halling (Eds), Existential phenomenological perspectives in psychology. New York: Plenum Press, 1989, p. 3-16.

VERKHOSHANSKI, Y. V. Treinamento Desportivo: teoria e metodologia. Porto Alegre: ARTMED, 2001.

WEINBERG, R. S.; GOULD, D. Fundamentos da psicologia do esporte e do exercício. Porto Alegre: Artmed, 2001.

WHELAN, J. P.; MEYERS, A. W. \& DONOVAN, C. Competitive recreational athletes: a multisystemic model. In: MURPHY, S. M. Sport psychology interventions. Champaning: Human Kinetics, 1995. cap. 5.

WILKE, K. \& MADSEN, O. El entrenamiento del nadador juvenil. Buenos Aires: Stadium, 1986.

WILLIAMS, J. M. Psicologia Aplicada al Deporte. Madrid: Biblioteca Nueva, 1991. 
anos

Of. CEP 00205/EEFE/06012005

Parecer CEP - Projeto $n^{\circ} 80$

Prezado Senhor

Pelo presente, inforı o que o Comitê de Ética em Pesquisa da EEFE-USP, em reunião orr nária de 22/12/2004, apreciou o projeto de pesquisa intitulado "Obj:tivos esportivos $e$ os conflitos psicológicos em nadadores de elite: um estudo exploratório fenomenológico como proposta de intervenção - estudo de um caso" sob sua responsabilidade, e considerou-o aprovado.

Atenciosamente,

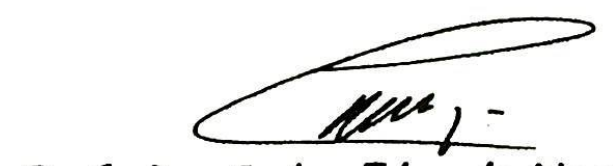

Prof. Dr. Carlos Eduardo Negrão

Presidente do CEP

EEFE-USP

Ilmo. Sr.

Prof. Dr. Dante De Rose Júnior

Departamento de Esporte

EEFE-USP 
ANEXO 2 - Termo de consentimento livre e informado ao atleta

\section{UNIVERSIDADE DE SÃO PAULO Escola de Educação Física e Esporte}

Prezada Atleta

Estamos realizando uma pesquisa para avaliar questões psicológicas relacionadas aos Objetivos Esportivos, que possam interferir negativamente nas performances de atletas da modalidade natação, praticada no alto rendimento, sob orientação do Prof. Dr. Dante de Rose Júnior.

Caso concorde, sua participação consistirá de entrevistas psicológicas esportivas referentes às questões relacionadas aos aspectos psicológicos do seu esporte, acompanhamento dos desempenhos nas sessões de treinamento e principais competições.

Estaremos the oferecendo as devolutivas de forma cuidadosa, bem como a possibilidade, caso do seu interesse, de darmos seqüência às orientações, por mais de uma temporada esportiva anual.

Deixamos claro que será preservada sua identidade e confiabilidade das informações fornecidas e que, a qualquer momento, terás a liberdade de interromper sua participação e retirar-se do estudo, caso assim desejar.

Declaro que, após convenientemente esclarecido pelo pesquisador e ter entendido o que me foi exposto, consinto em participar do presente estudo no campo da psicologia esportiva, bem como a publicação especializada dos dados.

$\mathrm{Em}$ de de 2001.

João Carlos Teixeira de Souza Barros

Psicólogo Pesquisador

CRP- 06/49069-0 - RG - 7874612
Sujeito da Pesquisa

$R G$ - 